\title{
Marine paleoecology of the Eads Mill Member, Hinton Formation, Upper Mississippian, West Virginia and Virginia
}

\author{
Timothy Vance \\ West Virginia University
}

Follow this and additional works at: https://researchrepository.wvu.edu/etd

\section{Recommended Citation}

Vance, Timothy, "Marine paleoecology of the Eads Mill Member, Hinton Formation, Upper Mississippian, West Virginia and Virginia" (2007). Graduate Theses, Dissertations, and Problem Reports. 2545.

https://researchrepository.wvu.edu/etd/2545

This Thesis is protected by copyright and/or related rights. It has been brought to you by the The Research Repository @ WVU with permission from the rights-holder(s). You are free to use this Thesis in any way that is permitted by the copyright and related rights legislation that applies to your use. For other uses you must obtain permission from the rights-holder(s) directly, unless additional rights are indicated by a Creative Commons license in the record and/ or on the work itself. This Thesis has been accepted for inclusion in WVU Graduate Theses, Dissertations, and Problem Reports collection by an authorized administrator of The Research Repository @ WVU. For more information, please contact researchrepository@mail.wvu.edu. 
Marine paleoecology of the Eads Mill Member, Hinton Formation, Upper Mississippian, West Virginia and Virginia

Timothy Vance

Thesis submitted to the Eberly College of Arts and Sciences at West Virginia University in partial fulfillment of the requirements for the degree of

Master of Science in Geology

\author{
Thesis committee: \\ Thomas Kammer, Ph.D. (chair) \\ Richard Smosna, Ph.D. \\ Jack Beuthin, Ph.D. \\ University of Pittsburgh, Johnstown
}

Department of Geology \& Geography

Morgantown, WV

2007

Keywords: Paleoecology, Upper Mississippian, Carboniferous, Hinton Formation, Appalachian Basin 


\section{Abstract \\ Marine paleoecology of the Eads Mill Member, Hinton Formation, Upper Mississippian, West Virginia and Virginia}

\section{Timothy Vance}

During the Late Mississippian, the Eads Mill Member of the upper Hinton Formation was formed during the last marine transgression before deposition of the Princeton Sandstone. Five outcrops extending northward from southwest Virginia into southern West Virginia were sampled, and constituent fossil genera were identified in the lab. Seven guilds were recognized and similar taxa were grouped together based on their morphology and life habits. Binary presence/ absence data were compiled for all guilds at each sampled unit, and processed using four multivariate techniques in order to identify any underlying paleoecological signal. All techniques yielded a strong trend in the data interpreted to represent the salinity tolerances of the taxa within each guild, though other environmental factors such as substrate and turbidity could also have had a minor influence. Lithologic data and multivariate analyses were then combined to understand the changing environmental conditions during the formation of the Eads Mill Member. Both sets of data indicate that the Eads Mill Member was formed by an overall transgressive/ regressive cycle that formed brackish and transitional marine conditions at the base and top of the member, and open marine conditions in the middle represented by two laterally continuous fossiliferous limestones. Multivariate results were compared to those of the underlying Fivemile Member, whose taxa indicated that it was deposited in predominantly brackish marine conditions. These two members were then related to similar taxonomic compositions in the older Bluefield Formation, the Greenbrier Limestone Group, and the Avis Limestone. The results indicate that water salinity and corresponding taxonomic salinity tolerances were the controlling factors on taxonomic diversity of marine units formed in the Appalachian Basin during the Late Mississipian. 


\section{Acknowledgements}

I would like to begin by thanking Dr. Jack Beuthin and Mitch Blake for their willingness to assist in the initial work conducted on this thesis. The initial field area tour by Mitch in November, 2005 presented the overall picture of upper Hinton Formation deposition, and familiarized me with the outcrops and sampling units later to be investigated. Jack’s contribution of stratigraphic section described by himself and Mitch was invaluable. Without the sedimentological work having already been done, this thesis would have taken significantly more time to complete.

I would also like to thank my advisor Dr. Tom Kammer and my fellow research partner Tom Cawthern for their contributions to this work. Dr. Kammer's guidance and instruction provided constant direction and insight which was always useful and sometimes desperately needed. Tom Cawthern's contribution and aide in field research, taxon identification, multivariate analysis, and every other facet of this thesis was beyond compare. Without his help, this thesis would have been a much less enjoyable undertaking, if it would have been conducted at all.

Finally, the constant love, prayer and encouragement of my family, friends and fiancée Amanda have been an invaluable motivation and support for completion of this work. The help of the Lord and so many incredible people along the way made reaching this goal possible. Thank you all. 


\section{Table of Contents}

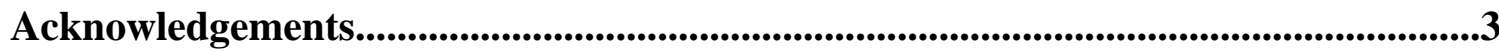

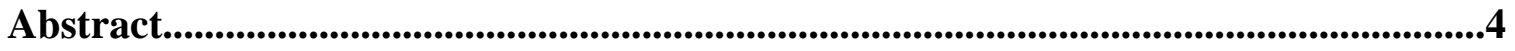

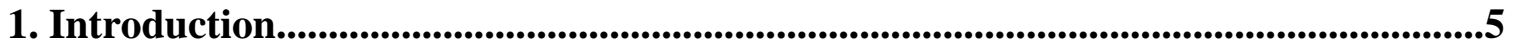

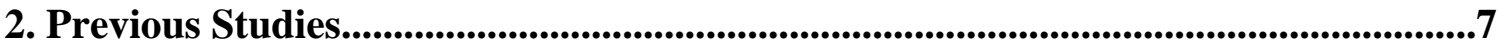

3. Geologic Setting...........................................................................................................10

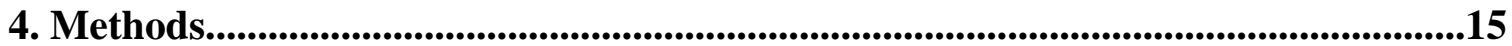

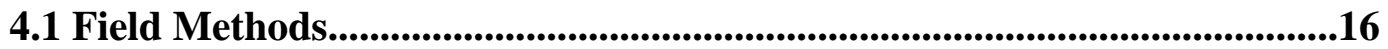

4.2 Laboratory Methods........................................................................................18

4.3 Multivariate Techniques....................................................................18

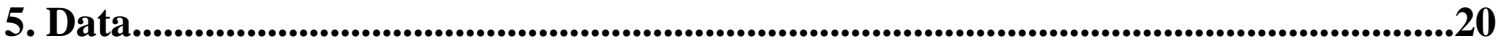

5.1 Outcrop Descriptions

5.1.1 Route 102, Virginia...............................................................................20

5.1.2 Christian Fork Lake.................................................................23

5.1.3 Bluestone River Bridge along Eads Mill Rd...............................24

5.1.4 Pipestem Creek...........................................................................22

5.1.5 Interstate 64........................................................................29

5.2 Invertebrate Fossils............................................................................................33

5.3 Multivariate Matrices and Analyses.............................................................37

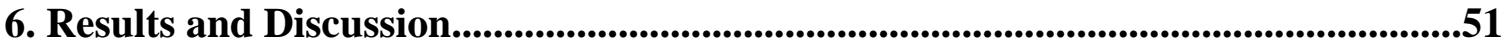

6.1 Stratigraphic Analysis...................................................................................51

6.2 Multivariate Analysis...............................................................................................52

6.3 Eads Mill Member Paleoecology........................................................................53

6.4 Upper Hinton Formation Paleoecology....................................................61

6.5 Synthesis..........................................................................................................................72

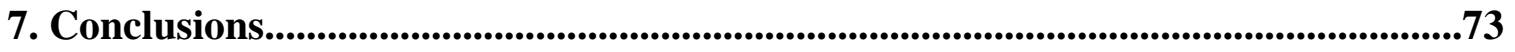

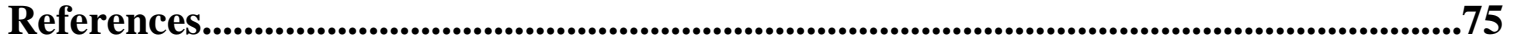

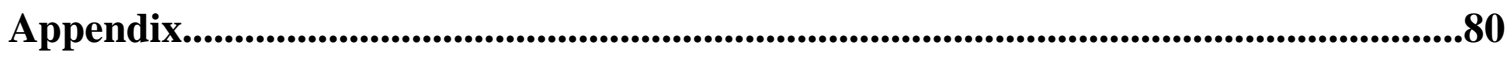




\section{$\underline{\text { Tables }}$}

Table 1. Complete list of all 36 Eads Mill Member genera and 10 taxonomic types.

Table 2. Original binary data set containing all identified fossil genera and sampling intervals.

Table 3. Constituent taxa of 7 constructed guilds.

Table 4. Taxa with two or fewer occurrences that were removed from the data set during the construction of guilds.

Table 5. Outcrop samples and seven guilds constructed from binary count data. Table 6. Binary guild data for the Eads Mill Member (Part 1) and the Fivemile Member (Part 2). 


\section{Figures}

Figure 1. Hinton Formation map illustrating outcrop localities across southern West Virginia and southwestern Virginia.

Figure 2. Mississippian stratigraphic section from nearby Giles Co., VA (McDowell and Schultz, 1990).

Figure 3. Paleogeographic maps showing ocean trend currents and position of the Appalachian Basin (adapted from Smith and Read, 2000).

Figure 4. Stratigraphic chart illustrating previous and current nomenclature for the upper Hinton Formation in southern West Virginia. (Beuthin and Blake, 2004)

Figure 5. Stigmaria plant fossil from the Sample 99 sandstone along Rt. 102, VA.

Figure 6. Stratigraphic column of the Rt. 102 Virginia outcrop showing lithology and taxa.

Figure 7. Stratigraphic column of the Christian Fork Lake outcrop showing lithology and taxa.

Figure 8. Characteristic “toadstool” weathering of the Sample 11 limestone underneath the Bluestone River Bridge. 
Figure 9. Stratigraphic column of the Bluestone River Bridge outcrop showing lithology and taxa.

Figure 10. Close-up of the highly fossiliferous Sample 12 shale at the Bluestone River Bridge.

Figure 11. Stratigraphic column of the Pipestem Creek outcrop showing lithology and taxa.

Figure 12. Eads Mill Member outcrop along the western side of WV Rt. 20 near Pipestem Creek.

Figure 13. Stratigraphic column of the I-64 outcrop showing lithology and taxa.

Figure 14. Correlation diagram through the five described Eads Mill Member sections (Figure 1).

Figure 15. The bivalve Ectogrammysia.

Figure 16. The straight shelled nautiloid Reticycloceras.

Figure 17. Solitary rugose corals. 
Figure 18. The productid brachiopod Ovatia.

Figure 19. Cluster analysis of Eads Mill Member samples containing three or more taxa using the cosine theta coefficient.

Figure 20. Cluster analysis illustrating similarities between guilds based on their salinity tolerances, using the correlation coefficient.

Figure 21. Non-metric MDS analysis showing the distinct separation of samples by salinity tolerance.

Figure 22. Non-metric MDS showing separation of guilds into open marine and marginal marine based on salinity tolerances.

Figure 23. Correspondence analysis illustrating the relationships between Eads Mill samples and guilds.

Figure 24. Detrended correspondence analysis (DCA1) of the Eads Mill Member's Q-mode data (Table 5).

Figure 25. Stratigraphic patterns in DCA1 scores for the most complete Eads Mill Member outcrops using sample scores on Axis 1 of detrended correspondence analysis (DCA1). 
Figure 26. Combined detrended correspondence analysis (DCA1) sample score graphs from Figure 25 for the Eads Mill Member.

Figure 27. Cluster analysis combining the Fivemile and Eads Mill Members' Qmode binary data (Table 5) using the Jaccard coefficient.

Figure 28. Cluster analysis combining the Fivemile and Eads Mill Members' Rmode binary guild data (Table 5).

Figure 29. Non-metric MDS chart combining the Fivemile and Eads Mill Members' R-mode data (Table 5).

Figure 30. Detrended correspondence analysis (DCA1) of the Fivemile and Eads Mill Members’ Q-mode data (Table 5).

Figure 31. Detrended correspondence analysis (DCA1) of the Fivemile and Eads Mill Members' R-mode data (Table 5).

Figure 32. Bar graph illustrating the distribution of the 12 guilds in both the Fivemile and Eads Mill Members based on their Axis 1 detrended correspondence analysis (DCA1) scores. 
Figure 33. Chart showing stacked Fivemile and Eads Mill Member DCA1 sample scores. 


\section{Introduction}

The current study is a paleoecological analysis of the Late Chesterian (c. $325 \mathrm{Ma}$ ) age Eads Mill Member of the Hinton Formation (Beuthin and Blake, 2004). It includes

five outcrops located in southern West Virginia and southwestern Virginia (Figure 1). The outcrops extend from near Bluefield, VA along Rt. 102 to Princeton, WV, and up to near Green Sulfur Springs, WV along I-64. This outcrop selection closely follows the available outcrops of the Eads Mill Member that contain marine fossils.

The purpose of this research is to identify and analyze the diverse marine invertebrate faunas in the Eads Mill Member of the Hinton Formation contained within four outcrops in southern West Virginia and one in Virginia. Information derived from identification of taxa and use of multivariate techniques to interpret patterns in the data helped construct a paleoecological interpretation. While previous studies have addressed other fossil assemblages in Upper Mississippian strata, such as those in the underlying Bluefield Formation (Kammer and Lake, 2001), this is the first study to specifically analyze the Eads Mill Member. Because the Hinton Formation is dominated by paleosols and other non-marine deposits, the fossils contained within this member permit a glimpse of one of the youngest marine faunal assemblages present in the Mississippian system of the Appalachian Basin before the Pennsylvanian Period (Beuthin and Blake, 2004).

The goal of this research is to integrate this paleoecologic study into previous information on the upper Hinton Formation. After reconstructing the paleoenvironment 
that formed the Eads Mill Member, the results of the current study should be combined with other studies on eustatic, climatic, and glacial processes present during the Late Mississippian. In doing so, this will yield a more complete and thorough understanding of the global conditions and depositional processes responsible for the formation of rocks during the Late Chesterian in the Appalachian Basin.

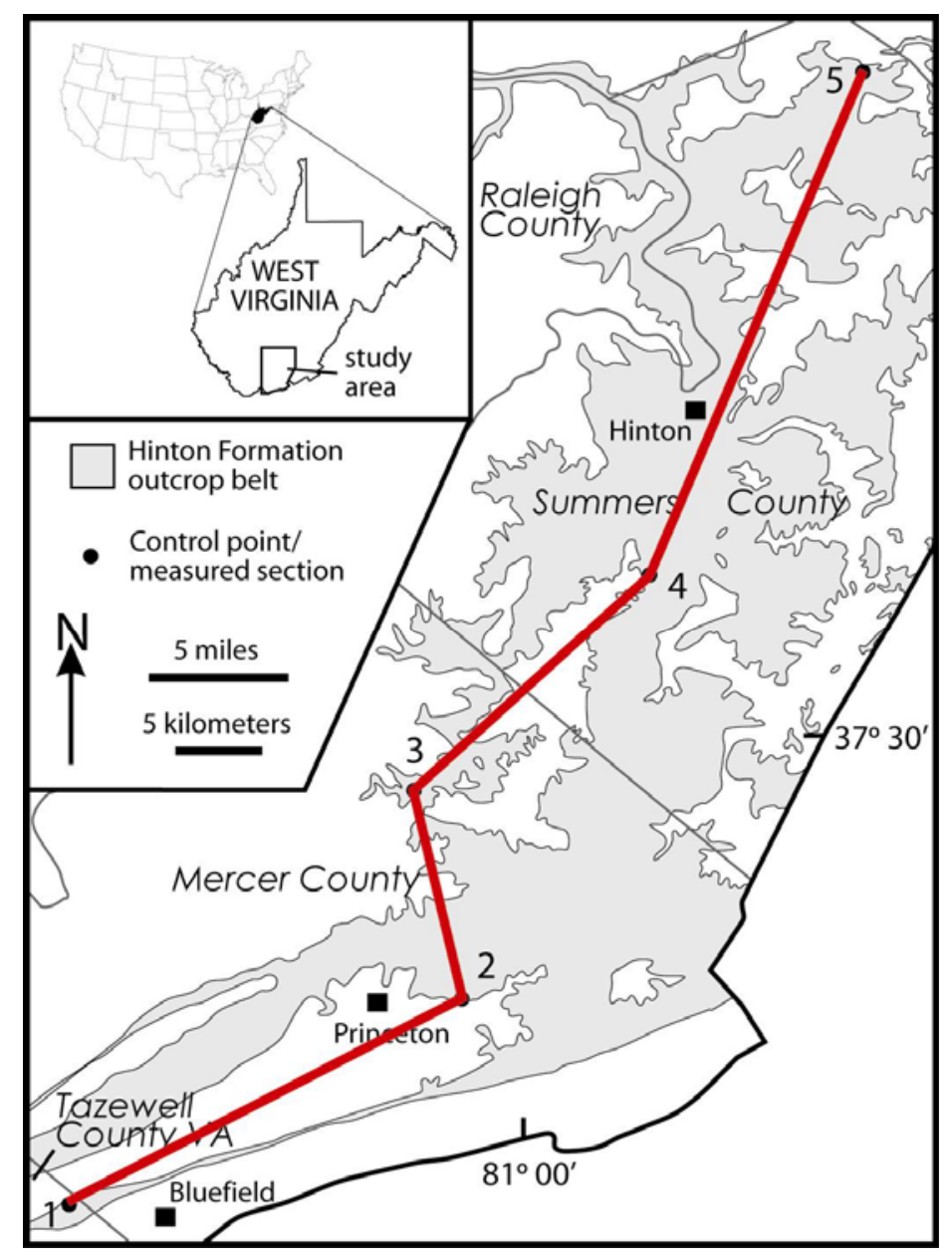

Figure 1. Hinton Formation map illustrating outcrop localities across southern West Virginia and southwestern Virginia. Outcrops beginning in the south are: (1) Route 102 VA: UTM 17N 0474845 W 4124495, (2)Christian Fork Lake: UTM 17N 0496405 W 4135323, (3) Bluestone River Bridge: UTM 17N 0493470 W 4147784, (4) Pipestem: UTM 17N 0503534 W 4155548, (5) I-64 above Green Sulfur Springs: UTM 17N 0520041 W 4187292. (Beuthin and Blake, 2004) 


\section{Previous Studies}

The Hinton Formation is a northwest thinning wedge of marine and non-marine rocks that crop out in southern West Virginia and southwestern Virginia. The upper Hinton Formation, which can be up to 150 meters thick, is characterized by paleosols, thin impure coals, fluvial facies, and other non-marine deposits that grade upwards into thin shales and marine limestones that mark the maximum extent of transgression (Beuthin and Blake, 2004). Previous studies of the Hinton Formation and correlative aged formations in the mid-continent have focused on interpreting the rock strata in order to construct a climate-influenced depositional model. Such studies have investigated the significance of paleosols (Miller and Eriksson, 1999, 2000), and the increasing abundance of coal (Englund et al., 1986). The occurrence of incised valley fills that may have been controlled by the expansion and contraction of glacial ice during the Late Mississippian have also been studied (Smith and Read, 2000, 2001). However, these studies focused primarily on stratigraphic interpretation and did not conduct as complete of a paleontological assessment as was accomplished during this study.

The West Virginian Avis Limestone of Reger (1926), or the correlative Little Stone Gap Member described in Virginia and Kentucky, is the only marine zone previously studied within the Hinton Formation (Figure 2). The Avis Limestone, which is the basal unit of the upper Hinton Formation (Beuthin and Blake, 2004) is composed of calcareous mudstones and shales, with some interbedded pure limestone (Miller, 1964). It contains a diverse marine fauna dominated by brachiopods and bryozoans, as well as 
bivalves, corals, and crinoids (Henry and Gordon, 1992), which indicates that the Avis Limestone was deposited in a stenohaline, open marine environment.

Other marine invertebrate faunas of the Mauch Chunk Group have been described from both the underlying Bluefield Formation and the overlying Bluestone Formation (Figure 2). Kammer and Lake (2001) described faunas contained within the Bickett Shale and the Reynolds Limestone members of the Bluefield Formation in northern West Virginia. The Bickett Shale contained euryhaline taxa such as the gastropod Bellerophon and many genera of bivalves such as Ectogrammysia and Phestia. They interpreted the Bickett Shale as having formed in bays or estuaries during a period of regression. The Reynolds Limestone represented a stenohaline, open marine fauna consisting of abundant brachiopod genera such as Anthracospirifer, Composita, and Diaphragmus, along with fenestrate bryozoans, crinoids and solitary rugose corals.

Above the Hinton Formation, two marine zones in the Bluestone Formation have also been described in the Pride Shale Member and the Bramwell Member. The Pride Shale, which sits atop the Princeton Sandstone is composed of dark gray, silty shale with some lenses of siderite nodules. Plant fossils and bioturbation are common, but some zones contain fragmented brachiopod, bivalve, cephalopod and crinoid remains. The Bramwell Member of the Bluestone formation also shows evidence of stenohaline marine conditions by containing the bryozoan Fenestella and the brachiopods Orthotetes and Ovatia (Henry and Gordon, 1992). Many genera of bivalves are also present and many, 
such as Phestia and Aviculopecten, correspond with those found in the underlying Bluefield Formation.

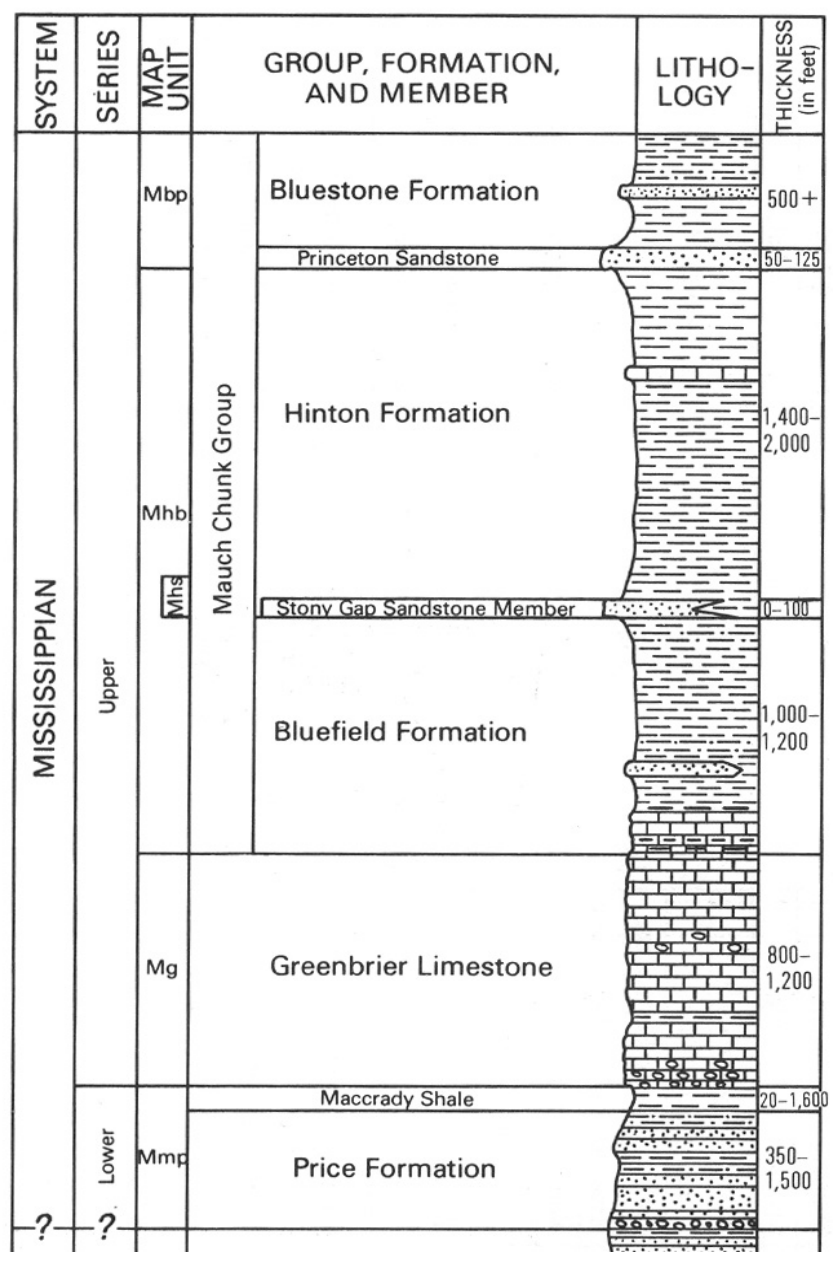

Figure 2. Mississippian stratigraphic section from nearby Giles Co., VA (McDowell and Schultz, 1990). The Eads Mill Member is located directly beneath the Princeton Sandstone at the top of the Hinton Formation. The limestone bed shown in the Hinton Formation is the Avis Limestone Member.

Overall, the Mauch Chunk Group and its constituent formations are considered to be relatively unfossiliferous, but only the most apparent marine units have been sampled to ascertain their faunal composition. However, faunas from the Bluefield and Bluestone Formations indicate that many invertebrate taxa existed throughout the Chesterian, and that their occurrences within the formation were predicated upon tolerance to salinity in 
the depositional environment (Kammer and Lake, 2001). As will be described in detail later in the paper, many of these same taxa previously mentioned also occur in the Eads Mill Member of the Hinton Formation, and suggest similar preferences for salinity and environmental conditions.

\section{Geologic Setting}

Deposition of siliciclastic and carbonate rocks in the Appalachian Basin during the Late Mississippian (Chesterian) was affected by both glacio-eustatically derived sea level fluctuations (Miller and Eriksson, 1999, 2000) and the onset of reactivated tectonism at the beginning of the Alleghanian Orogeny (Ettensohn et al., 2002). Whereas many authors have cited one process with the exclusion of the other as evidence for sequence formation in the Mauch Chunk Group, the author agrees with the postulations of Klein and Kupperman (1992) that $4^{\text {th }}$ and $5^{\text {th }}$ order Milankovitch cycles related to glacio-eustatic fluctuations were formed concurrently with $3^{\text {rd }}$ order and longer tectonically controlled basin subsidence and later isostatic uplift. The following will describe hypothesized controls on sedimentation during the Late Mississippian in the Appalachian Basin, and more specifically how those processes affected both the lithofacies described in the upper Hinton Formation and the constituent faunal assemblages.

The Appalachian foreland basin was located approximately $10-20^{\circ}$ south of the paleoequator during the Late Mississippian (Scotese, 1986). As Laurussia (Figure 3) 
drifted northward during the collisional assembly of Pangea (Miller and Eriksson, 1999, 2000) the climate altered from semi- arid conditions typified by the formation of large numbers of paleosols in the lower Hinton Formation, to the humid conditions encountered in the Early Pennsylvanian (Cecil, 1990).

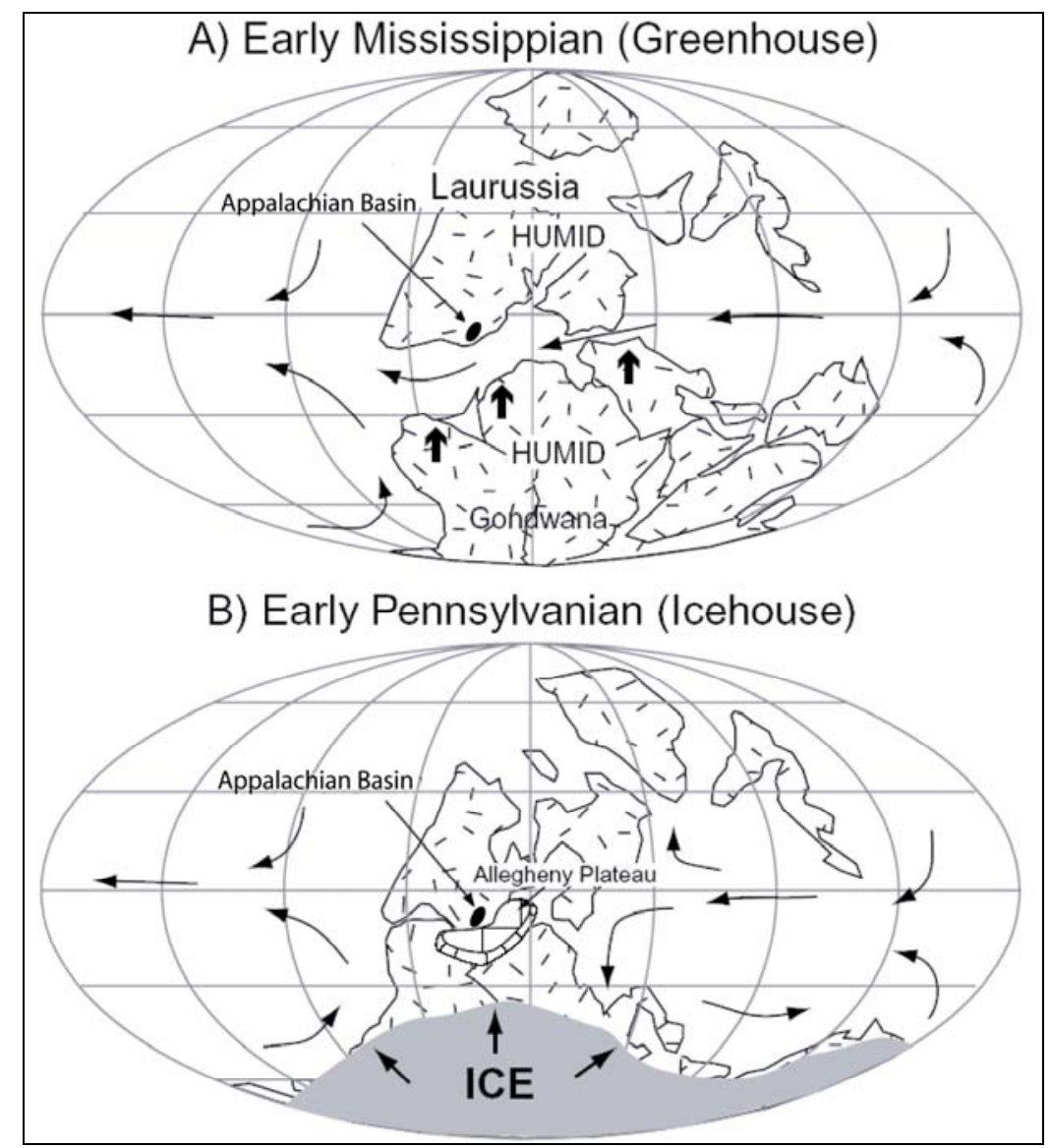

Figure 3. Paleogeographic maps showing ocean trend currents and position of the Appalachian Basin (adapted from Smith and Read, 2000). A: Free flowing ocean currents facilitated open climatic circulation creating humid conditions on the North American plate. B: Closure of the intercontinental seaway diverted ocean flow around Gondwana, initiating the formation of glaciers in the Southern Hemisphere.

Closing of the intercontinental seaway separating Laurussia and Gondwana significantly affected oceanic and atmospheric circulation patterns, as illustrated in Figure 3 (Smith and Read, 2000). This reduced circulation caused continental glaciers to 
periodically form in the southern hemisphere on Gondwana, thereby creating high frequency eustatic sea level fluctuations. The Appalachian Basin was also experiencing a time of isostatic rebound contemporaneous to the formation of glaciers on Gondwana, as the tectonic highlands rebounded after unloading during the Middle Chesterian (Ettensohn et al., 2002). Sediments filling the basin were sourced from the nearby Appalachian tectonic highlands, which experienced a rapid increase in source area size caused by the initiation of isostatic uplift (Brezinski, 1989).

The combined effects of climate and isostatic uplift at the end of the Acadian Orogeny resulted in the formation of the Mauch Chunk siliciclastic wedge. In south West Virginia where the current study took place, this westward tapering wedge of predominantly clastic rocks reaches a maximum thickness of $900 \mathrm{~m}$ (Maynard et al., 2006). The Mauch Chunk Group, which encompasses the Bluefield, Hinton, Princeton, and Bluestone Formations (Figure 2), contains terrestrial facies such as paleosols (Miller and Eriksson, 1999, 2000), fluvial deposits in incised valleys (Smith and Read, 2000, 2001), and a lesser number of thin coal beds (Englund et al., 1986). These lithologies confirm a semi-arid climate with periodically seasonally wet conditions (Cecil, 1990; Beuthin and Blake, 2002).

The upper Hinton Formation as defined by Beuthin and Blake (2004), extends from the top of the Avis Limestone of Reger (1926) to the base of the Princeton Sandstone (Figure 4). It attains a maximum thickness of 150 meters within the study area near Bluefield, VA and thins progressively northward, pinching out before reaching 
northern West Virginia (Beuthin and Blake, 2004). The upper Hinton Formation, of which the Eads Mill is the uppermost member, is characterized by nearshore deposits such as fossiliferous shales and limestones that formed during periods of transgression, as well as paleosols, fluvial sandstones and thin impure coals, which show evidence of terrestrial deposition (Englund et al., 1986; Beuthin and Blake, 2004). This lithologic assemblage has been interpreted as a marginal marine depositional environment, which included estuarine, lagoonal, shoreface and tidal facies (Ettensohn et al., 2002). Climatic conditions during deposition of the upper Hinton Formation were relatively dry and semiarid as shown by terrestrial calcareous red beds (Cecil, 1990; Beuthin and Blake, 2002), although Miller and Eriksson (1999) have pointed to the presence of leached paleosols and thin coals as evidence for more humid climatic conditions. However, the more likely explanation is that these paleosols and coals were deposited in waterlogged topographic lows near the coastline (Greb and Chestnut, 1998, Beuthin and Blake, 2004). Overall, the upper Hinton Formation contains a broad range of facies indicative of dynamic nearshore and coastal depositional environments.

The Eads Mill Member is the uppermost unit of the Hinton Formation (Figure 4) and at some localities is directly overlain by the Princeton Sandstone. It is a distinct marine unit, separated from the underlying Fivemile Member by over 25 meters of terrestrial deposits containing fluvial sandstones, shales, and rooted paleosols. The base of the Eads Mill Member is marked by the abrupt transition from rooted paleosols to fissile marine shales and argillaceous bioclastic limestones. The Eads Mill Member provides an opportunity to study another fully marine biotic assemblage in the upper 
Hinton Formation. Such information can be applied to the previously described faunas within the underlying Bluefield Formation and Avis Limestone, and the younger Pride Shale of the Bluestone Formation, to create a clearer picture of the paleoecological conditions present in the Appalachian Basin during the Late Mississippian.

\begin{tabular}{|c|c|c|c|c|c|}
\hline \multicolumn{3}{|c|}{ This Report } & $\begin{array}{l}\text { Krebs and } \\
\text { Teets, } 1916\end{array}$ & Reger, 1926 & Englund, 1968 \\
\hline \multirow{26}{*}{ 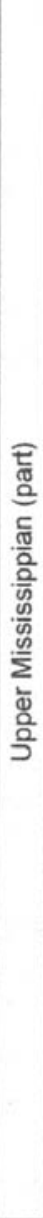 } & \multirow{2}{*}{ 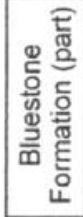 } & undivided & \multirow{2}{*}{$\begin{array}{l}\text { Pluto Coal } \\
\text { undivided }\end{array}$} & $\begin{array}{l}\text { numerous } \\
\text { members }\end{array}$ & $\begin{array}{l}\text { gray and red } \\
\text { members }\end{array}$ \\
\hline & & $\begin{array}{c}\text { Pride Shale } \\
\text { Member }\end{array}$ & & Pride Shale & Pride Shale \\
\hline & \multicolumn{2}{|c|}{ Princeton Formation } & Princeton Sandstone & Princeton Sandstone & Princeton Sandstone \\
\hline & \multirow{21}{*}{ 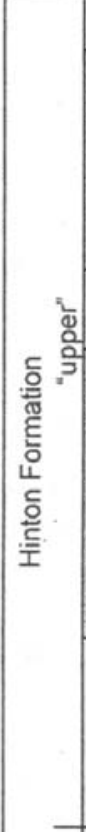 } & undivided & undivided & Terry Shale & \\
\hline & & \multirow{5}{*}{$\begin{array}{l}\text { Eads Mill } \\
\text { Member }\end{array}$} & Terry Limestone & Terry Limestone & \multirow{5}{*}{$\begin{array}{l}\text { upper } \\
\text { shale } \\
\text { member }\end{array}$} \\
\hline & & & & Upper Pluto Shale. & \\
\hline & & & & Pluto coal & \\
\hline & & & & $\begin{array}{l}\text { Pluto Limestone } \\
\text { Lower Pluto Shale }\end{array}$ & \\
\hline & & & & Falls Mills Sandstone & \\
\hline & & \multirow[b]{2}{*}{ undivided } & & & Pratter Shale Member \\
\hline & & & & Falls Mills Shale & Tallery Sandstone \\
\hline & & & \multirow{7}{*}{ undivided } & & \multirow{11}{*}{$\begin{array}{l}\text { middle } \\
\text { shale } \\
\text { member }\end{array}$} \\
\hline & & & & $\begin{array}{l}\text { Falis Mills Limestone } \\
\text { Upper Fivemile Shale }\end{array}$ & \\
\hline & & Fivemile & & Fivemile Coal & \\
\hline & & Member & & Lower Fivemile Shale & \\
\hline & & & & $\begin{array}{l}\text { Tallery Sandstone } \\
\text { Tallery Limestone }\end{array}$ & \\
\hline & & & & Upper Tallery Shale & \\
\hline & & & & Tallery Coal & \\
\hline & & \multirow{6}{*}{ undivided } & & Lower Tallery Shale & \\
\hline & & & & Low Gap Sandstone & \\
\hline & & & & Low Gap Limestone & \\
\hline & & & & Low Gap Shale & \\
\hline & & & & Avis Sandstone & Neal Sandstone \\
\hline & & & & Upper Avis Shale & \multirow{3}{*}{$\begin{array}{l}\text { Little Stone Gap } \\
\text { Member (expanded } \\
\text { from Miller, 1964) }\end{array}$} \\
\hline & \multirow{2}{*}{ 능 } & $\begin{array}{l}\text { Avis Limestone } \\
\text { of Reger (1926) }\end{array}$ & Hinton Limestone & Avis Limestone & \\
\hline & & undivided & undivided & Lower Avis Shaie & \\
\hline
\end{tabular}

Figure 4. Stratigraphic chart illustrating previous and current nomenclature for the upper Hinton Formation in southern West Virginia. (Beuthin and Blake, 2004) 


\section{Methods}

Collecting and analyzing fossil data for this study incorporated multiple field and laboratory methods. An initial tour and evaluation of potential outcrops of the Hinton Formation in southern West Virginia and southwestern Virginia was conducted in early November 2005. When sufficient amounts of fossil material were noted at a number of localities, it was decided that the first week of summer following the end of spring semester would be focused on fossil collection at five outcrops within the southern extent of the outcrop belt. After field collection of individual specimens and large bulk samples to ensure detection of all present taxa, the fossils and samples were transported to the paleontology laboratory at West Virginia University in 303 White Hall, where identification to the genus level for each specimen was conducted. Identification to the genus level was sufficient for paleoecological analysis because differences in life habits between genera are much more significant that those between species (Kammer and Lake, 2001). Once properly identified multivariate analysis of the specimens was conducted using presence/absence data of the fossil taxa. The presence or absence of taxa within each unit is indicative of the environmental conditions present within each sample. By combining sample presence/ absence data with sedimentologic data such as lithology, bedding characteristics, and sedimentary structures, the overall depositional conditions present in each sample and for the entire locality were determined. 


\subsection{Field Methods}

The initial step in the data collection process was a preliminary trip to view the outcrops in early November 2005. The purpose of the trip was to familiarize myself and research partner Tom Cawthern with a number of outcrops containing either or both the Fivemile or Eads Mill lithologic sections. The outcrops ranged from Bluefield, VA to north of Green Sulfur Springs, WV (Figure 1). The group briefly sampled fossiliferous intervals to gain a cursory understanding of the total taxonomic richness and diversity. Collected samples were returned to the lab where they were identified to the genus level and then categorized based on individual outcrops. The result of the weekend was the identification of five productive outcrops that contained multiple, abundantly fossiliferous horizons. The outcrops formed a transect that trended northeast/southwest, approximately following the dip slope of the ancient coastal plain (Jack Beuthin, personal communication, 2006). The five chosen outcrops, from south to north are: Route 102 VA, Christian Fork Lake, Bluestone River Bridge, Pipestem, and I-64 north of Green Sulfur Springs (Figure 1).

Data collection in the field began on Sunday, May 7, 2006 with our operations based out of Camp Creek State Park near Princeton, WV. The outcrops were collected in order from south to north, beginning with Route 102 VA, which contained the thickest section of the Eads Mill and the underlying Fivemile Member. Specimens were obtained both loose, having weathered from the outcrop, and with rock hammers and chisel for those that were still in place. Samples were placed in collection bags and labeled 
according to their outcrop locality, date, and precise stratigraphic position using the measured sections provided by Jack Beuthin and Mitch Blake, which they compiled while conducting research for their 2004 published paper (Appendix 1). Samples collected loose on the surface of each outcrop and those collected in place were initially kept separate to ensure that mixing of samples from different stratigraphic zones did not occur. Bulk samples containing large quantities of fossils were obtained and labeled like the individual specimens. These were later disaggregated in the lab to determine their fossil content.

Thorough fossil collection at each outcrop continued for the remainder of the week. With the help of Tom Cawthern, multiple sample bags for each fossiliferous lithologic zone were collected. Collection of large numbers of specimens was conducted to ensure that the total taxonomic richness of each unit within the outcrop was represented. While the ideal number of 300 or more fossil specimens were not able to be obtained from each sampled unit (Chang, 1967), sufficient quantities of fossils were acquired in a reasonable amount of time to ensure ample taxonomic representation. Collection of all five outcrops was completed by Saturday, May 13, at which time all of the samples were transported back to 303 White Hall for specimen preparation and identification. 


\subsection{Laboratory Methods}

In late June 2006, laboratory identification of the collected specimens began. Those fossils obtained individually in the field that were muddy were washed and allowed to dry. Bulk samples were carefully disaggregated and derived specimens were placed into appropriately labeled collection bags. Fossils were identified by each unit per outcrop using microscopes, hand lenses and reference materials in order to correctly identify each to the genus level. References used in identification of each taxon are as follows: cephalopods (Gordon, 1964; Moore, 1964), brachiopods (Muir-Wood and Cooper, 1960; Moore, 1965; Henry and Gordon, 1992), bivalves (Moore and Teichert, 1969; Hoare, 1993), gastropods (Moore and Pitrat, 1960; Thein and Nitecki, 1974), bryozoans (McKinney, 1972), trilobites (Moore, 1959). A brief description of each genus is located in Appendix 2. Upon identification each specimen was placed in a collection tray labeled with the genus name, age of the sample, location and date of collection, and collector's name. All genera for each sampled unit were stored together in cabinets labeled with outcrop location and unit designation.

\subsection{Multivariate Techniques}

A data set containing all the sampled units and identified genera was compiled in Excel, and four multivariate analysis techniques were employed for interpretation. The original spreadsheet contained binary presence/ absence data for each genus per sampled unit. Taxonomic abundance counts were not performed because binary data will yield 
similar results as abundance data using various multivariate techniques if the underlying paleoecologic signal is strong (Kammer and Lake, 2001). Data for the Eads Mill returned robust patterns using multivariate analysis, which precluded having to make taxon counts.

The three initial multivariate techniques used in interpreting the data were cluster analysis, non-metric multi-dimensional scaling (MDS), and correspondence analysis. Cluster analysis produces a dendrogram that combines taxa/guilds, or samples, of highest similarity together. This forces the data into groupings based on their degree of similarity which helps illustrate which objects are most closely related ecologically. Cluster analysis produces groupings based on similarities between objects but it cannot demonstrate gradients in the data. The second technique is non-metric MDS, which places the resulting groups in a low-dimensional Euclidean space. The proximity between groups is related to their degree of similarity; groups close together are more similar than those farther apart (Lebold and Kammer, 2006). Unlike cluster analysis, MDS can show gradients within the data, so the distance between points is significant. The last technique is correspondence analysis, which plots both the Q-mode (sample) and R-mode (taxa) together; this spatially shows how closely related individual taxa are to specific samples. The software PAST (Hammer et al., 2007) was used to conduct all multivariate analyses. 


\section{Data}

\subsection{Outcrop Descriptions}

\subsubsection{Route 102 Virginia}

The first sampling location is along the west side of Rt. 102, just outside of Bluefield, VA (Location 1, Figure 1). Near the base of the section (Figure 6) are two ripple bedded sandstones (units 89, 90), previously identified as the Falls Mill Sandstone of Reger (1926; Figure 4). The lower sandstone incises the underlying shale and contains dewatering escape structures. The upper sandstone contains shale rip-up clasts, organic matter and small trace fossils. Bidirectional laminations in the lower sandstone indicate that it may represent a tidally influenced estuarine mouth bar. Two meters above the sandstones is an extremely fossiliferous limestone (unit 92) that contains many stenotropic taxa such as brachiopods, crinoids and fenestrate bryozoans. On top of the limestone is a thick (12 m) dark gray shale (unit 93). The shale is fissile throughout and holds scarce gastropods and poorly preserved bivalves. Above the shale two more argillaceous limestones (units 95, 96) that also illustrate open marine conditions by containing brachiopods, crinoids, and solitary rugose corals. Another 12 meter thick, dark gray shale (unit 97) overlies the second group of limestone units. It has thin $(1-10 \mathrm{~cm})$ bioclastic limestones made predominantly of Phestia bivalves interspersed within the shale that contains rare straight shelled cephalopods and trilobites. Centimeter thick beds of siderite are interspersed within the unit. Atop the shale is a gray sandstone (unit 98) that has flaser bedding with micaceous mud drapes and shows evidence of bidirectional paleocurrents. A sandstone (unit 99) containing Stigmaria plant fossils (Figure 5) 
commonly found in the Mississippian and Pennsylvanian (Gillespie et al., 1978), overlies the tidally influenced sandstone of unit 98 . The unit is capped by a rooted mudstone (unit 100) with a thin $(2 \mathrm{~cm})$ impure coal at the top.

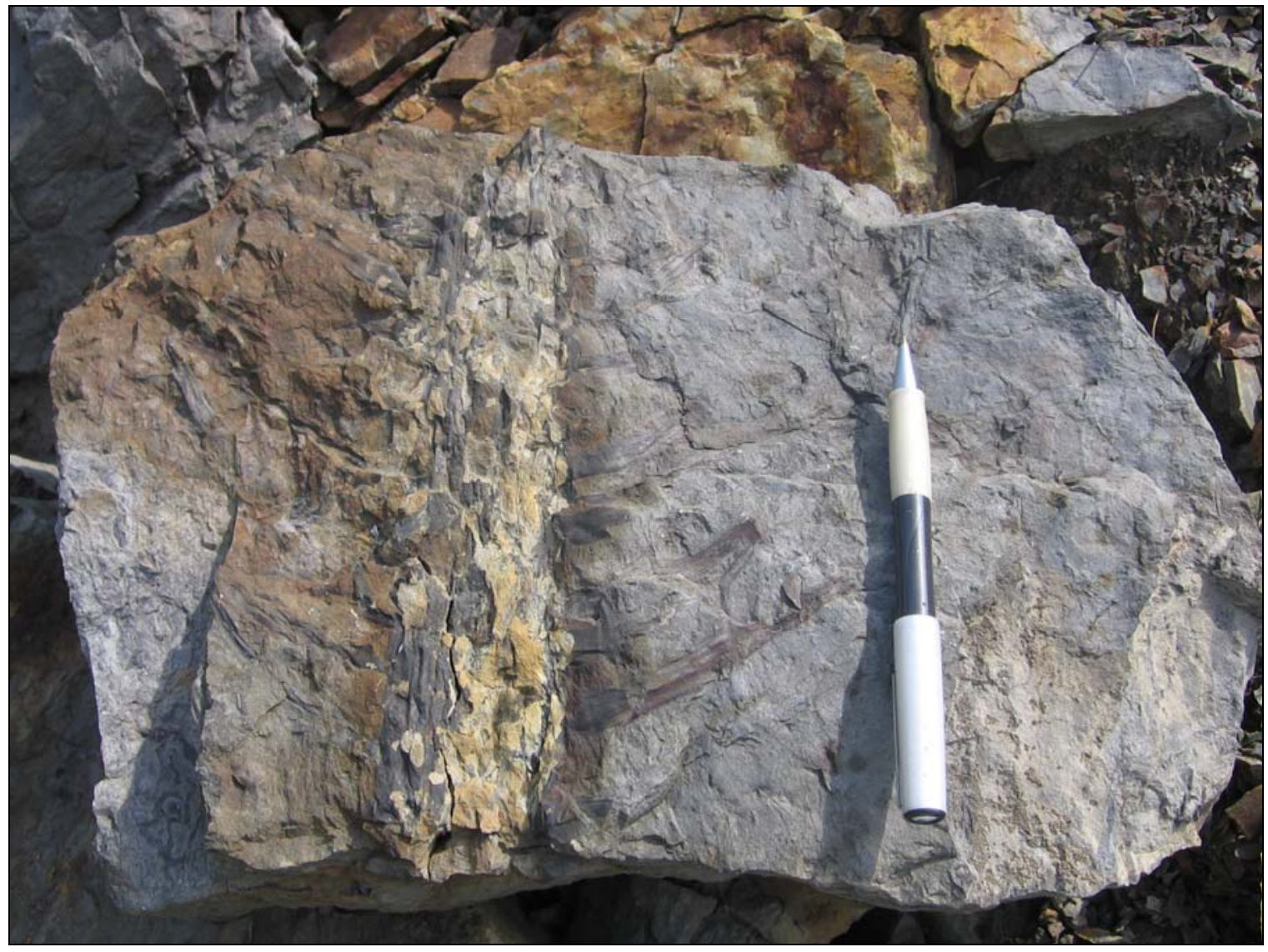

Figure 5. Stigmaria plant fossil from the Sample 99 sandstone along Rt. 102, VA. Such plant fossils found commonly in the Upper Mississippian and Pennsylvanian indicates a seasonally wet coastal environment (Gillespie et al., 1978). 
Rt. 102 Virginia

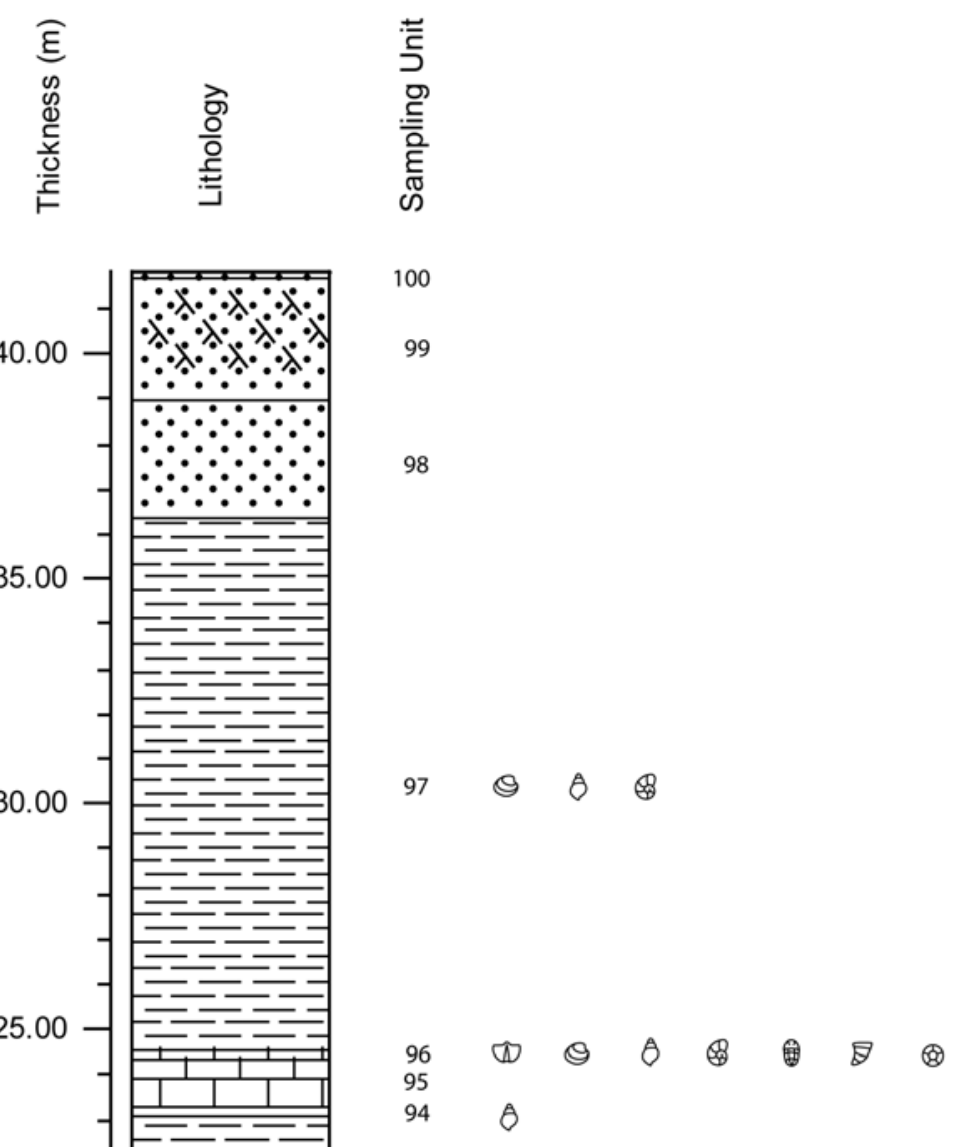

93

92 का 18 ( ) B

91

\begin{tabular}{|ll|}
\hline$\Delta$ & Brachiopod \\
$\theta$ & Bivalve \\
$\theta$ & Gastropod \\
$\theta$ & Cephalopod \\
$\theta$ & Trilobite \\
$\theta$ & Solitary Rugose Coral \\
$\lambda$ & Crinoid \\
\hline
\end{tabular}

$0.00-\therefore$

89

$88 \theta$ 
Figure 6. Stratigraphic column of the Rt. 102 Virginia outcrop showing lithology and taxa. Tidal sandstones (Samples 89, 90) at the base mark the transition from terrestrial to marine conditions. Water depth fluctuated during the deposition of the middle shales and limestones, and regressed back to terrestrial conditions marked by the uppermost sandstone and thin coal (Samples 99 and 100 respectively) at the top of the section. Sampling units for all five Eads Mill Member outcrops correspond with units identified in the descriptions provided by Jack Beuthin and Mitch Blake. Constituent fossil images for all five outcrop figures are courtesy of Jack Beuthin.

\subsubsection{Christian Fork Lake}

The second outcrop is on a hillside exposed next to Christian Fork Lake, just east of Princeton, WV near Rt. 460 (Location 2, Figure 1). This section is the shortest of the five and contains only three stratigraphic units (Figure 7). The base is a gray, unfossiliferous shale (unit 1), on which many large blocks from the overlying shale rest. Above the shale is a nearly meter thick bioclastic limestone (unit 2). Although biotic remains were noted, much material was highly abraded and locked within the crystalline limestone, both of which prevented identification. The topmost unit is a highly fossiliferous gray green shale (unit 3) containing a rich stenohaline fauna of brachiopods, bivalves, crinoids, fenestrate bryozoans and solitary rugose corals. The specimens weathered easily out of the shale, permitting a large sample size to be obtained. 


\section{Christian Fork Lake}
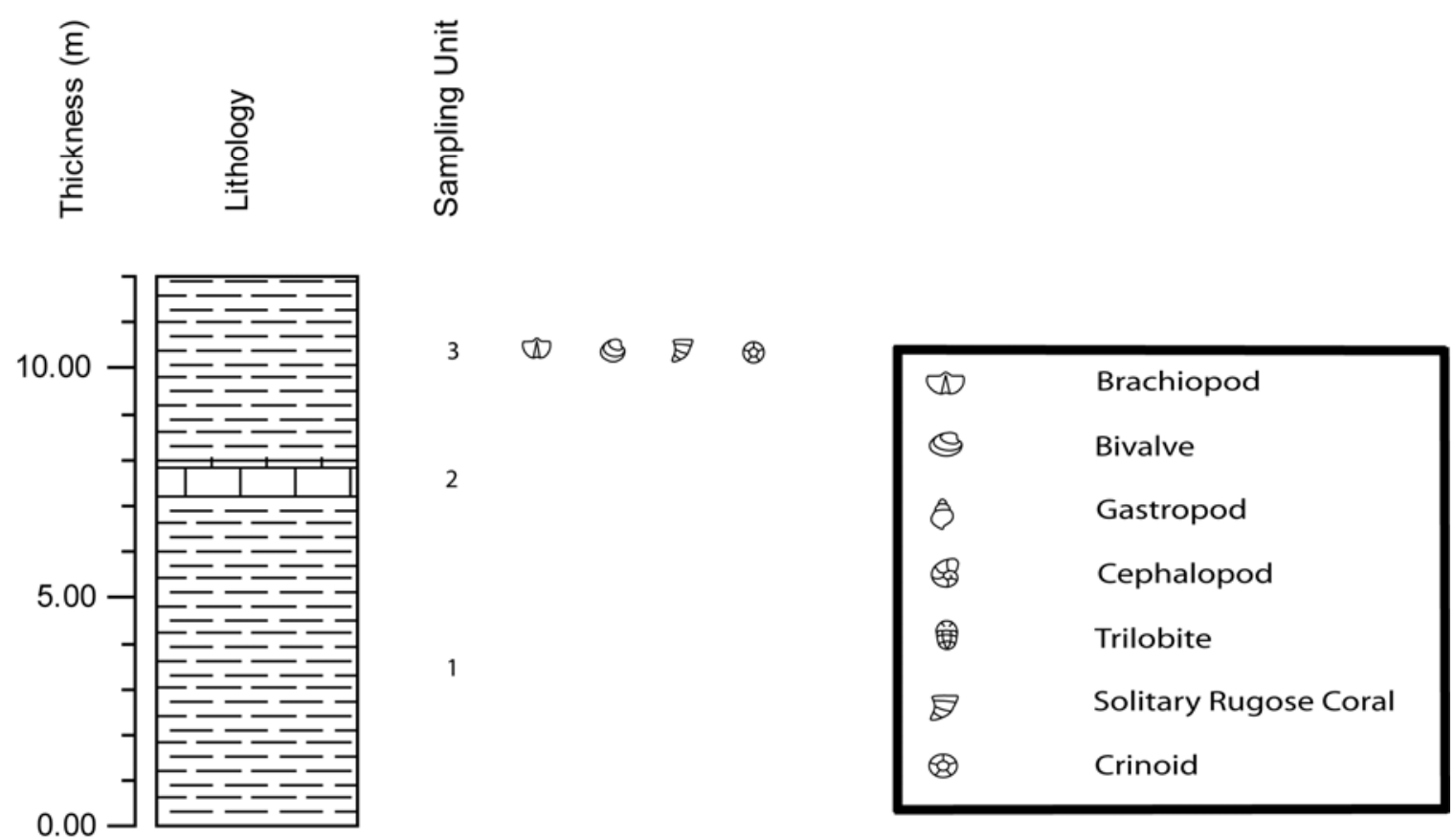

Figure 7. Stratigraphic column of the Christian Fork Lake outcrop showing lithology and taxa. The middle sample (2) is a highly abraded bioclastic limestone that did not permit collection or fossil identification. Sample 3 was highly fossiliferous and easy to disaggregate.

\subsubsection{Bluestone River Bridge along Eads Mill Road}

The next northward section is the type locality for the Eads Mill Member as described by Beuthin and Blake (2004) (Location 3, Figure 1). It is located along Mercer County Route 3 (Eads Mill Road) and extends from the road to underneath the I-77 bridge spanning the Bluestone River Gorge. The lowermost units are gray mudstones and shales (units 2 through 6), with fossiliferous units containing brachiopods, bivalves, gastropods and occasional cephalopods increasing in diversity up section (Figure 9). The shales and mudstones are overlain by a $1.5 \mathrm{~m}$ of limestones (units 7,8 ) containing 
brachiopods, solitary rugose corals, and fenestrate bryozoans. These limestones are devoid of bivalves and dominated by the tethered brachiopod Composita. Above the limestones is a thick (11.4 m), fissile, unfossiliferous olive gray shale (unit 9). The uppermost units (10 through 14) are interbedded fossiliferous shales and limestones. The shales weather extensively, permitting easy sampling. The limestones, which have easily recognized “toadstool” weathering, are bioclastic and crystalline (Figure 8). With the exception of a single bivalve taxon, these limestones and shales, like the limestones below, are also dominated by brachiopods and contain stenohaline taxa such as fenestrate bryozoans, crinoids, and solitary rugose corals (Figure 10). The Princeton Sandstone scours into the overlying units five meters above the top of the Eads Mill.

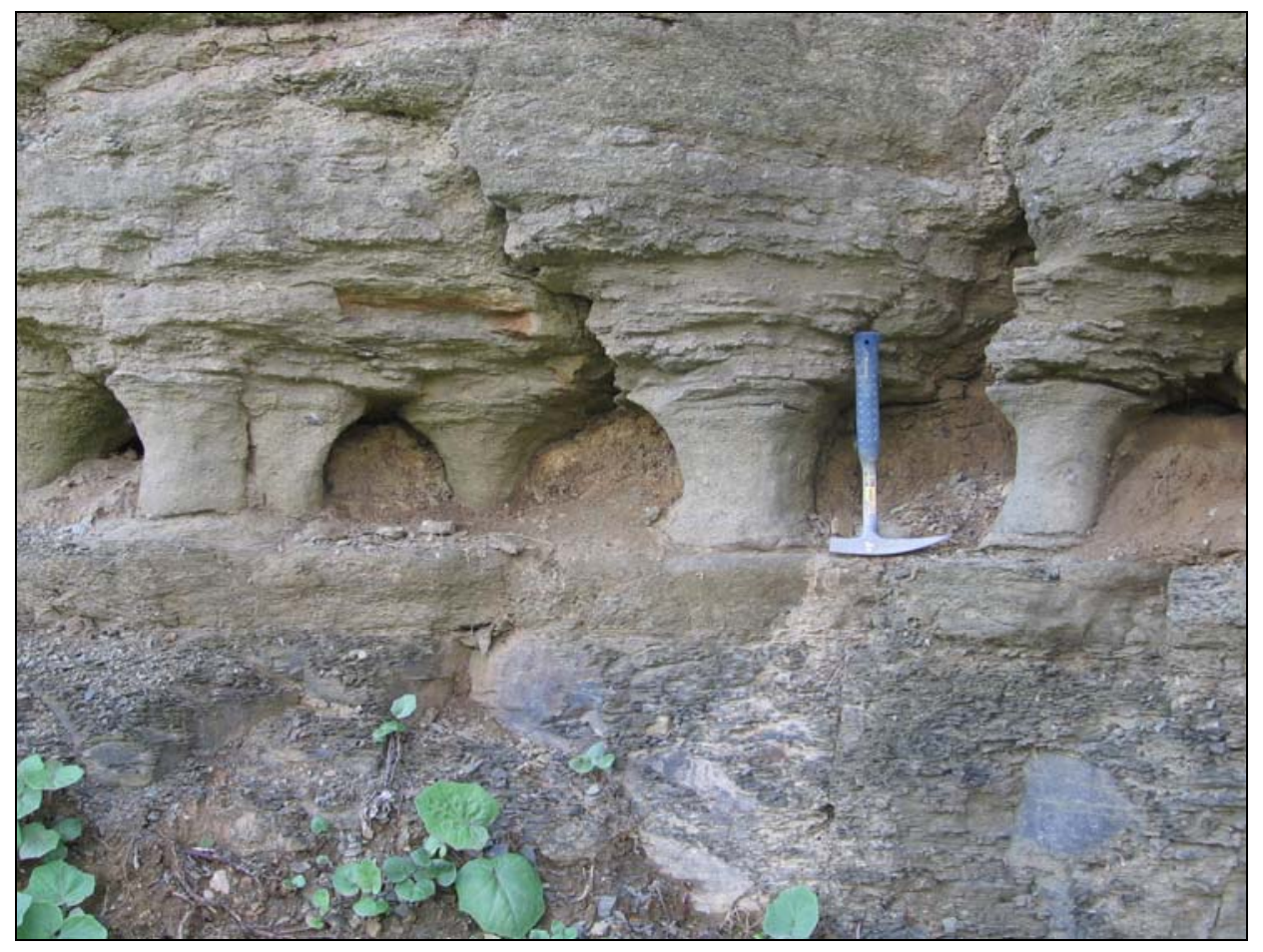

Figure 8. Characteristic "toadstool" weathering of the Sample 11 limestone underneath the Bluestone River Bridge. The highly fossiliferous Sample 12 shale crops out above the toadstool limestone. 


\section{Bluestone River Bridge}
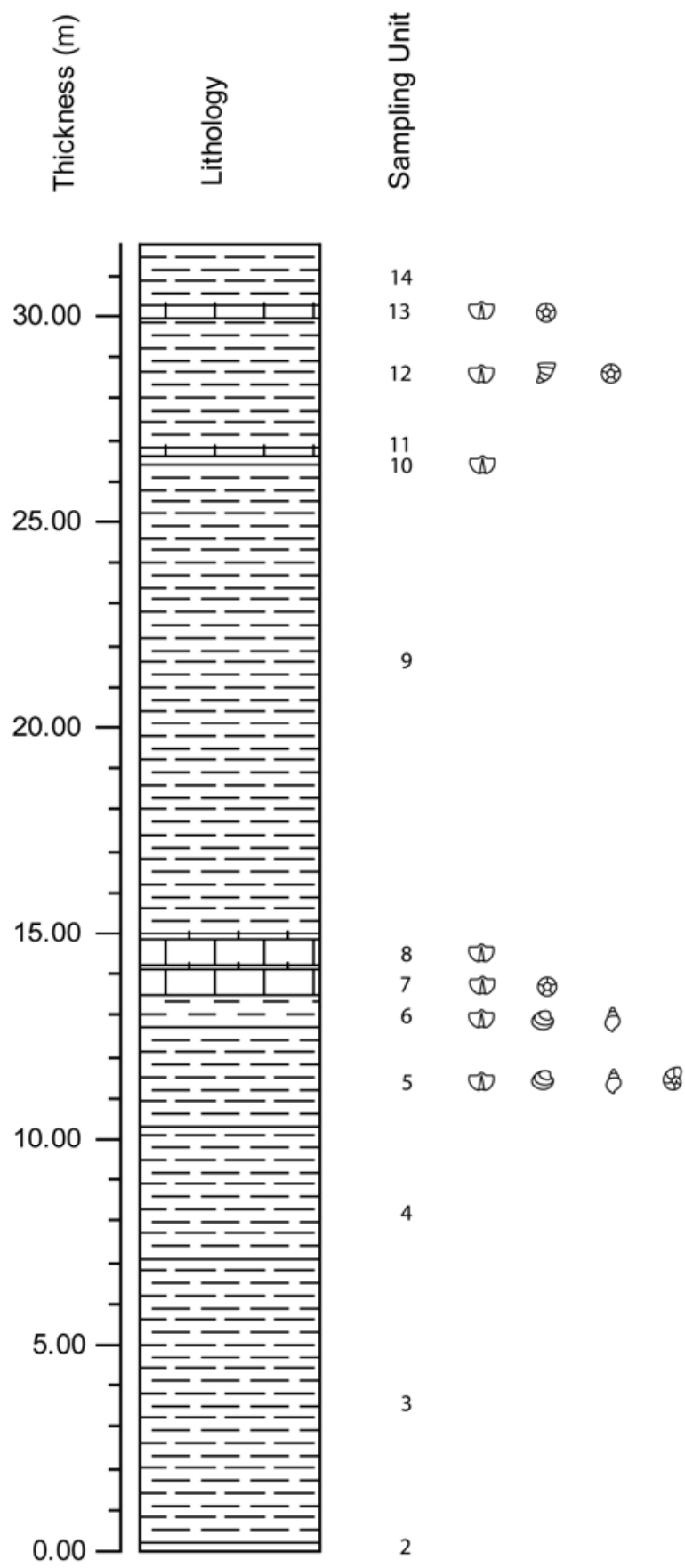

\begin{tabular}{|ll|}
\hline$A$ & Brachiopod \\
$\theta$ & Bivalve \\
$\theta$ & Gastropod \\
$\theta$ & Cephalopod \\
8 & Trilobite \\
$\theta$ & Solitary Rugose Coral \\
\hline
\end{tabular}

Figure 9. Stratigraphic column of the Bluestone River Bridge outcrop showing lithology and taxa. Limestones were crystalline and difficult to sample. Shale units were abundantly fossiliferous and easily disaggregated. 


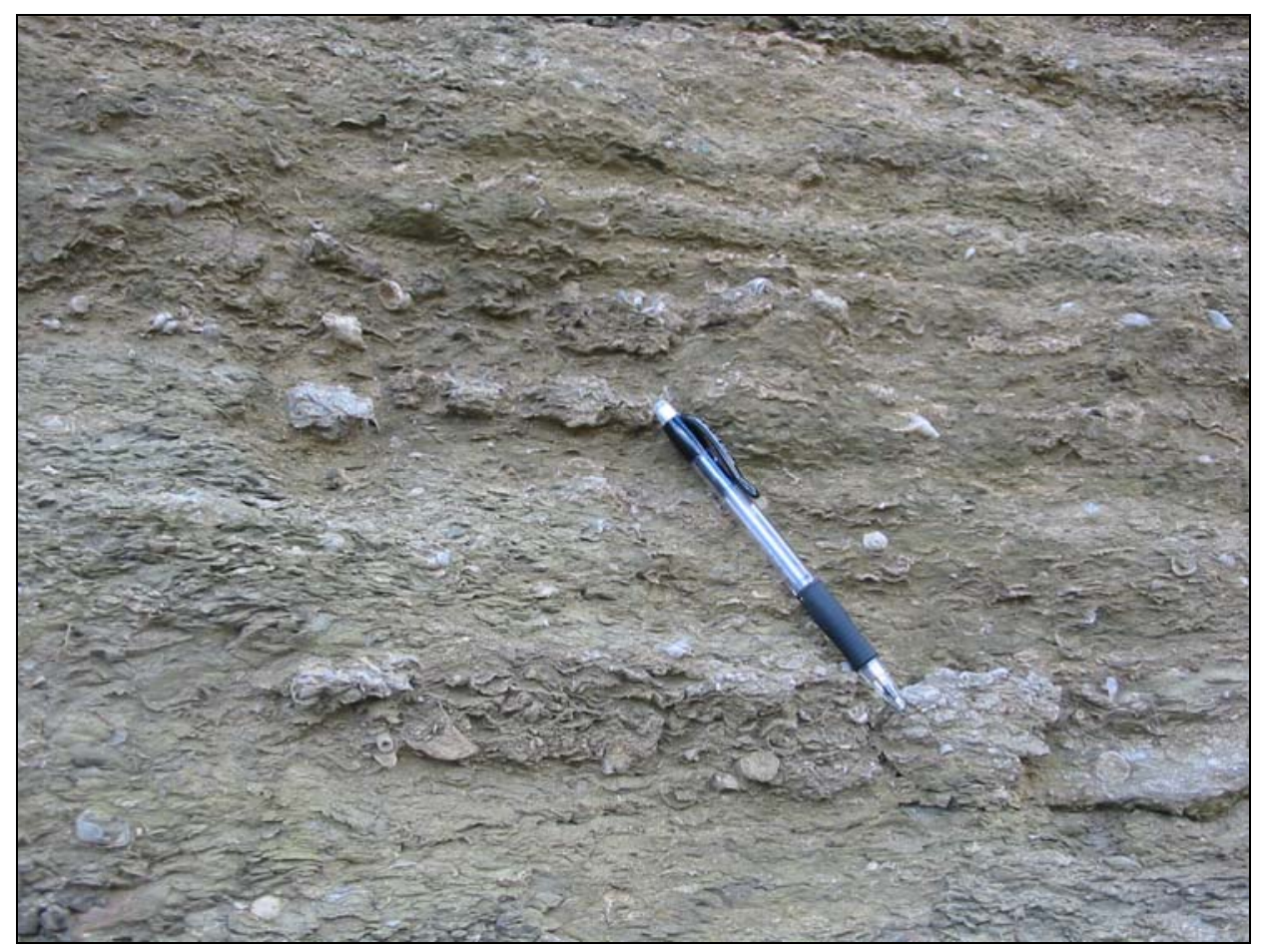

Figure 10. Close-up of the highly fossiliferous Sample 12 shale at the Bluestone River Bridge. The Sample 3 shale at Christian Fork Lake was identical to this, both having the same color and abundant taxonomic composition.

\subsubsection{Pipestem Creek}

The next outcrop farther north is located along WV Rt. 20 (Location 4, Figure 1) and is exposed on the west side of the road close to Pipestem Creek (Figure 12). The lowest fossiliferous unit is a crystalline bioclastic limestone (unit 63) that yielded only one genus of brachiopod, Anthracospirifer. Above the limestone are two gray shales (units 64, 66) with a concealed unit in between (Figure 11). The uppermost shale holds a few genera of bivalves near its base. The shale grades upwards into a calcareous mudstone (unit 67) then into an argillaceous limestone (unit 68). Both units have abundant brachiopod taxa, and also share occurrences of Bellerophon gastropods and fenestrate bryozoans. The mudstone contains additional stenohaline taxa such as crinoids 
and solitary rugose corals, whereas the limestone displays a resurgence of bivalves coexisting with the brachiopods. A shale containing brachiopods and fenestrate bryozoans (unit 71) is situated above three meters of unfossiliferous shale and siltstone (units 69, 70). The uppermost unit is an olive gray shale that includes thin lenses of sandstone (unit 72). Although no body fossils were noted, the sandstone shows feeding trace bioturbation along bedding planes. The Princeton Sandstone incises the uppermost unit.

\section{Pipestem Creek}
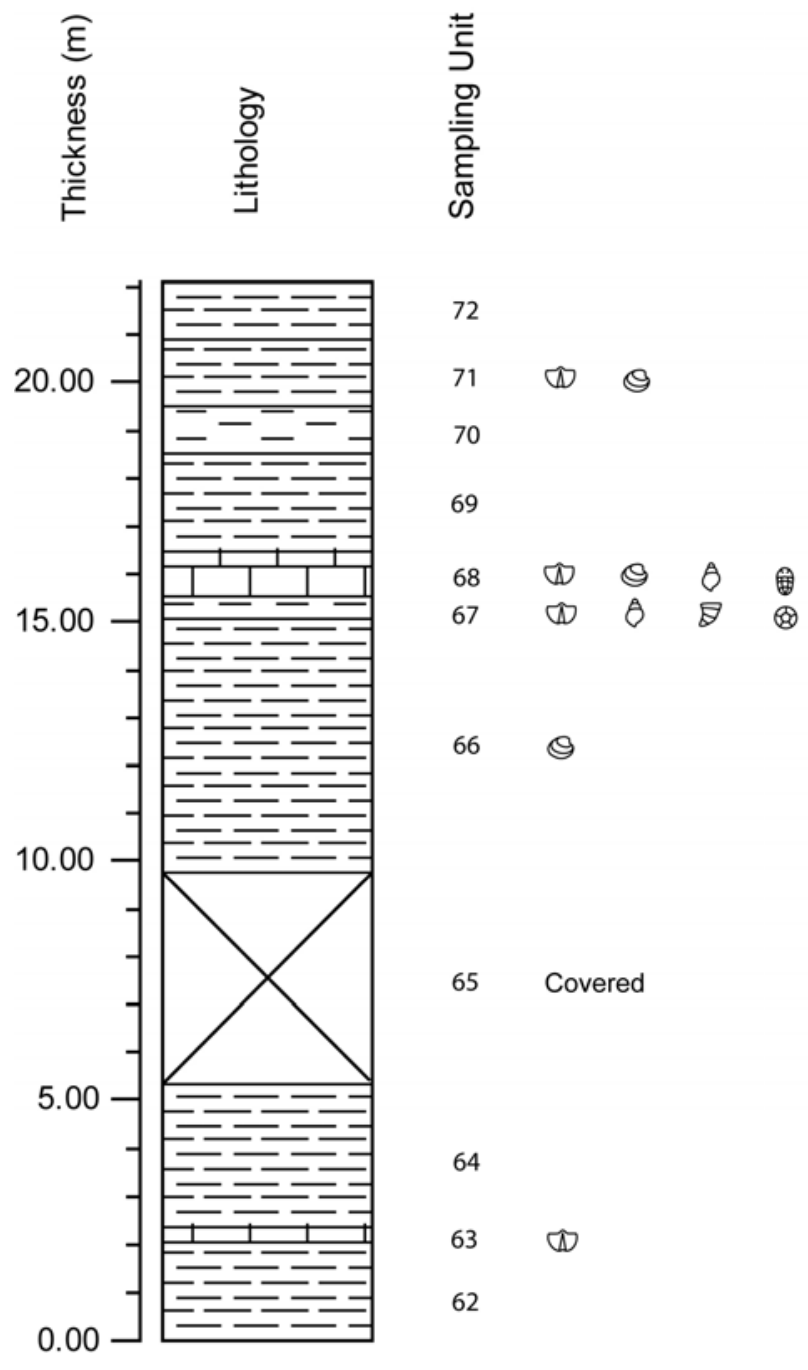

\begin{tabular}{|ll|}
\hline$A$ & Brachiopod \\
$\theta$ & Bivalve \\
$\theta$ & Gastropod \\
$\theta$ & Cephalopod \\
$\theta$ & Trilobite \\
$\theta$ & Solitary Rugose Coral \\
$\theta$ & Crinoid \\
\hline
\end{tabular}


Figure 11. Stratigraphic column of the Pipestem Creek outcrop showing lithology and taxa. Samples 67 and 68 contained the most diverse and most abundant fossil assemblage, and were the easiest units to sample. As shown at the top of Figure 12, the fluvial Princeton Sandstone truncates the top of Sample 72.

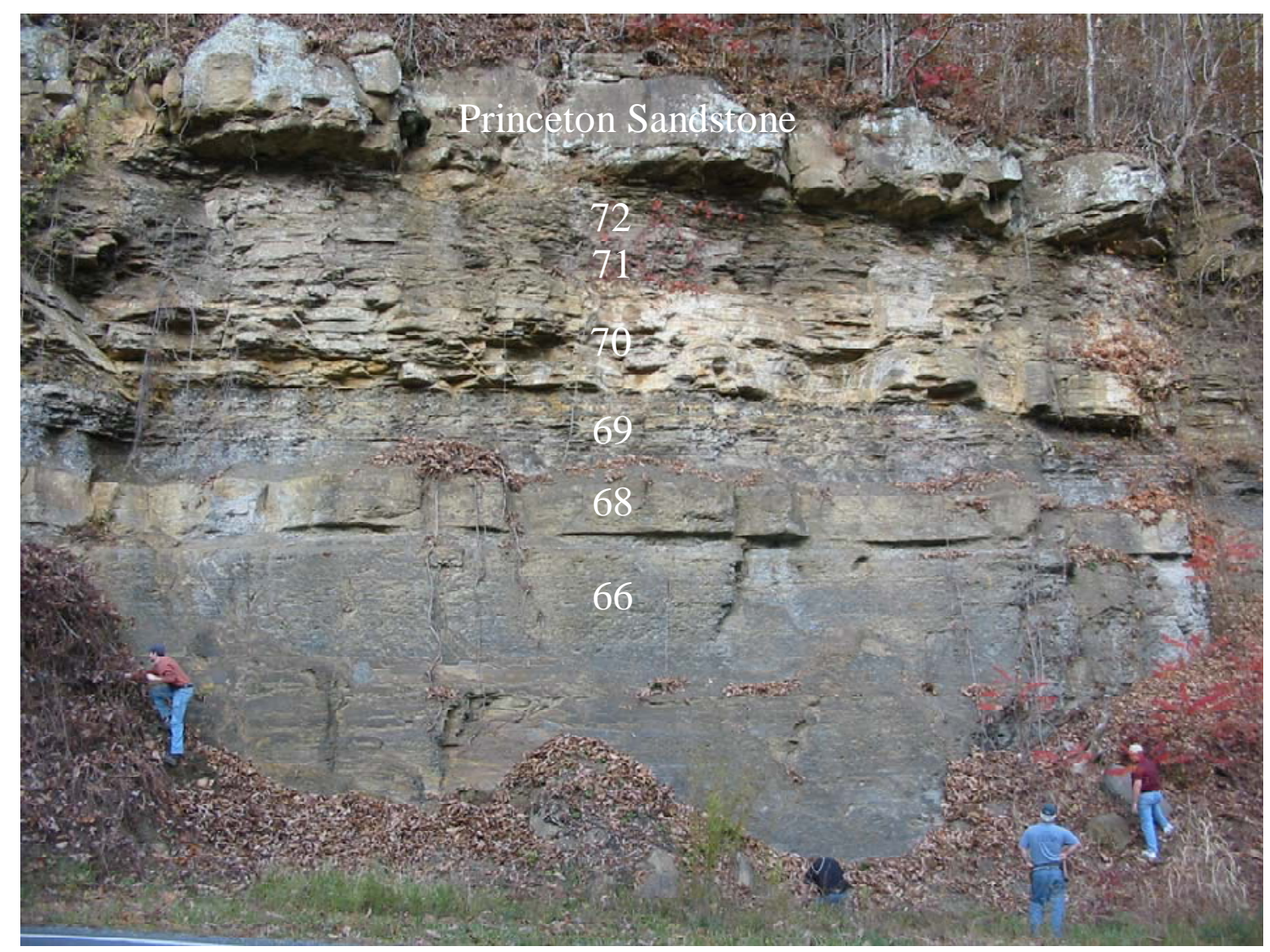

Figure 12. Eads Mill Member outcrop along the western side of WV Rt. 20 near Pipestem Creek. The Princeton Sandstone which forms the resistant ledge at the top of the outcrop incises unconformably into the top of the Eads Mill Member (Sample 72 of Figure 11). Sample numbers of major lithologic units corresponding to those in Figure 11 are labeled on the photograph.

\subsubsection{Interstate 64}

The northernmost outcrop is exposed along the north side of I-64, about 2.2 miles east of Exit 143 near Green Sulfur Springs, WV (Location 5, Figure 1). The Eads Mill begins with a transition from a red rooted mudstone into a strongly calcareous gray shale (unit 56) that has thin, dark gray laminations containing Modiolus and Septimyalina 
bivalves (Figure 13). A mudstone (unit 57), impure limestone (unit 58), and shale (unit 59) overlie the basal unit. The impure limestone (unit 58) correlates to the lower limestones found in the other three complete Eads Mill Member sections (Figure 14). No identifiable body fossils were noted but the shale contained thin, bivalve shell hash layers that were heavily abraded. Above the shale, a ripple cross-laminated sandstone (unit 60) grades upward into a half-meter thick immature paleosol with poorly developed slickensides (unit 61). Above the paleosol are two medium gray shales (units 62, 63), both of which have centimeter thick bands of siderite and contain euryhaline taxonomic assemblages. The lower shale represents a restricted fauna with Septimyalina and the only occurrence of the brachiopod Lingula, which can regulate its body’s ionic concentration and thus can survive in a wide range of ecologic conditions (Kammer and Lake, 2001). The upper shale contains an abundance of bivalves, gastropods, and occasional straight shelled cephalopods, all of which are most easily retrieved from above the runaway truck ramp as they weather out free from the top of the unit. Atop the shales is a bioclastic limestone (unit 64), which contains the only occurrence of crinoids and fenestrate bryozoans at this outcrop. In the limestone all bivalves from the underlying shale have been displaced by brachiopods, which also occurred in the lower limestone units $(7,8)$ from the Bluestone River Bridge outcrop (Figure 9). On top of the limestone is a thick (11.3 m), medium gray shale (unit 65) that also contains numerous siderite bands like those previously described. Above it is a small $(.2 \mathrm{~m})$ bioclastic limestone (unit 66) that holds numerous straight shelled cephalopods. The uppermost units begin with a shale (unit 67) that grades into a mudstone (unit 68) and finally a thin (0.1 m) limestone (unit 69), all of which are unfossiliferous. 


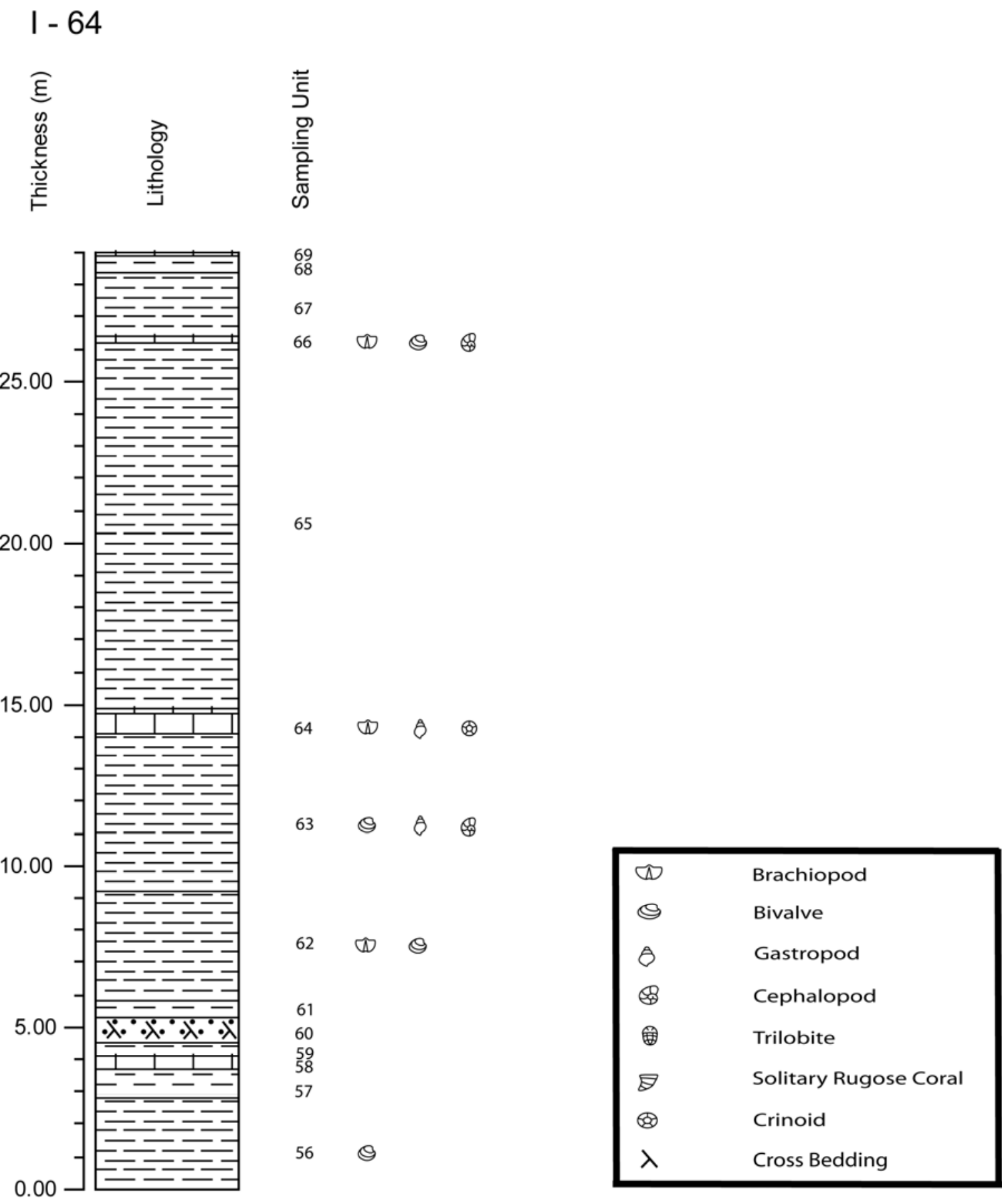

Figure 13. Stratigraphic column of the I-64 outcrop showing lithology and taxa. The most abundantly fossiliferous samples $(63,64)$ were located above the runaway truck ramp. 


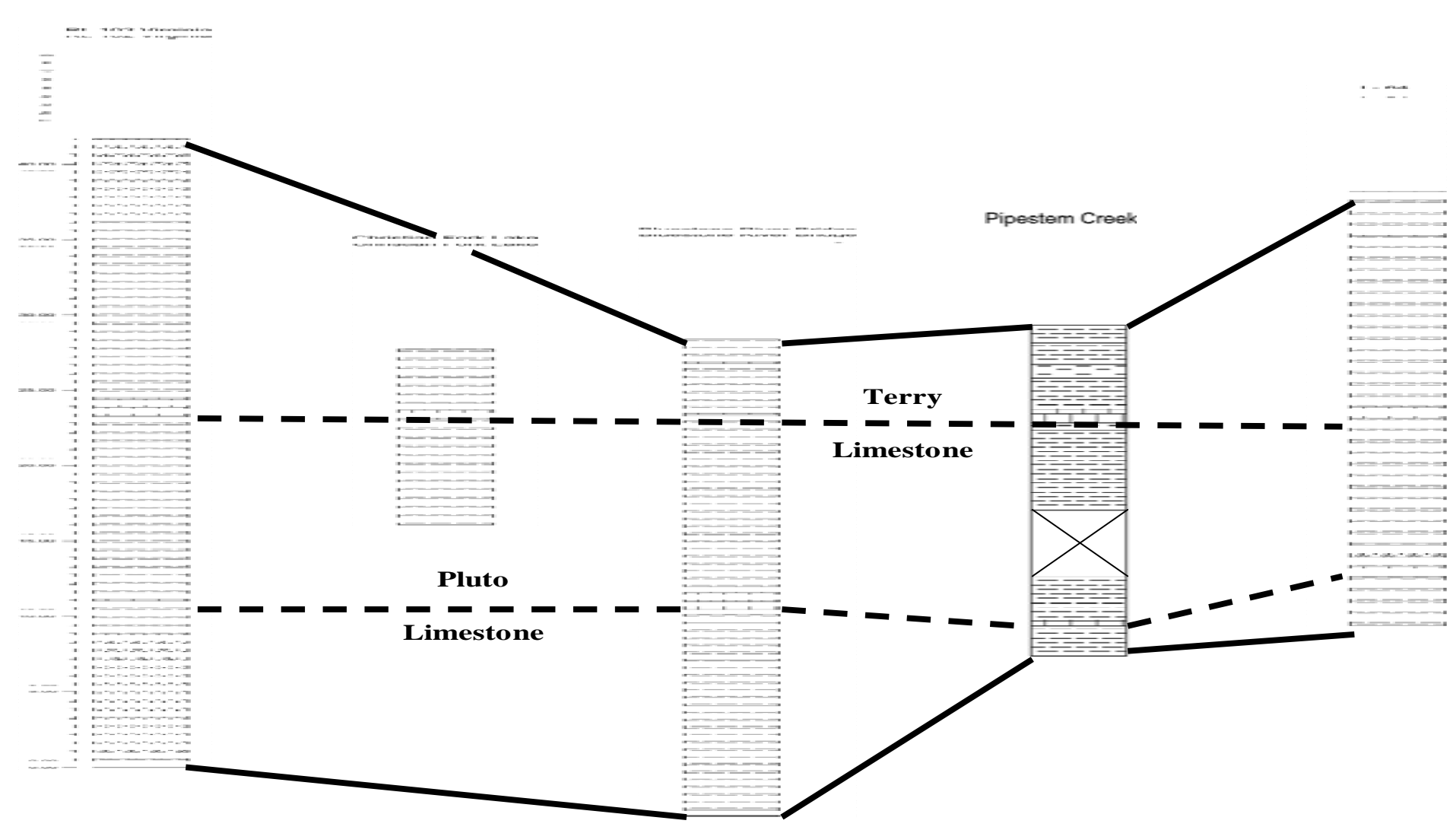

Figure 14. Correlation diagram through the five described Eads Mill Member sections (Figure 1). The solid lines correlate the identified top and bottom of the Eads Mill Member. At the Bluestone River Bridge and the Pipestem Creek locality the Princeton Sandstone lies unconformably atop the Eads Mill Member. The dashed lines correlate the Pluto and Terry Limestones of Reger's 1926 work (Figure 4), which represent the two maximum transgressive surfaces deposited in the Eads Mill Member. The Christian Fork Lake middle limestone (Figure 7, sample 2) and upper shale (sample 3) share the same lithology and constituent taxa with the upper Bluestone River Bridge samples 11 and 12 respectively (Figure 8). Stratigraphic columns are place in position based on occurrence from south to north with no horizontal scale implied 


\subsection{Invertebrate Fossils}

The most abundant fossil taxa in the Eads Mill Member were brachiopods (Figure 18), which contained 13 different genera (Table 1). With the exception of Lingula, are all stenohaline (Kammer and Lake, 2001; Lebold and Kammer, 2006). Brachiopods were identified in 17 of the 23 sampled intervals. Bivalves (Figure 15) had the second highest generic abundance in the Eads Mill Member (10), and were found in 14 of the 23 samples. In nine samples, both brachiopods and bivalves were found together, indicating that bivalves were suited to living in stenotropic conditions.

The remaining 13 genera show strong associations to either the brachiopod or bivalve taxa. Brachiopods were found in association with the eight samples that contained characteristic stenotropic taxa (bryozoans, crinoids, rugose corals (Figure 17)). Conversely, six of the nine samples containing gastropods, and all six samples with the cephalopod Reticycloceras (Figure 16) were found in association with bivalves. The single occurrence of ostracods was also with bivalves, whereas the only other genera found with the single sample of Paraconularia were brachiopods. Trilobites were identified in two of the nine samples that contained both brachiopods and bivalves. Thus brachiopods and typical stenotropic taxa are closely associated with each other, while bivalves are associated with other eurytropic taxa, though bivalves were could also survive in stenotropic conditions. 
Table 1. Complete list of all 36 Eads Mill Member genera and 10 taxonomic types.

\begin{tabular}{|c|c|}
\hline Таха Tyре & Constituent Genera \\
\hline Brachiopods & $\begin{array}{l}\text { Anthracospirifer, Cleiothyridina, Composita, Diaphragmus, } \\
\text { Eumetria, Flexaria, Fluctuaria, Inflatia, Lingula, Orthotetes, Ovatia, } \\
\text { Punctospirifer, Torynifer }\end{array}$ \\
\hline Bivalves & $\begin{array}{l}\text { Aviculopecten, Cardiomorpha, Edmondia, Ectogrammysia, Modiolus, } \\
\text { Nuculopsis, Paleyoldia, Phestia, Schizodus, Septimyalina, }\end{array}$ \\
\hline Gastropods & Bellerophon, Euphemites, Ianthinopsis, Knightites, Naticopsis \\
\hline Cephalopods & Reticycloceras \\
\hline Trilobites & Paladin \\
\hline Corals & Solitary rugose corals \\
\hline Bryozoans & Archimedes, Encrusting \\
\hline \multicolumn{2}{|l|}{ Crinoid } \\
\hline \multicolumn{2}{|l|}{ Ostracods } \\
\hline Paraconularids & Paraconularia \\
\hline
\end{tabular}




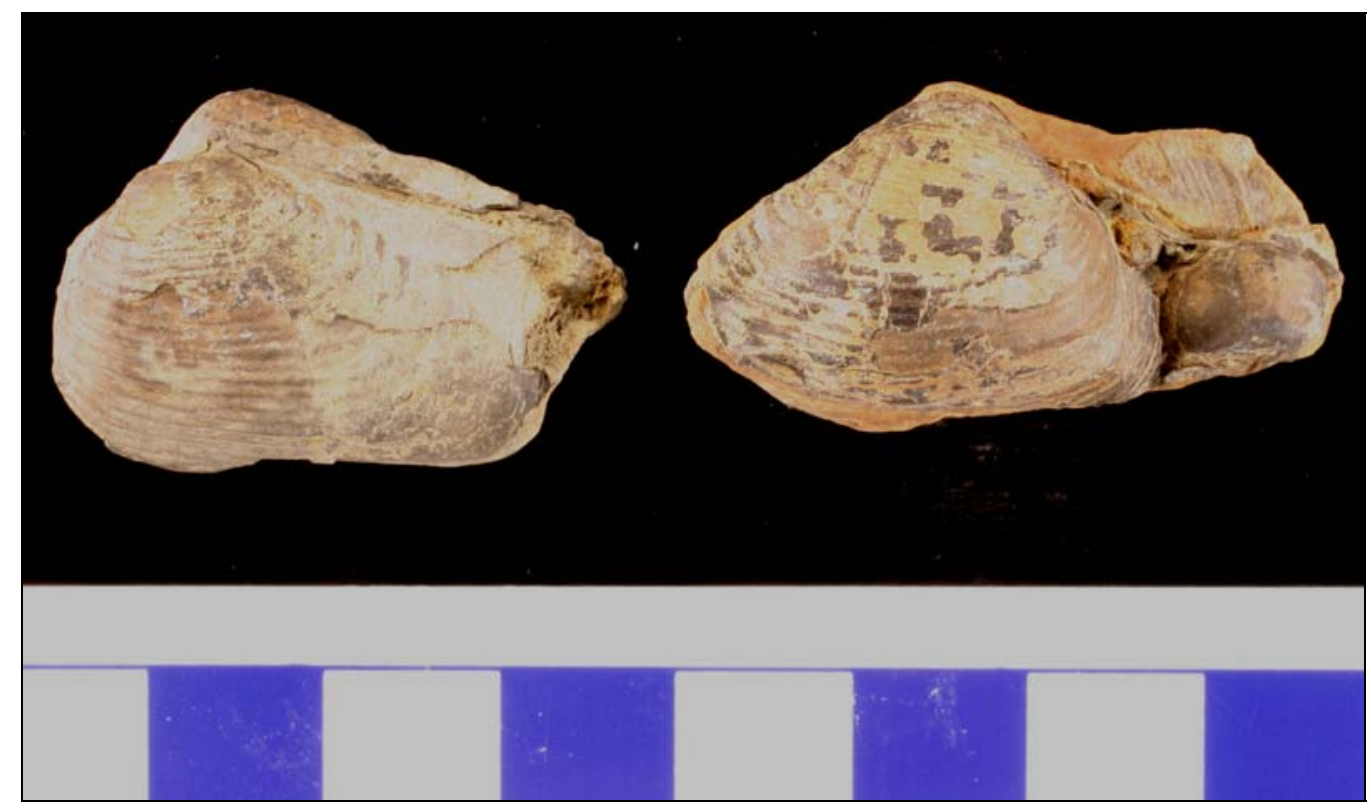

Figure 15. The bivalve Ectogrammysia was identified by the very coarse concentric growth lines extending from its hinge. It was found within at least one sampled interval at each outcrop. Scale bar is in centimeters.

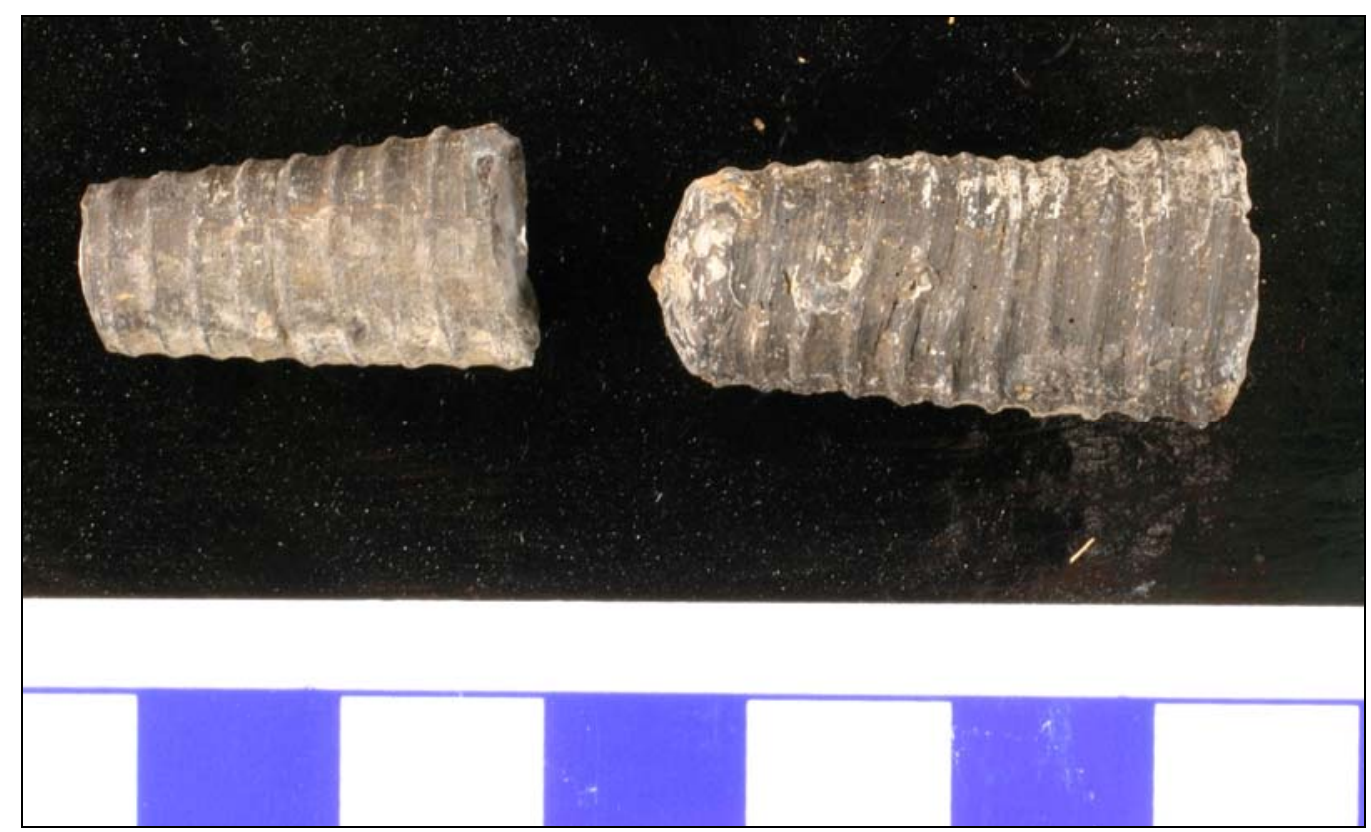

Figure 16. The straight shelled nautiloid Reticycloceras has relatively parallel septa that are closely spaced together. It was commonly identified with the other euryhaline taxa. Scale bar is in centimeters. 


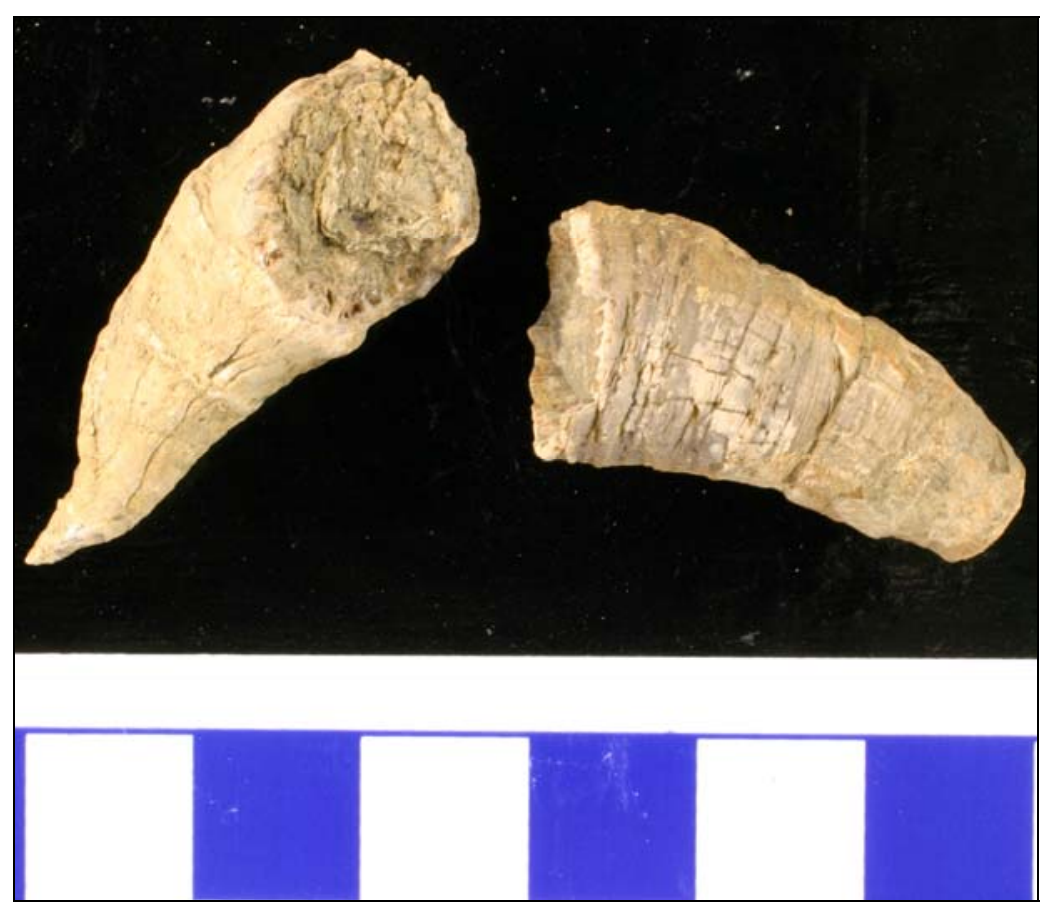

Figure 17. Solitary rugose corals were found in association with crinoids, bryozoans, and many genera of brachiopods. Corals, like bryozoans and crinoids, have a very narrow tolerance to salinity variability, and when identified within a sample are an indicator of open marine, stenohaline conditions in the depositional environment (Kammer and Lake, 2001). Scale bar is in centimeters.

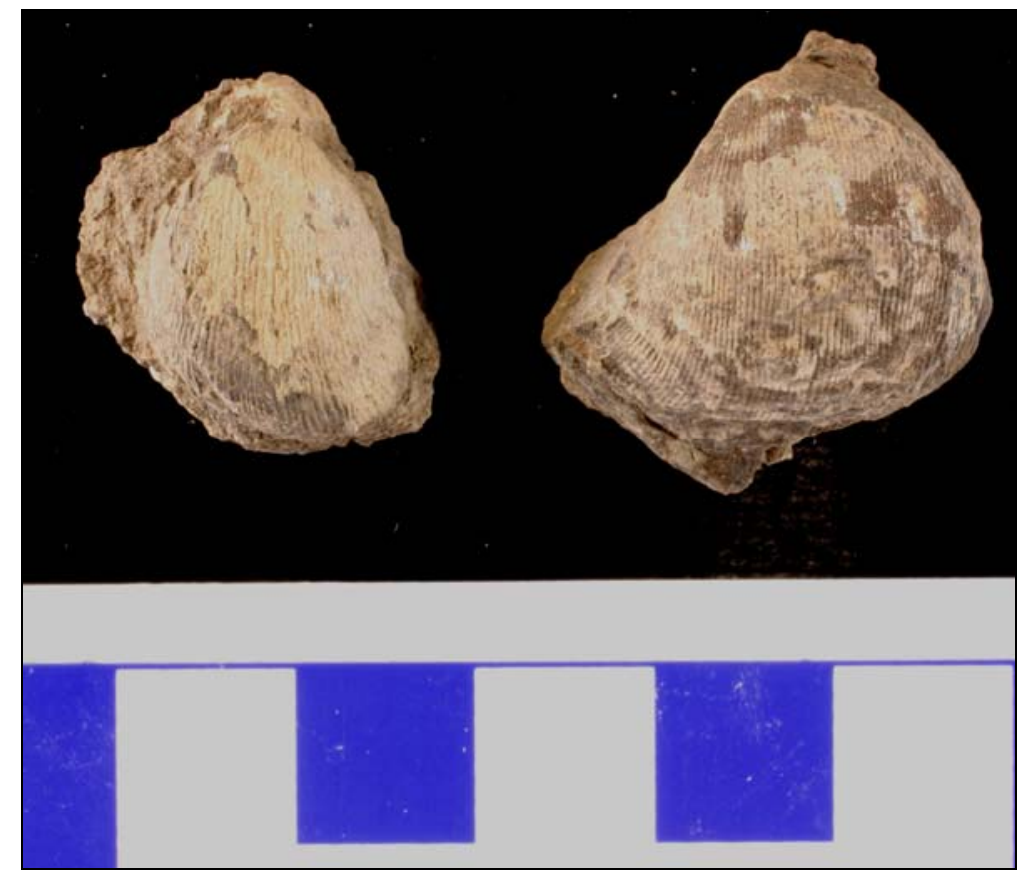

Figure 18. One of the most common taxa in all samples, the productid brachiopod Ovatia has very fine ribs closely spaced together on its pedicle valve. 


\subsection{Multivariate Matrices and Analyses}

All generic and sample data were placed into an Excel spreadsheet after laboratory identification was completed. The original binary data set comprised 23 samples and 36 identified genera (Table 2). Multivariate analysis was conducted on the original data to see what patterns might be present. While some subtle trends were noticed, it was determined that there was too much noise in the data, as indicated by the stress values in MDS. Stress values measure the goodness of fit of the data to a linear curve. Stress values range from 0 to 1 , with low values indicating a good fit while high values (>0.40) indicate a poor fit (Rohlf, 1998; Lebold and Kammer, 2006). With Rmode data approaching 0.40 stress values, the data was simplified to make any patterns more apparent. To accomplish this, taxa with only one occurrence were removed from the data, as were the samples containing only one genus. This minor filtering of low density data resulted in stress values for both $\mathrm{Q}$ and $\mathrm{R}$-mode values in the $0.15-0.20$ range, and made previously noted patterns in the data more obvious.

To further simplify the diverse assemblage of taxa, seven guilds were constructed in order to reduce the number of variables in the data set. The constituents of each guild all shared similar morphology, food source preference and characteristic life habits (Bambach, 1983). Since all the members of the guild shared these commonalities, each guild acted as a single proxy for the multiple genera it encompassed (Kammer and Lake, 2001). Each taxon was evaluated on the above mentioned characteristics, and was placed into its respective category (Table 3) using published guilds by Kammer and Lake (2001) 
and Lebold and Kammer (2006). The resulting seven guilds were: osmo-conformers which included crinoids, bryozoans and corals, tethered brachiopods, productid brachiopods, infaunal bivalves, epifaunal bivalves, gastropods, and cephalopods. During construction of the guilds, taxa with two or fewer occurrences and samples containing two or fewer genera were removed from the data (Table 4). Counts of constituent guild taxa occurring at each sampling interval were then performed and tabulated in Table 5. Data processing, reduction, and the formation of guilds reduced the R-mode data from 36 original variables to seven, and the Q-mode data from 23 samples to 18, thereby significantly reducing the noise and stress in the data, and amplifying the underlying paleoecological signal.

Binary data from the seven guilds was loaded into the PAST software, and three multivariate analyses were initially conducted. Both Q-mode (sample) and R-mode (guild) data was used in order to identify common trends within the data set. Cluster analysis was performed on the Q-mode (Figure 19) and R-mode (Figure 20) data, and groupings were combined into marginal and open marine categories. Marginal marine conditions vary in salinity from 5-30\%, whereas open marine conditions are stabilized near 35\%. Likewise, Q-mode (Figure 21) and R-mode (Figure 22) non-metric MDS plots were also generated. Both samples and guilds were separated into marginal and open marine groupings. Correspondence analysis combining both Q and R-mode data on the same chart (Figure 23), showed a distinct trend of increasing salinity stability moving from marginal to open marine groupings of associated samples and guilds. 
Table 2. Original binary data set containing all identified fossil genera and sampling intervals. Samples are arranged by outcrop locality, and numbers correspond to sampled unit on their associated stratigraphic column. A 1 indicates that the genus was identified in the sample, while a 0 indicates that it was absent.

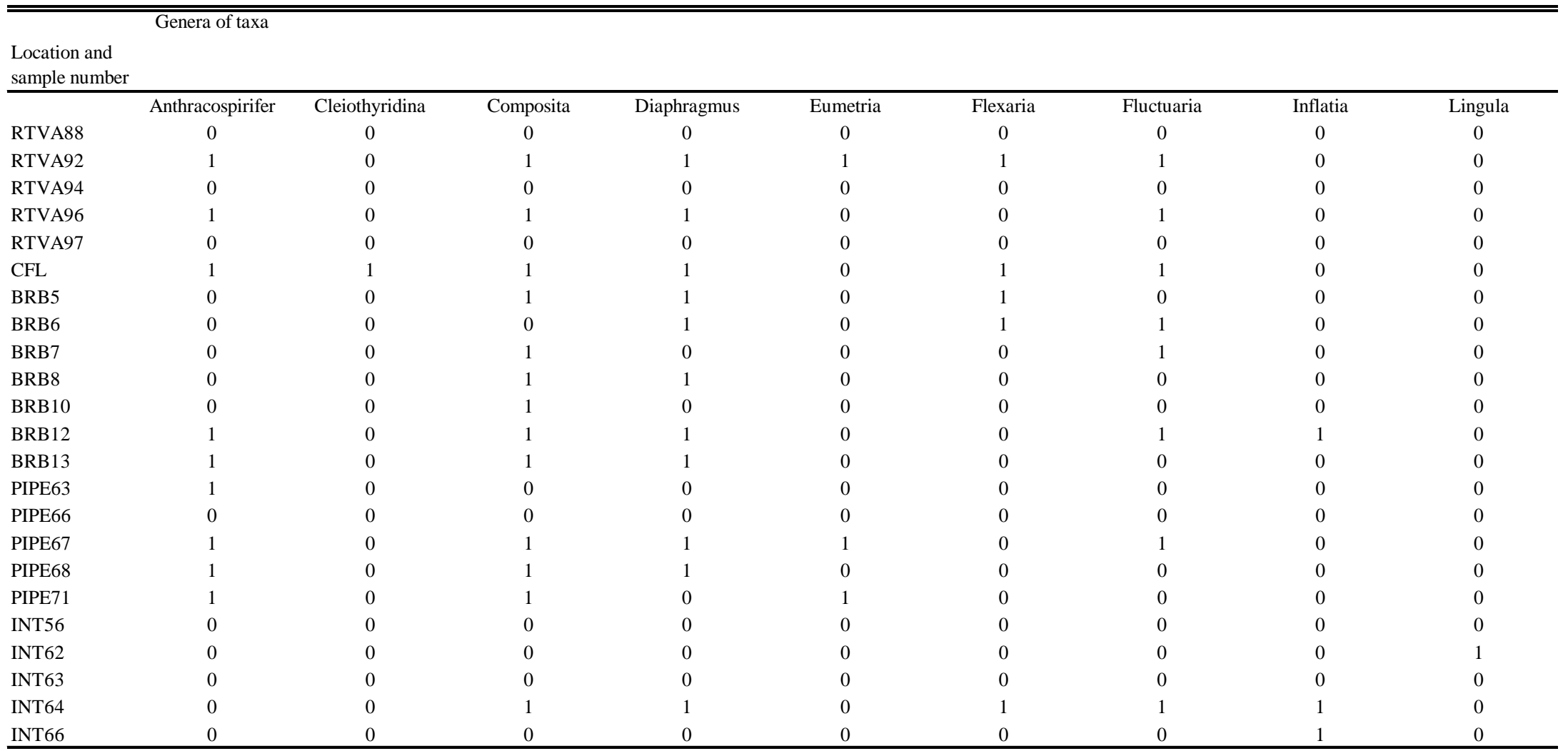


Table 2. Continued

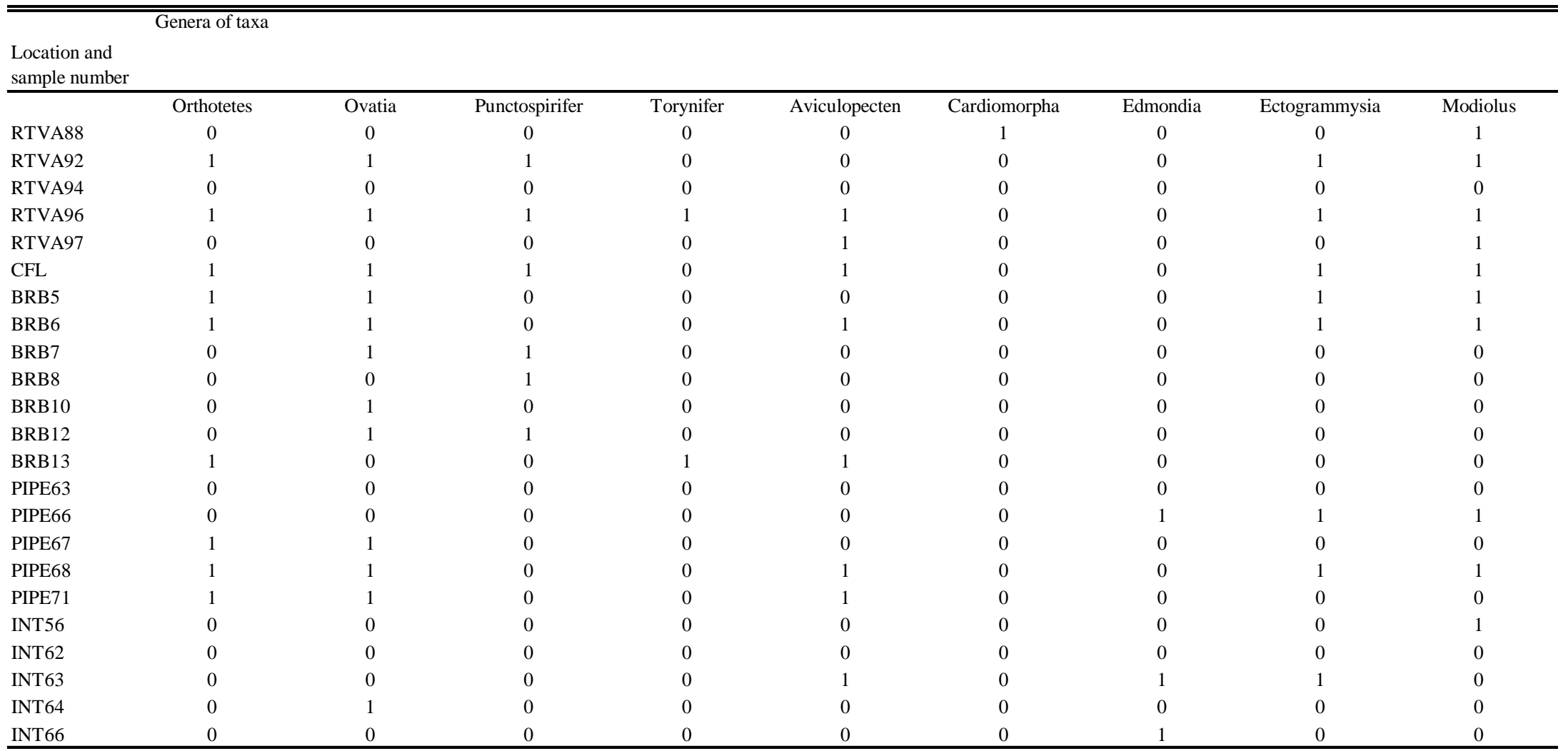


Table 2. Continued

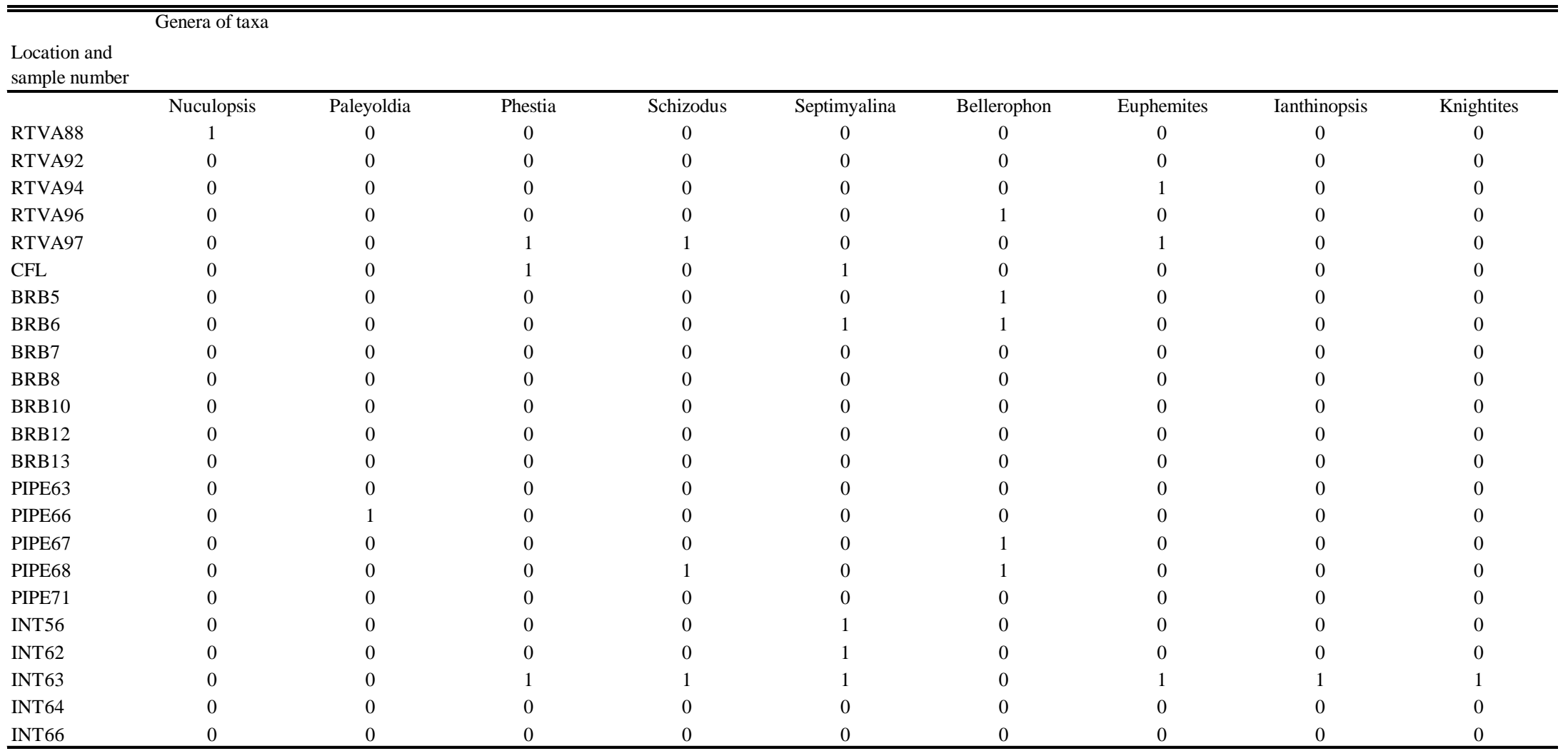


Table 2. Continued

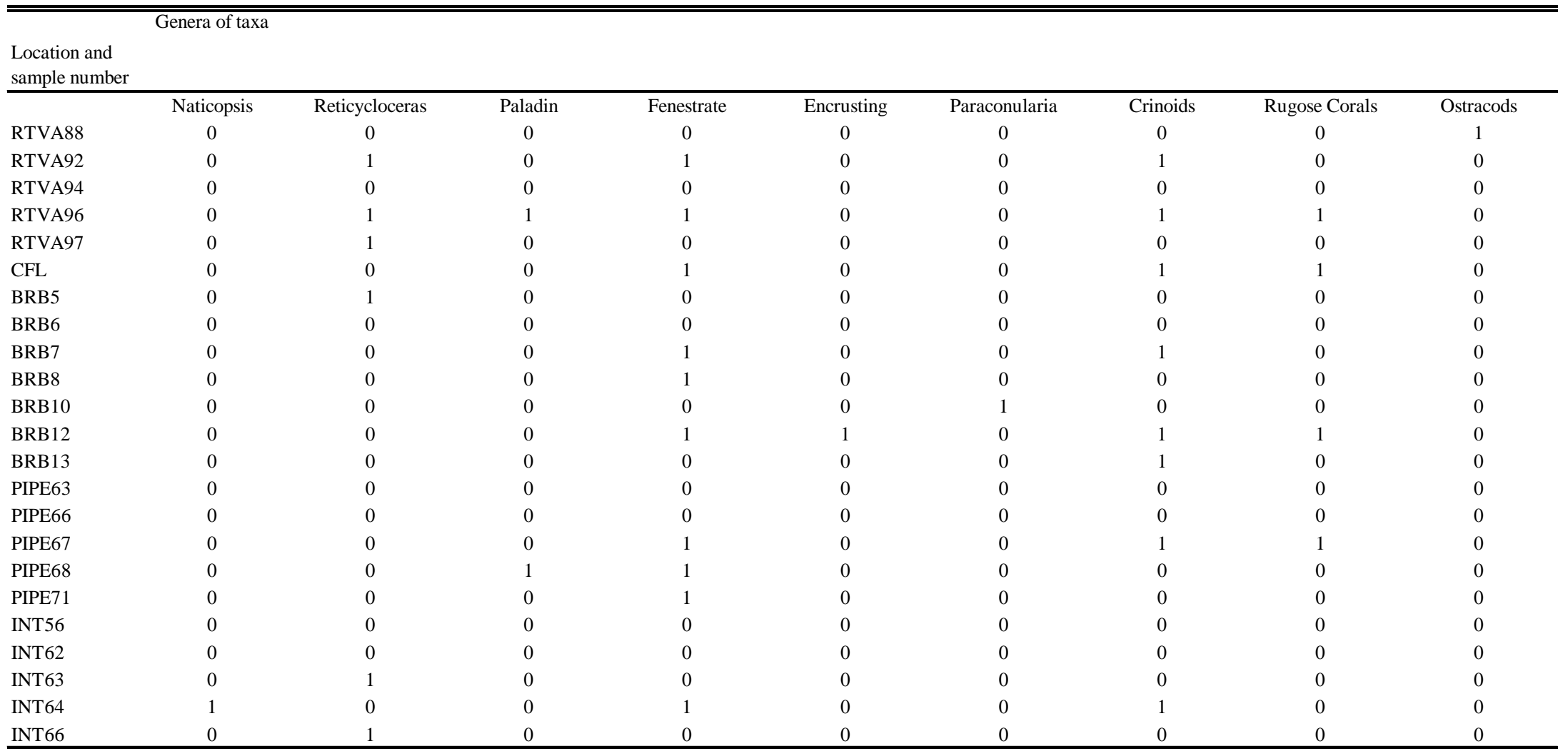


Table 3. Constituent taxa of 7 constructed guilds. Taxa with two or fewer total occurrences were removed from the data to reduce the noise and enhance the underlying paleoecologic signal.

\begin{tabular}{|c|c|c|c|c|}
\hline Guild & $\begin{array}{l}\text { Constituent } \\
\text { Genera }\end{array}$ & & & \\
\hline $\begin{array}{l}\text { Tethered } \\
\text { Brachiopods }\end{array}$ & Anthracospirifer & Fluctuaria & Composita & Eumetria \\
\hline (T.BRACH) & Orthotetes & Punctospirifer & Flexaria & \\
\hline $\begin{array}{l}\text { Productid } \\
\text { Brachiopods }\end{array}$ & Diaphragmus & Inflatia & Ovatia & \\
\hline (PROD.BRACH) & & & & \\
\hline $\begin{array}{l}\text { Infaunal Bivalves } \\
\text { (IN.BIV) }\end{array}$ & Ectogrammysia & Edmondia & Schizodus & Phestia \\
\hline $\begin{array}{l}\text { Epifaunal } \\
\text { Bivalves } \\
\text { (EPI.BIV) }\end{array}$ & Aviculopecten & Modiolus & Septimyalina & \\
\hline $\begin{array}{l}\text { Gastropods } \\
\text { (GASTRO) }\end{array}$ & Bellerophon & Euphemites & & \\
\hline $\begin{array}{l}\text { Cephalopods } \\
\text { (CEPHALO) }\end{array}$ & Reticycloceras & & & \\
\hline $\begin{array}{l}\text { Osmo-conformers } \\
\text { (OSMO) }\end{array}$ & Rugose Corals & Crinoids & Archimedes & \\
\hline
\end{tabular}


Table 4. Taxa with two or fewer occurrences that were removed from the data set during the construction of guilds.

\begin{tabular}{cccc}
\hline \hline Guild & Constituent genera & & \\
Tethered & & & \\
Brachiopods & Cleiothyridina & Torynifer & Lingula \\
Infaunal Bivalves & Paleyoldia & Nuculopsis & Cardiomorpha \\
Gastropods & Ianthinopsis & Knightites & Naticopsis \\
Trilobites & Paladin & & \\
Paraconularids & Paraconularia & & \\
Osmo-conformers & Encrusting bryozoa & \\
Ostracods & Ostracods & \\
\hline
\end{tabular}


Table 5. Outcrop samples and seven guilds constructed from binary count data. After presence/ absence data were compiled for all genera, counts of constituent members at each guild for every sampling interval were compiled. The sample lithology is also noted, and corresponding lithologic abbreviations are as follows: SH - Shale, LS - Limestone, MS - Mudstone.

\begin{tabular}{|c|c|c|c|c|c|c|c|c|}
\hline & Lithology & T.BRACH & PROD.BRACH & IN.BIV & EPI.BIV & OSMO & GASTRO & CEPHALO \\
\hline RTVA88 & $\mathrm{SH}$ & 0 & 0 & 1 & 2 & 0 & 0 & 0 \\
\hline RTVA92 & LS & 7 & 2 & 1 & 1 & 2 & 0 & 1 \\
\hline RTVA94 & $\mathrm{SH}$ & 0 & 0 & 0 & 0 & 0 & 1 & 0 \\
\hline RTVA96 & LS & 6 & 2 & 2 & 1 & 3 & 1 & 1 \\
\hline RTVA97 & $\mathrm{SH}$ & 0 & 0 & 2 & 2 & 0 & 1 & 1 \\
\hline CFL & $\mathrm{SH}$ & 7 & 2 & 3 & 2 & 3 & 0 & 0 \\
\hline BRB5 & $\mathrm{SH}$ & 3 & 2 & 1 & 1 & 0 & 1 & 1 \\
\hline BRB6 & MS & 3 & 2 & 3 & 1 & 0 & 1 & 0 \\
\hline BRB7 & LS & 3 & 1 & 0 & 0 & 2 & 0 & 0 \\
\hline BRB8 & LS & 2 & 1 & 0 & 0 & 1 & 0 & 0 \\
\hline BRB10 & MS & 1 & 1 & 0 & 0 & 0 & 0 & 0 \\
\hline BRB12 & $\mathrm{SH}$ & 4 & 3 & 0 & 0 & 4 & 0 & 0 \\
\hline BRB13 & LS & 4 & 1 & 1 & 0 & 1 & 0 & 0 \\
\hline PIPE63 & LS & 1 & 0 & 0 & 0 & 0 & 0 & 0 \\
\hline PIPE66 & $\mathrm{SH}$ & 0 & 0 & 1 & 3 & 0 & 0 & 0 \\
\hline PIPE67 & MS & 5 & 2 & 0 & 0 & 3 & 1 & 0 \\
\hline PIPE68 & LS & 3 & 2 & 2 & 2 & 1 & 1 & 0 \\
\hline PIPE71 & $\mathrm{SH}$ & 4 & 1 & 1 & 0 & 1 & 0 & 0 \\
\hline INT56 & $\mathrm{SH}$ & 0 & 0 & 2 & 0 & 0 & 0 & 0 \\
\hline INT62 & $\mathrm{SH}$ & 1 & 0 & 1 & 0 & 0 & 0 & 0 \\
\hline INT63 & $\mathrm{SH}$ & 0 & 0 & 2 & 4 & 0 & 3 & 1 \\
\hline INT64 & LS & 3 & 3 & 0 & 0 & 2 & 1 & 0 \\
\hline INT66 & LS & 0 & 1 & 0 & 1 & 0 & 0 & 1 \\
\hline
\end{tabular}




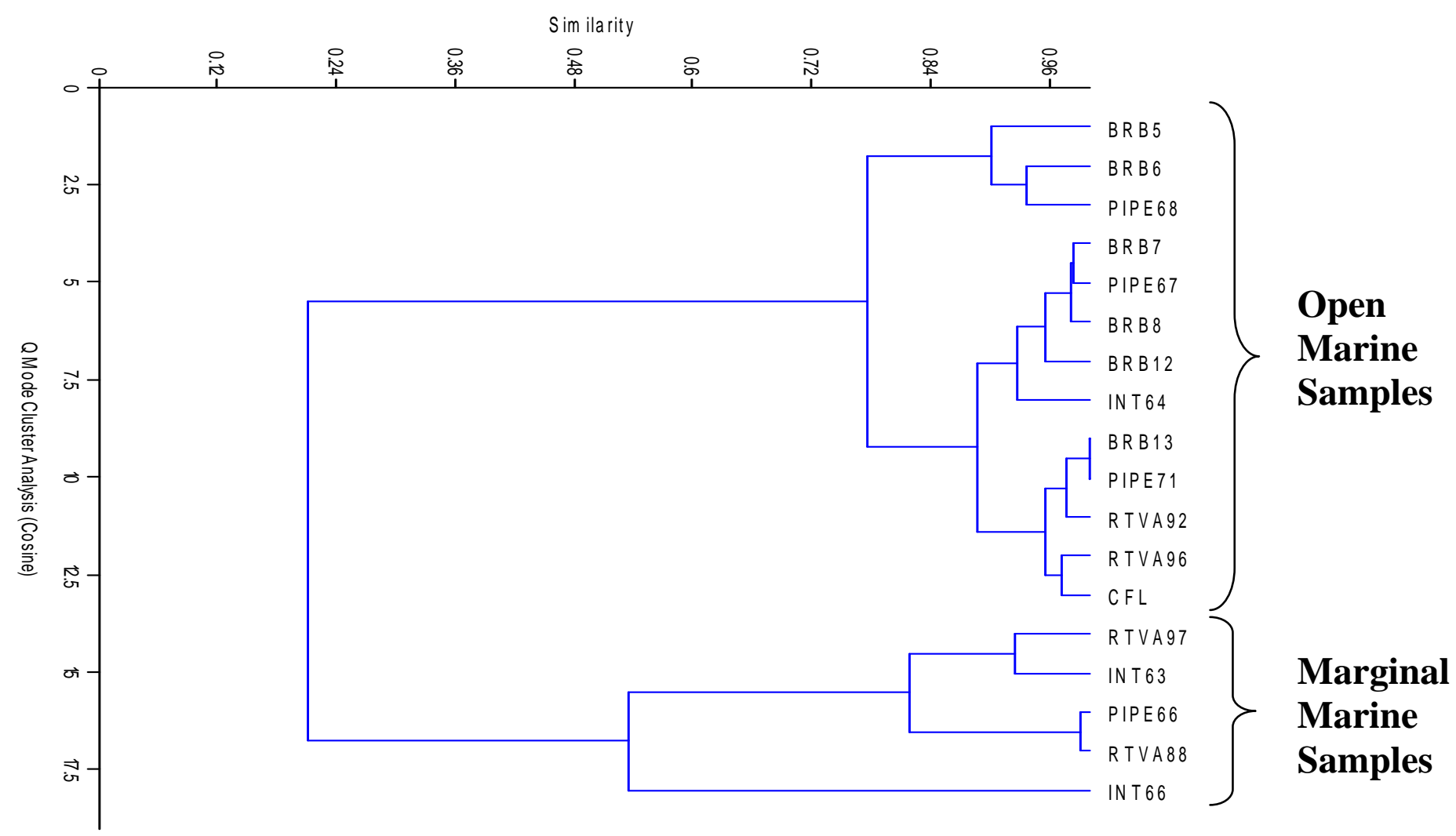

Figure 19. Cluster analysis of Eads Mill Member samples containing three or more taxa using the cosine theta coefficient. Marginal marine samples encompass both transitional and brackish conditions. Open marine samples are indicative of stenohaline conditions. Locality abbreviations are as follows: RTVA- Rt. 102, VA; CFL- Christian Fork Lake; BRB- Bluestone River Bridge; PIPE- Pipestem Creek; INT- Interstate 64. Numbers next to each outcrop abbreviation correspond to specific sampling units on the stratigraphic column for each locality. 


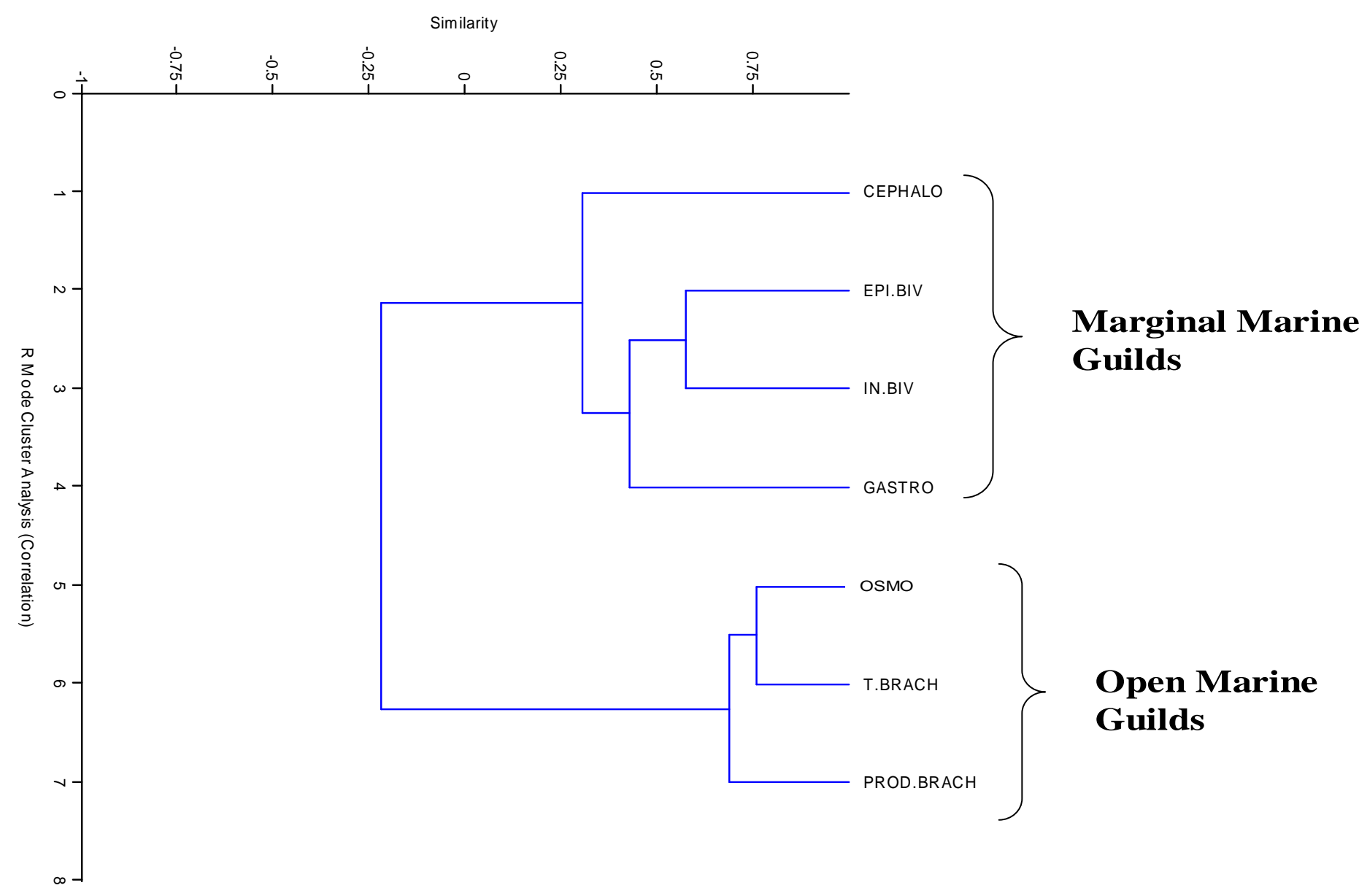

Figure 20. Cluster analysis illustrating similarities between guilds based on their salinity tolerances, using the correlation coefficient. 


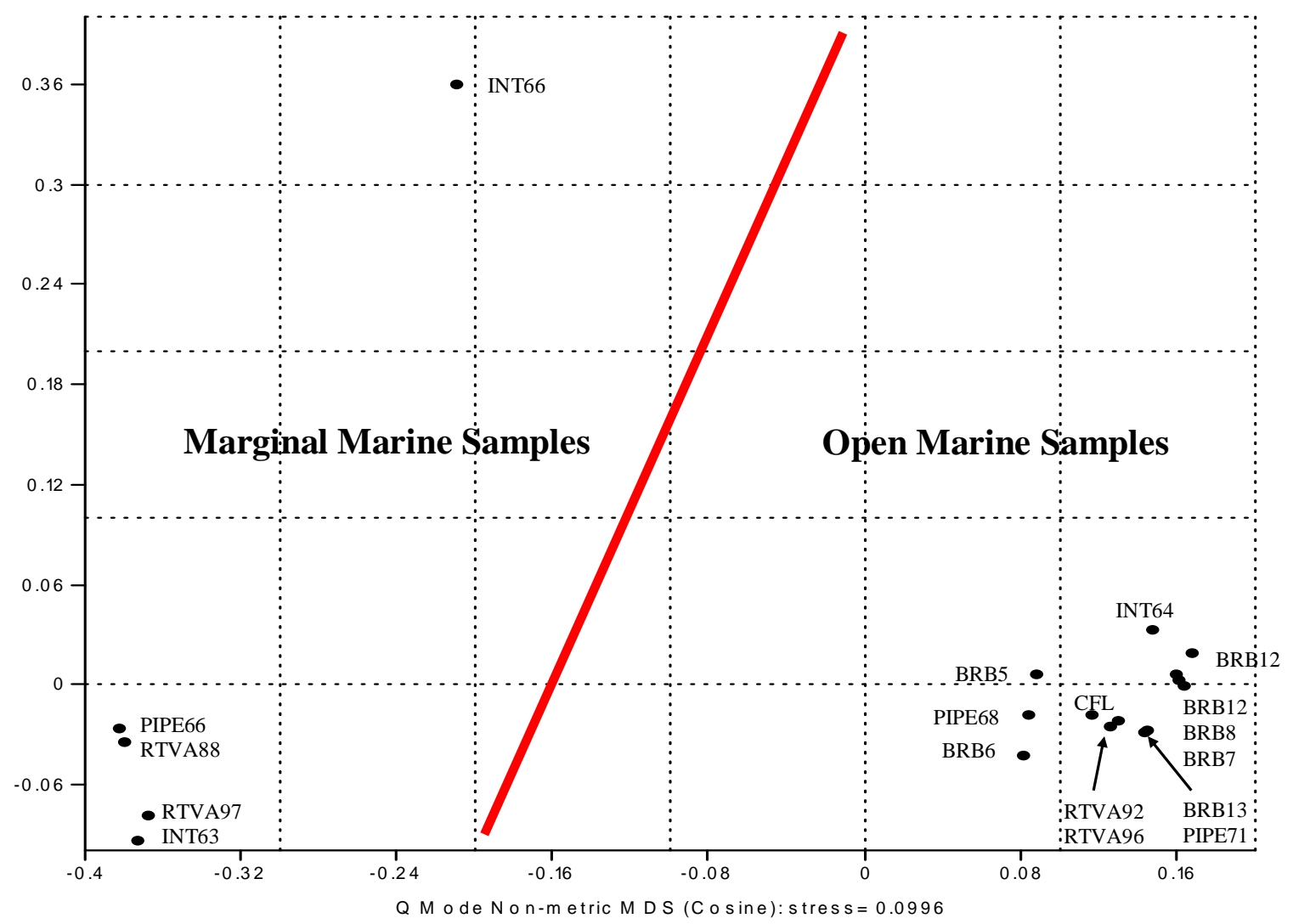

Figure 21. Non-metric MDS analysis showing the distinct separation of samples by salinity tolerance. Both the marginal marine and open marine samples form identical groupings as those illustrated in Figure 19. Open marine samples are closely associated to each other, while the marginal marine samples show a tight grouping of four units, with sample INT66 also being marginal in nature but having a loose association to the others. 


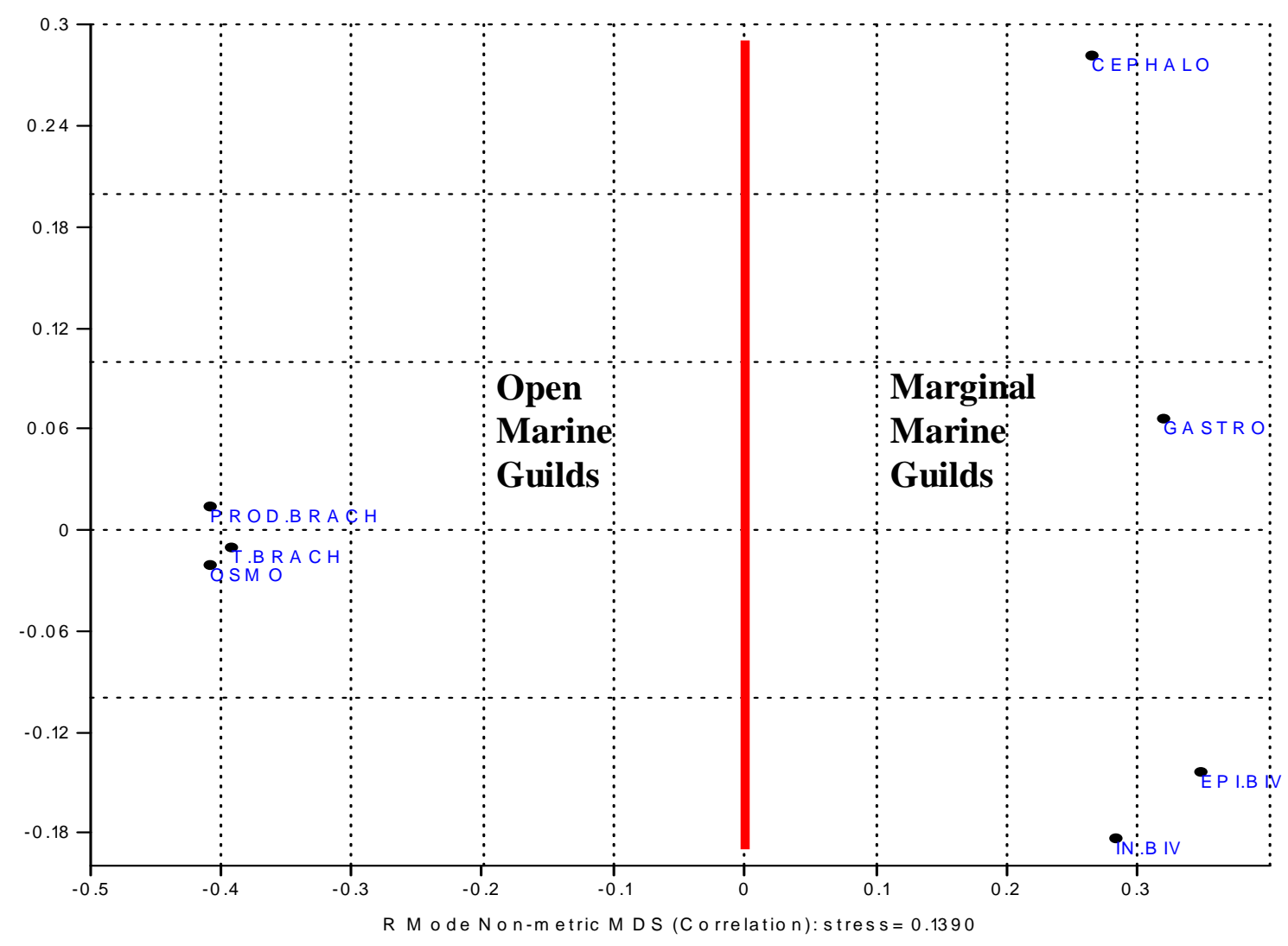

Figure 22. Non-metric MDS showing separation of guilds into open marine and marginal marine based on salinity tolerances. Open marine and marginal marine guilds form identical grouping as those illustrated in Figure 20 using cluster analysis. 


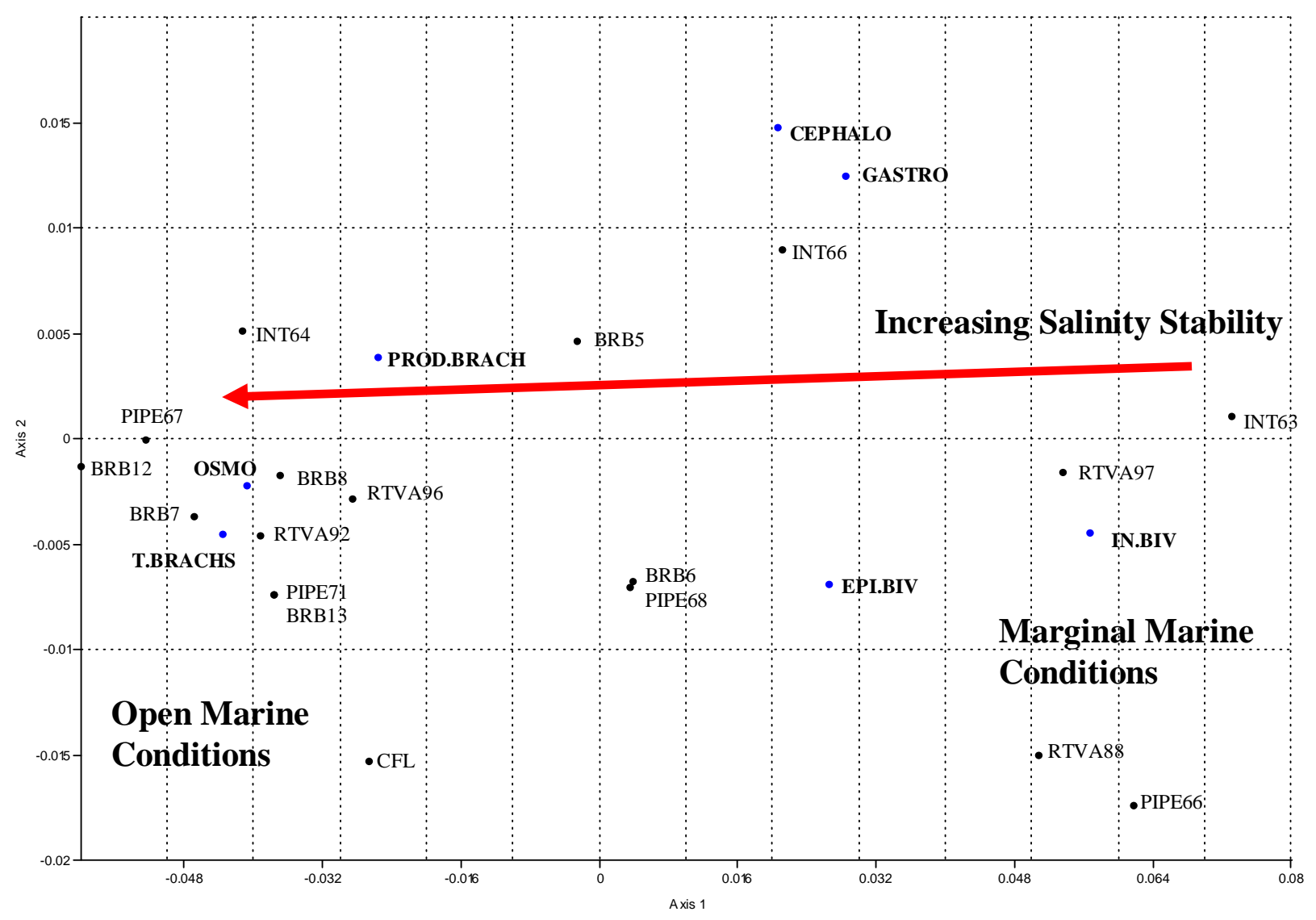

Figure 23. Correspondence analysis illustrating the relationships between Eads Mill samples and guilds. The largest numbers of samples contain open marine taxa as previously shown in the Q-mode cluster analysis, thereby plotting in close association to one another. The lesser number of more widely distributed samples represent marginal marine conditions and are dominated by bivalves. Salinity stability increases moving from marginal marine to open marine conditions as freshwater influx and mixing decrease farther seaward. 


\section{Results and Discussion}

\subsection{Stratigraphic Analysis}

The Eads Mill Member was formed during a transgression and regression cycle driven by eustatic sea level change, with lesser variations noted in some outcrops. The base of the Eads Mill Member is marked by the transition from non-marine shales and paleosols into marine shales or sandstones, usually evidenced by the presence of bivalves in the described sections containing the complete Eads Mill Member. In all complete sections a thick marine shale was deposited during the transgression, some of which contained thin interbedded limestones. Generic diversity increased at the top of the shale and into the lower limestone that is mappable across all complete outcrops (Figure 14). This limestone marks the maximum transgressive surface of the initial sea level rise.

A regression renewed clastic influx to the area, depositing a thick shale above the lower limestone. Another transgression at the top of the shale deposited a second laterally extensive limestone that again marks the maximum transgressive surface and deposition farthest away from clastic influx at the paleoshoreline. A regression above the upper limestone deposited another thick shale across the area. At Bluestone River Bridge and I64, thinner limestones are interbedded near the top of the shale indicating times of local sediment starvation. The regression at the top of the Eads Mill Member transitioned deposition back to coastal facies with the formation of channel sandstones, shales, and thin impure coals, thus marking the end of the Eads Mill Member deposition. The conglomeratic Princeton Sandstone unconformably truncates the underlying deposits and forms the upper contact of the Eads Mill Member at Pipestem Creek. The Princeton 
Sandstone, which forms an unconformable sequence boundary between itself and the Hinton Formation, indicates continued regression after the Eads Mill Member transgressive event (Englund et al., 1986).

\subsection{Multivariate Analysis}

In Figures 19 and 20, cluster analysis yielded two distinct groupings for both Q and R-mode data. The separation of guilds and samples into two groupings is interpreted to be caused by differences in salinity. Both figures confirm that the marginal marine samples and guilds interpreted as being euryhaline plot closest together, as do the open marine samples and guilds identified as being stenohaline. This interpretation is based on the known life habits and salinity tolerances of the taxa contained within each guild (Fursich, 1993, Hudson et al., 1995, Kammer and Lake, 2001, Lebold and Kammer, 2006). Non-metric MDS charts in Figures 21 and 22 also illustrate significant dichotomy within the data, further reinforcing the results of cluster analysis. The combined correspondence analysis plot in Figures 23 contains a readily identifiable trend across each chart, illustrating the strong influence of salinity on the distribution of the guild and sample data. Overall, all three multivariate techniques demonstrate the same pattern of

grouping both the Q and R-mode data, which shows that the underlying paleoecological signal affecting the Eads Mill Member is strong. Many of the taxa within each guild are found in multiple lithofacies within each outcrop, (i.e., brachiopods in limestone, mudstone and shale at the Bluestone River Bridge outcrop and the cephalopod Reticycloceras in a shale and limestone at both the I-64 and Rt. 102 VA outcrops). 
Substrate preferences or the abundance of clastic material were not environmental factors controlling taxonomic distribution (Fursich, 1993). Oxygen availability was also not a factor because very few specimens were pyritized, and none of the taxa were stunted. Thus the underlying control on Eads Mill faunas is interpreted to have been the salinity tolerances of the taxa contained within each guild.

\subsection{Eads Mill Member Paleoecology}

The Eads Mill Member represents a major marine transgression during deposition of the terrestrially dominated upper Hinton Formation. In the early stages of sea level rise, nearshore sandstones and shales were deposited on top of terrestrial paleosols. Brackish conditions formed from the mixing of saline marine water and freshwater from land. The only taxa that could tolerate the fluctuating salinities encountered in this shallow, nearshore environment were bivalves, gastropods and cephalopods (Figures 20, 22). As transgression continued, the volume of freshwater able to reach the depositional area was reduced. When the sea transgressed enough to form normal marine conditions stenohaline taxa of brachiopods, fenestrate bryozoans, and crinoids moved into the area during deposition of the lower (Pluto) limestone (Figure 14). Because they were better suited for normal marine salinities, the stenohaline taxa became the dominant organisms in the ecosystem.

After the maximum transgressive surface was reached, clastic influx was renewed and mud began to fill the basin depositing a thick gray shale above the lower limestone. 
The few genera found in the shale were bivalves, gastropods, cephalopods, and a single occurrence of the brachiopod Lingula. When combined with the presence of siderite bands at I-64 (Figure 13, units 62, 63), this indicates that the shale was either deposited in a freshwater bay or a restricted nearshore environment that contained low levels of sulfate in the sediment (Postma, 1982; Bailey et al., 1998).

The upper (Terry) limestone atop the shale marks the second maximum transgressive surface, which contains predominantly stenohaline taxa is deposited in all five outcrops. As in the lower RTVA92 limestone, brachiopods, fenestrate bryozoans, and crinoids dominated the open marine conditions, along with the first occurrence of rugose corals. This limestone contains the highest taxonomic diversity of any of the samples. It includes taxa from all seven guilds, and also the only two specimens of trilobites found within the Eads Mill. While some euryhaline genera were still present in the stenohaline environment, their percent abundance was greatly decreased. For example, $100 \%$ of the taxa in the RTVA97 mudstone sample are euryhaline (Table 2), as compared to only 35\% in the underlying RTVA96 limestone sample, which is the most taxonomically diverse unit in the Eads Mill Member. At Pipestem Creek, euryhaline genera comprise only $9 \%$ of taxa when found in association with rugose corals and crinoids in PIPE67, yet with the absence of those to taxa in the overlying PIPE68 sample, euryhaline taxa make up 50\%. This may indicate that the stenohaline genera were better suited to open marine conditions and out-competed the euryhaline genera for resources. 
The shoreline regressed after deposition of the upper limestone unit, and fine clastic sediment again filled the basin. As before, the taxa were dominated by the euryhaline guilds, with a few rare brachiopod occurrences. The presence of siderite at the Rt. 102 and I-64 outcrops indicates that the shale at these localities was deposited in brackish nearshore conditions. Shoreline regressed for the remainder of the Eads Mill Member, creating euryhaline marginal marine conditions at Rt. 102, Pipestem Creek and I-64. Open marine conditions persisted longer at Bluestone River Bridge and Christian Fork Lake because they were apparently deposited farther away from freshwater influx than the rest of the Eads Mill Member outcrops, as indicated by the presence of stenohaline open marine taxa near the top of each outcrop (Figures 7, 9). Regression continued until terrestrial facies were again deposited, as indicated by the thin impure coal at the top of the Rt. 102 VA section.

A fourth multivariate technique using guild binary data further illustrates the transgressive/ regressive cycle that deposited the Eads Mill Member. Detrended correspondence analysis (DCA) methods which remove the arch effect found in correspondence analysis, have been previously employed by Scarponi and Kowalewski (2004) to determine sea level fluctuations based on estimated water depth. Figures 25 and 26 employ similar techniques but for relative water depth, and the results illustrate the overall transgressive / regressive cycle that deposited the Eads Mill Member. The base of the Eads Mill Member was deposited during the beginning transgression, which initially formed nearshore, marginal marine facies on top of underlying terrestrial deposits. As the transgression proceeded, water depth and the resulting salinity increased, forming open 
marine conditions suitable for habitation by stenohaline taxa. The shift from brackish marine conditions into an open marine environment occurs when moving from higher to lower DCA Axis 1 (DCA1) values (Figure 24). The first maximum transgressive surface is marked by the deposition of the lower limestone. After deposition of the lower thick shale, the upper limestone which is correlated across four complete sections in Figure 25 was deposited. This limestone marks the second maximum transgressive surface within the Eads Mill Member. Except at Pipestem Creek where the Princeton Sandstone truncates the top of the Eads Mill Member, the Rt. 102 VA and I-64 outcrops record a regression after deposition of the upper limestone. Marginal marine conditions were reestablished and eventually terrestrial facies were deposited, as shown by the channel sandstone and thin coal at the top of the Rt. 102 Virginia locality (Figure 6). As previously noted the Bluestone River Bridge and Christian Fork Lake outcrops represent the most stable marine depositional environment. When compared to the other outcrops in Figure 26, the Bluestone River Bridge locality is the only one that represents complete open marine deposition. It reaches and maintains the most negative DCA1 values of all outcrops plotted, indicating that open marine conditions persisted for an extended period of time. This further supports the proposal that both the Bluestone River Bridge and Christian Fork Lake outcrops, which are nearly taxonomically identical, were deposited in stable marine conditions farthest from the paleoshoreline. 


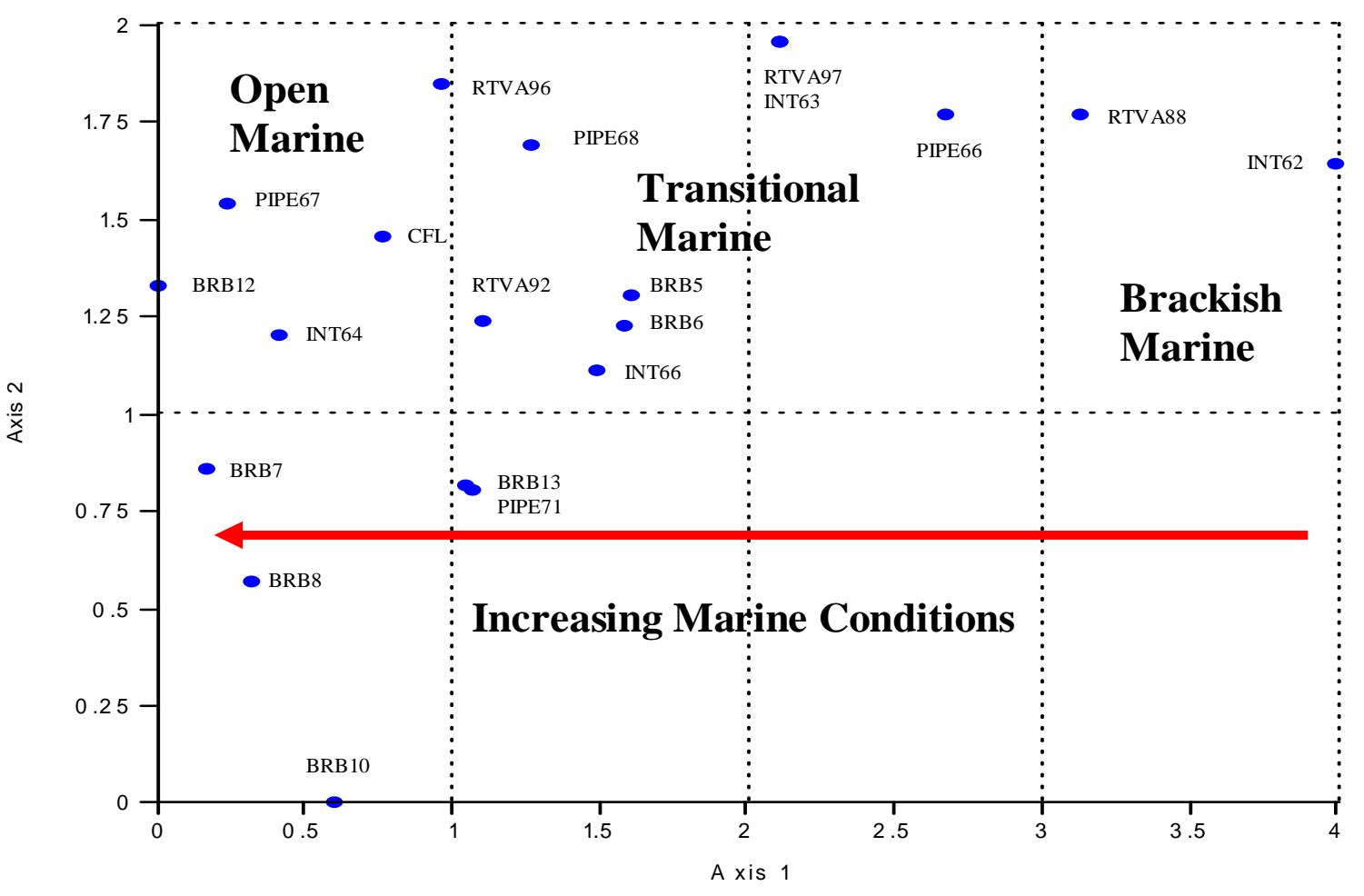

Figure 24. Detrended correspondence analysis (DCA1) of the Eads Mill Member's Q-mode data (Table 5). This plot illustrates that the Eads Mil Member is dominated by open marine samples, with fewer transitional and brackish marine units. This indicates that the transgressions that formed the member were laterally extensive, forming open marine conditions during the majority of Eads Mill Member deposition. 

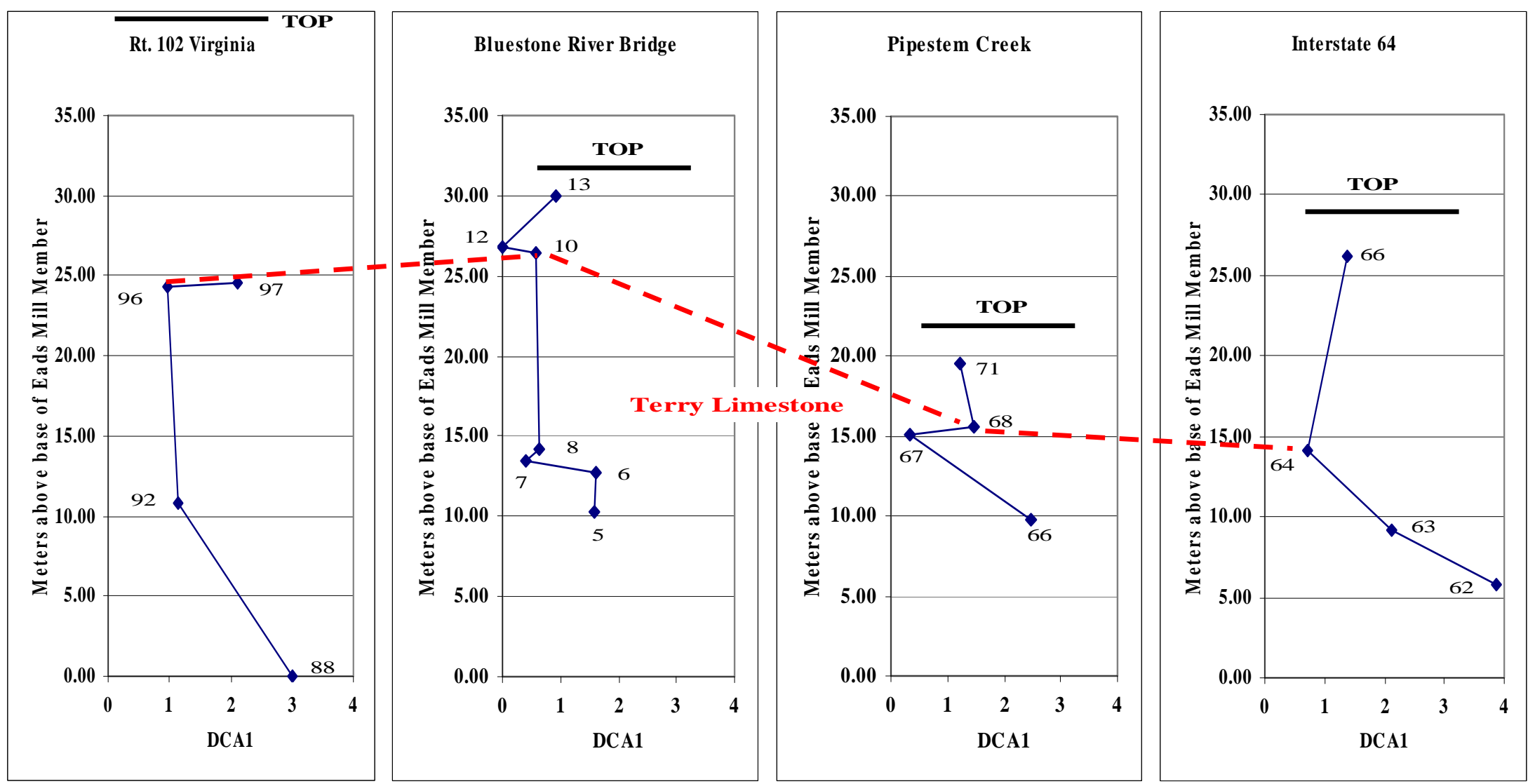

Figure 25. Stratigraphic patterns in DCA1 scores for the most complete Eads Mill Member outcrops using sample scores on Axis 1 of detrended correspondence analysis (DCA1). The bottom of each column marks the identified base of the Eads Mill Member and the top of the Eads Mill Member in each column is represented by a horizontal line. Sample numbers marked on each column correspond to sampled units within each respective stratigraphic column. Values above 2 represent increasingly brackish marine conditions, whereas values below 2 indicate more open marine conditions. The dashed line correlates the Terry Limestone noted in Figure 14, which marks the uppermost maximum transgressive surface. A regression above the Terry Limestone moved the facies back towards brackish marine conditions. 


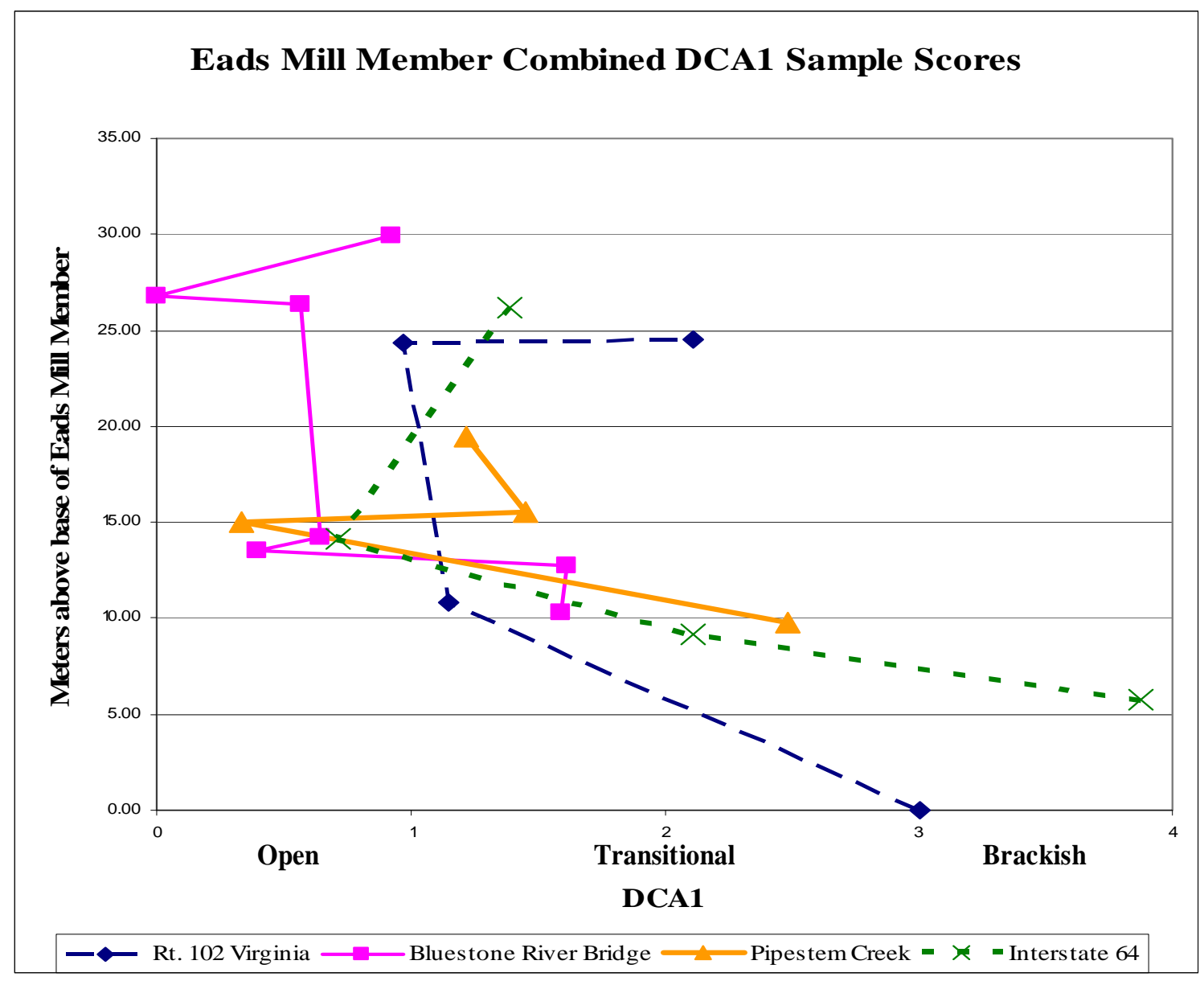

Figure 26. Combined detrended correspondence analysis (DCA1) sample score graphs from Figure 25 for the Eads Mill Member. Each outcrop contains a transgression from transitional to brackish conditions at the base to open marine in the middle, and then a regression towards brackish at the top. This figure also illustrates that the Bluestone River Bridge locality preserves the most open marine conditions of all outcrops, indicating that it was deposited farthest from the paleoshoreline. 
Overall, the Eads Mill Member represents a period of marginal to open marine conditions that existed during the deposition of the terrestrially dominated upper Hinton Formation. The distribution of fossil taxa within the sampled outcrops was controlled by their proximity to the paleoshoreline and its resulting effect on water salinity. The samples deposited closest to shore contain taxa characteristic of marginal marine environments, such as bivalves, gastropods, and cephalopods (Figures 20,22). These euryhaline conditions were formed when terrestrial freshwater mixed with the saline sea water near the shoreline. Because of the variability of freshwater influx, only those taxa that actively regulate the amount of salt in their cells could survive (Fursich, 1993). As the shoreline moved farther away, the zone of mixing diminished and eventually disappeared. Stenohaline taxa that were better suited to normal marine salinities populated the seafloor in great abundance. While this decreased the percent abundance of euryhaline specimens that could also live in the stenohaline conditions it increased the overall taxonomic diversity, especially in the laterally continuous upper limestone. This shows that the euryhaline guilds were generalists and could survive in all salinity ranges, whereas the stenohaline guilds were specialists and required stable open marine conditions in order to live. Thus salinity is determined to be the most influential environmental factor, and its robust signal is readily identifiable in generic presence/ absence data and multivariate analyses conducted during this study. 


\subsection{Upper Hinton Formation Marine Paleoecology}

Data from this and a concurrent study of the underlying Fivemile Member of the upper Hinton Formation (Figure 4) conducted by my fellow graduate student Tom Cawthern were combined and analyzed to ascertain any overall depositional pattern for the two members. Samples that contained more than one taxon were included in the data. Twelve guilds were constructed for the combined data set: three new guilds for ostracods, trilobites and the brachiopod Lingula; separation of the taxa (rugose corals, crinoids, and bryozoans) previously combined into the osmo-conformer guild of the Eads Mill Member; and the six remaining guilds of the Eads Mill Member (Table 6). Q and R-mode data were analyzed using three of the four multivariate techniques previously employed with the Eads Mill Member: cluster analysis (Figures 27, 28), non-metric MDS (R-mode only, Figure 29), and DCA1 (Figures 30, 31). Samples and guilds were grouped into three categories based on paleosalinity: brackish marine conditions (5-30\%), transitional marine conditions (30\%), and open marine conditions (35\%). A bar graph illustrating the twelve guilds' DCA1 values (Figure 32), and a combined DCA1 sample score graph for both the Fivemile and Eads Mill Member (Figure 33) was also created. The resulting plots reinforce the conclusion that the proximity to shoreline and the corresponding salinity was the primary factor controlling the distribution of taxa in marine zones of the upper Hinton Formation. 
Table 6. Part 1: Binary guild data for the Eads Mill Member (Part 1) and the Fivemile Member (Part 2). Total abundance for each guild is calculated along the bottom, and total guild richness for each sample is calculated along the side. The combined guild abundance for both members is located at the bottom of the second half of the table.

\begin{tabular}{|c|c|c|c|c|c|c|c|c|c|c|c|c|c|}
\hline $\begin{array}{l}\text { Locality } \\
\text { and } \\
\text { sample } \\
\text { number }\end{array}$ & Guild & & & & & & & & & & & & Sum \\
\hline & $\begin{array}{c}\text { T- } \\
\text { Brachs }\end{array}$ & Lingula & P-Brachs & Epi-Biv & In-Biv & Gastropods & Nautiloid & Trilobote & Bryozoans & Crinoids & $\begin{array}{l}\text { Rugose } \\
\text { Corals }\end{array}$ & Ostracod & Sum \\
\hline RTVA88 & 0 & 0 & 0 & 1 & 1 & 0 & 0 & 0 & 0 & 0 & 0 & 1 & 3 \\
\hline RTVA92 & 1 & 0 & 1 & 1 & 1 & 0 & 1 & 0 & 1 & 1 & 0 & 0 & 7 \\
\hline RTVA96 & 1 & 0 & 1 & 1 & 1 & 1 & 1 & 1 & 1 & 1 & 1 & 0 & 10 \\
\hline RTVA97 & 0 & 0 & 0 & 1 & 1 & 1 & 1 & 0 & 0 & 0 & 0 & 0 & 4 \\
\hline CFL & 1 & 0 & 1 & 1 & 1 & 0 & 0 & 0 & 1 & 1 & 1 & 0 & 7 \\
\hline BRB5 & 1 & 0 & 1 & 1 & 1 & 1 & 1 & 0 & 0 & 0 & 0 & 0 & 6 \\
\hline BRB6 & 1 & 0 & 1 & 1 & 1 & 1 & 0 & 0 & 0 & 0 & 0 & 0 & 5 \\
\hline BRB7 & 1 & 0 & 1 & 0 & 0 & 0 & 0 & 0 & 1 & 1 & 0 & 0 & 4 \\
\hline BRB8 & 1 & 0 & 1 & 0 & 0 & 0 & 0 & 0 & 1 & 0 & 0 & 0 & 3 \\
\hline BRB10 & 1 & 0 & 1 & 0 & 0 & 0 & 0 & 0 & 0 & 0 & 0 & 0 & 2 \\
\hline BRB12 & 1 & 0 & 1 & 0 & 0 & 0 & 0 & 0 & 1 & 1 & 1 & 0 & 5 \\
\hline BRB13 & 1 & 0 & 1 & 1 & 0 & 0 & 0 & 0 & 0 & 1 & 0 & 0 & 4 \\
\hline PIPE66 & 0 & 0 & 0 & 1 & 1 & 0 & 0 & 0 & 0 & 0 & 0 & 0 & 2 \\
\hline PIPE67 & 1 & 0 & 1 & 0 & 0 & 1 & 0 & 0 & 1 & 1 & 1 & 0 & 6 \\
\hline PIPE68 & 1 & 0 & 1 & 1 & 1 & 1 & 0 & 1 & 1 & 0 & 0 & 0 & 7 \\
\hline PIPE71 & 1 & 0 & 1 & 1 & 0 & 0 & 0 & 0 & 1 & 0 & 0 & 0 & 4 \\
\hline INT62 & 0 & 1 & 0 & 1 & 0 & 0 & 0 & 0 & 0 & 0 & 0 & 0 & 2 \\
\hline INT63 & 0 & 0 & 0 & 1 & 1 & 1 & 1 & 0 & 0 & 0 & 0 & 0 & 4 \\
\hline INT64 & 1 & 0 & 1 & 0 & 0 & 1 & 0 & 0 & 1 & 1 & 0 & 0 & 5 \\
\hline INT66 & 0 & 0 & 1 & 0 & 1 & 0 & 1 & 0 & 0 & 0 & 0 & 0 & 3 \\
\hline SUM & 14 & 1 & 15 & 13 & 11 & 8 & 6 & 2 & 10 & 8 & 4 & 1 & \\
\hline
\end{tabular}


Table 6. Part 2

\begin{tabular}{|c|c|c|c|c|c|c|c|c|c|c|c|c|c|}
\hline $\begin{array}{l}\begin{array}{l}\text { Locality } \\
\text { and }\end{array} \\
\text { sample } \\
\text { number }\end{array}$ & Guild & & & & & & & & & & & & Sum \\
\hline & $\begin{array}{c}\text { T- } \\
\text { Brachs }\end{array}$ & Lingula & $\begin{array}{c}\text { P- } \\
\text { Brachs }\end{array}$ & $\begin{array}{l}\text { Epi- } \\
\text { Biv }\end{array}$ & $\begin{array}{l}\text { In- } \\
\text { Biv }\end{array}$ & Gastropods & Nautiloid & Trilobote & Bryozoans & Crinoids & $\begin{array}{c}\text { Rugose } \\
\text { Corals }\end{array}$ & Ostracod & Sum \\
\hline A22 & 0 & 1 & 0 & 1 & 1 & 1 & 0 & 0 & 0 & 0 & 0 & 0 & 4 \\
\hline A24 & 0 & 0 & 0 & 1 & 0 & 0 & 0 & 0 & 0 & 0 & 0 & 1 & 2 \\
\hline A32 & 0 & 0 & 0 & 1 & 0 & 1 & 0 & 0 & 1 & 0 & 0 & 1 & 4 \\
\hline A34 & 0 & 0 & 0 & 1 & 0 & 0 & 0 & 0 & 0 & 0 & 0 & 1 & 2 \\
\hline A35 & 0 & 0 & 0 & 1 & 0 & 0 & 0 & 0 & 0 & 0 & 0 & 1 & 2 \\
\hline A40 & 0 & 1 & 0 & 1 & 0 & 0 & 0 & 0 & 0 & 0 & 0 & 0 & 2 \\
\hline A41 & 0 & 0 & 0 & 1 & 0 & 0 & 0 & 0 & 0 & 0 & 0 & 1 & 2 \\
\hline A45 & 0 & 1 & 0 & 1 & 1 & 0 & 0 & 0 & 0 & 0 & 0 & 1 & 4 \\
\hline A47 & 0 & 0 & 0 & 1 & 0 & 0 & 0 & 0 & 0 & 0 & 0 & 1 & 2 \\
\hline A49 & 0 & 0 & 0 & 1 & 0 & 0 & 0 & 0 & 0 & 0 & 0 & 1 & 2 \\
\hline A53 & 0 & 0 & 0 & 1 & 0 & 0 & 0 & 0 & 0 & 0 & 0 & 1 & 2 \\
\hline B35 & 1 & 0 & 1 & 1 & 1 & 1 & 1 & 1 & 1 & 1 & 0 & 1 & 10 \\
\hline B41 & 0 & 0 & 0 & 1 & 0 & 0 & 0 & 0 & 0 & 0 & 0 & 1 & 2 \\
\hline C33 & 0 & 0 & 0 & 1 & 1 & 0 & 0 & 0 & 0 & 0 & 0 & 1 & 3 \\
\hline C34 & 0 & 0 & 0 & 1 & 0 & 1 & 0 & 0 & 0 & 0 & 0 & 1 & 3 \\
\hline C35 & 0 & 1 & 0 & 1 & 0 & 1 & 0 & 0 & 0 & 0 & 0 & 1 & 4 \\
\hline C38 & 0 & 1 & 0 & 1 & 0 & 0 & 0 & 0 & 0 & 0 & 0 & 1 & 3 \\
\hline C42 & 0 & 1 & 0 & 1 & 1 & 0 & 0 & 0 & 0 & 0 & 0 & 1 & 4 \\
\hline C43 & 0 & 1 & 0 & 1 & 0 & 0 & 0 & 0 & 0 & 0 & 0 & 1 & 3 \\
\hline C44 & 0 & 1 & 0 & 0 & 0 & 0 & 0 & 0 & 0 & 0 & 0 & 1 & 2 \\
\hline D43 & 0 & 0 & 0 & 1 & 0 & 1 & 0 & 0 & 0 & 0 & 0 & 1 & 3 \\
\hline D51 & 0 & 0 & 0 & 1 & 0 & 1 & 0 & 0 & 0 & 0 & 0 & 1 & 3 \\
\hline D52 & 0 & 0 & 0 & 1 & 0 & 0 & 0 & 0 & 0 & 0 & 0 & 1 & 2 \\
\hline D55 & 0 & 0 & 0 & 1 & 0 & 0 & 0 & 0 & 0 & 0 & 0 & 1 & 2 \\
\hline D56 & 0 & 0 & 0 & 1 & 0 & 0 & 0 & 0 & 0 & 0 & 0 & 1 & 2 \\
\hline $\begin{array}{l}\text { SUM } \\
\text { Total }\end{array}$ & 1 & 8 & 1 & 24 & 5 & 7 & 1 & 1 & 2 & 1 & 0 & 23 & \\
\hline Sum & 15 & 9 & 16 & 37 & 16 & 15 & 7 & 3 & 12 & 9 & 4 & 24 & \\
\hline
\end{tabular}




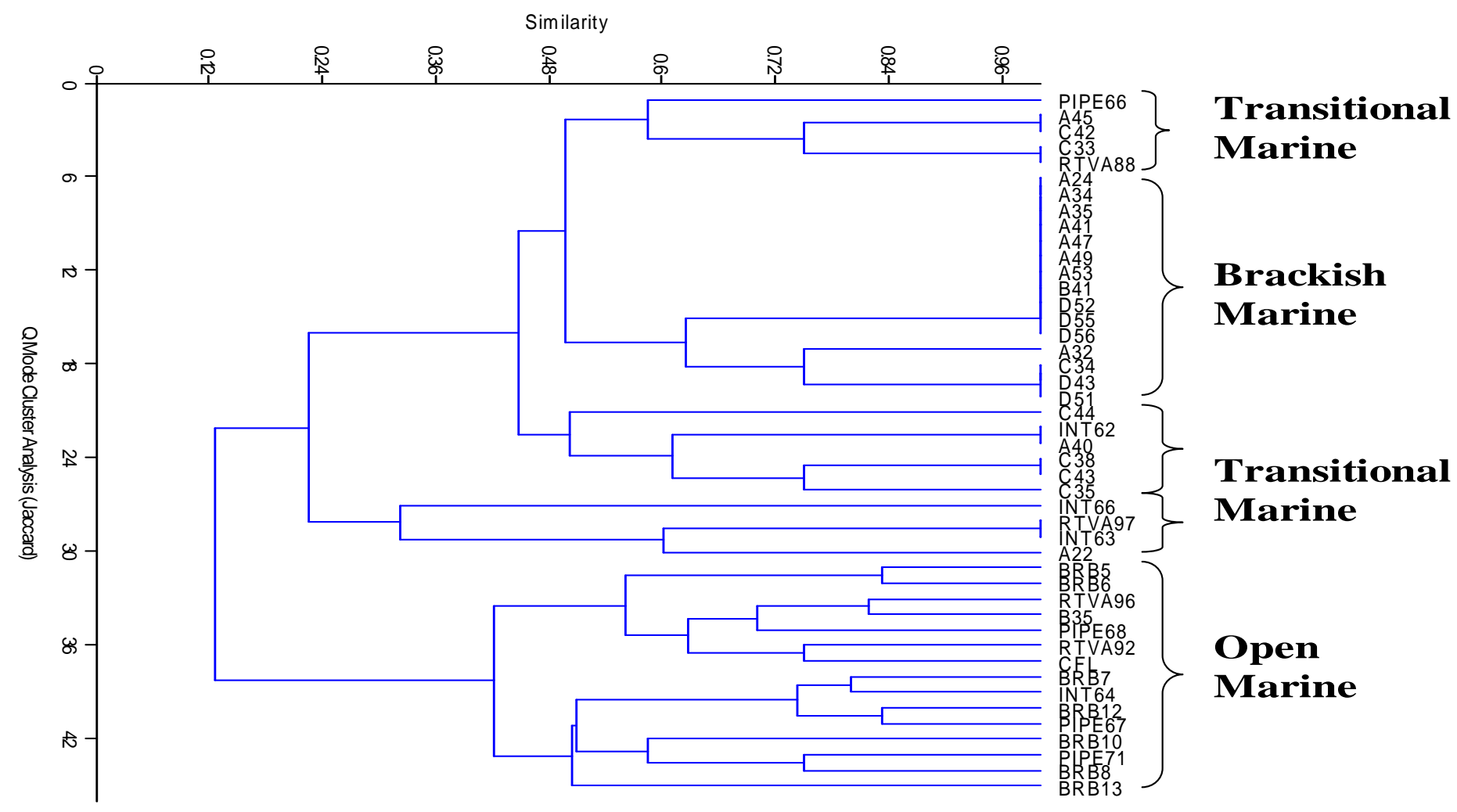

Figure 27. Cluster analysis combining the Fivemile and Eads Mill Members' Q-mode binary data (Table 5) using the Jaccard coefficient. Outcrop labels for the Eads Mill Member are the same as those previously used. The brackish (5-30 \%o) and transitional marine (30\%o) environments are dominated by Fivemile Member samples, with all of the previously identified marginal marine samples (Figures 19, 21) from the Eads Mill Member also being included. The open marine environment contains all of the previously identified open marine samples from the Eads Mill Member, and one (B35) from the Fivemile Member. This cluster analysis illustrates that the Fivemile Member was deposited in predominantly marginal marine conditions (made of brackish and transitional marine environments) where freshwater mixing in a nearshore environment lowered the salinity. In contrast the Eads Mill Member is typified by an open marine environment with normal marine salinities (35 \%o) and no freshwater mixing. 


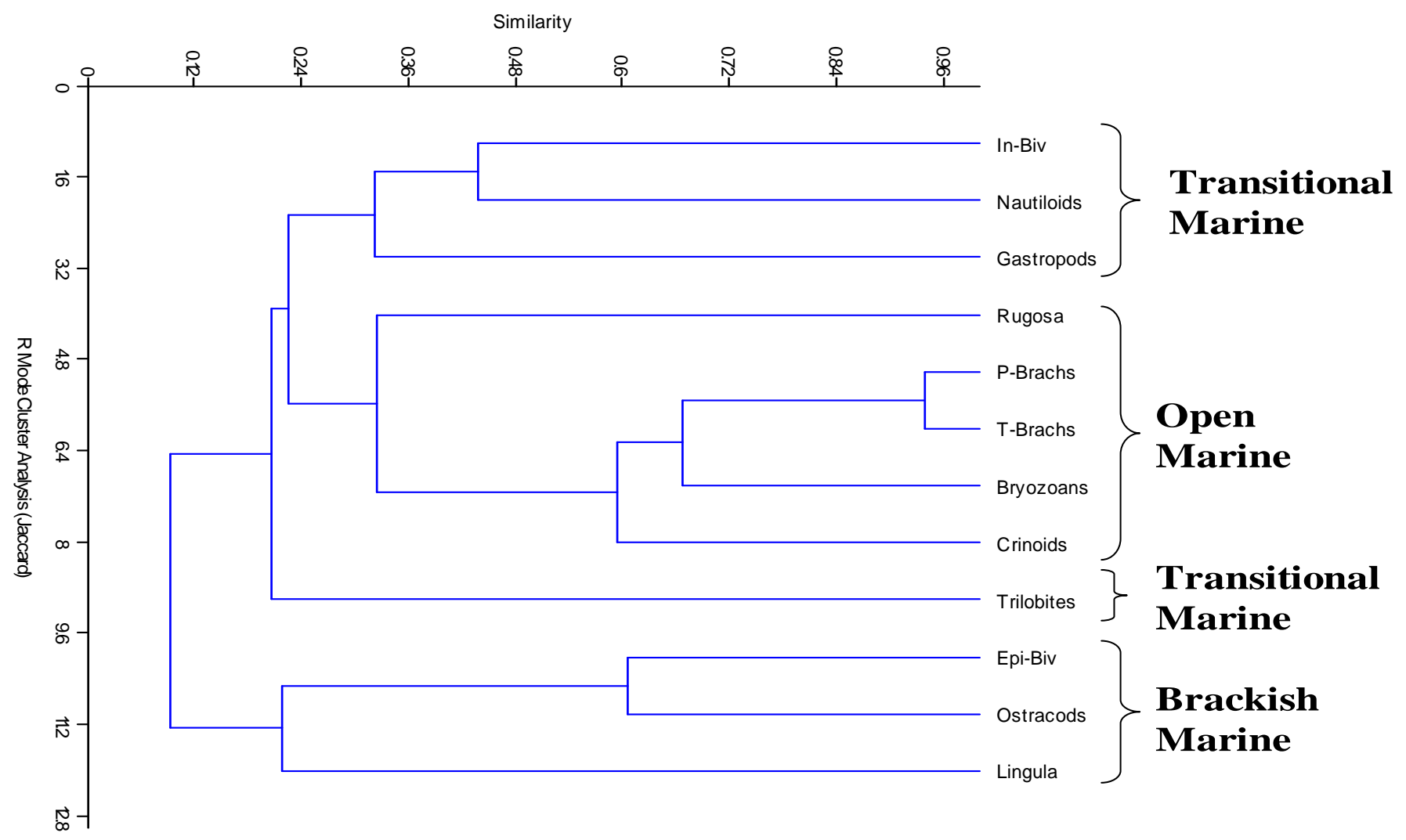

Figure 28. Cluster analysis combining the Fivemile and Eads Mill Members' R-mode binary guild data (Table 5). Grouping of guilds follow the same pattern as the grouping of samples. The Fivemile Member contains the most occurrences of brackish marine taxa, whereas the Eads Mill Member contains the most occurrences of open marine taxa. Both members contain a lesser number of taxa identified as being transitional marine. 


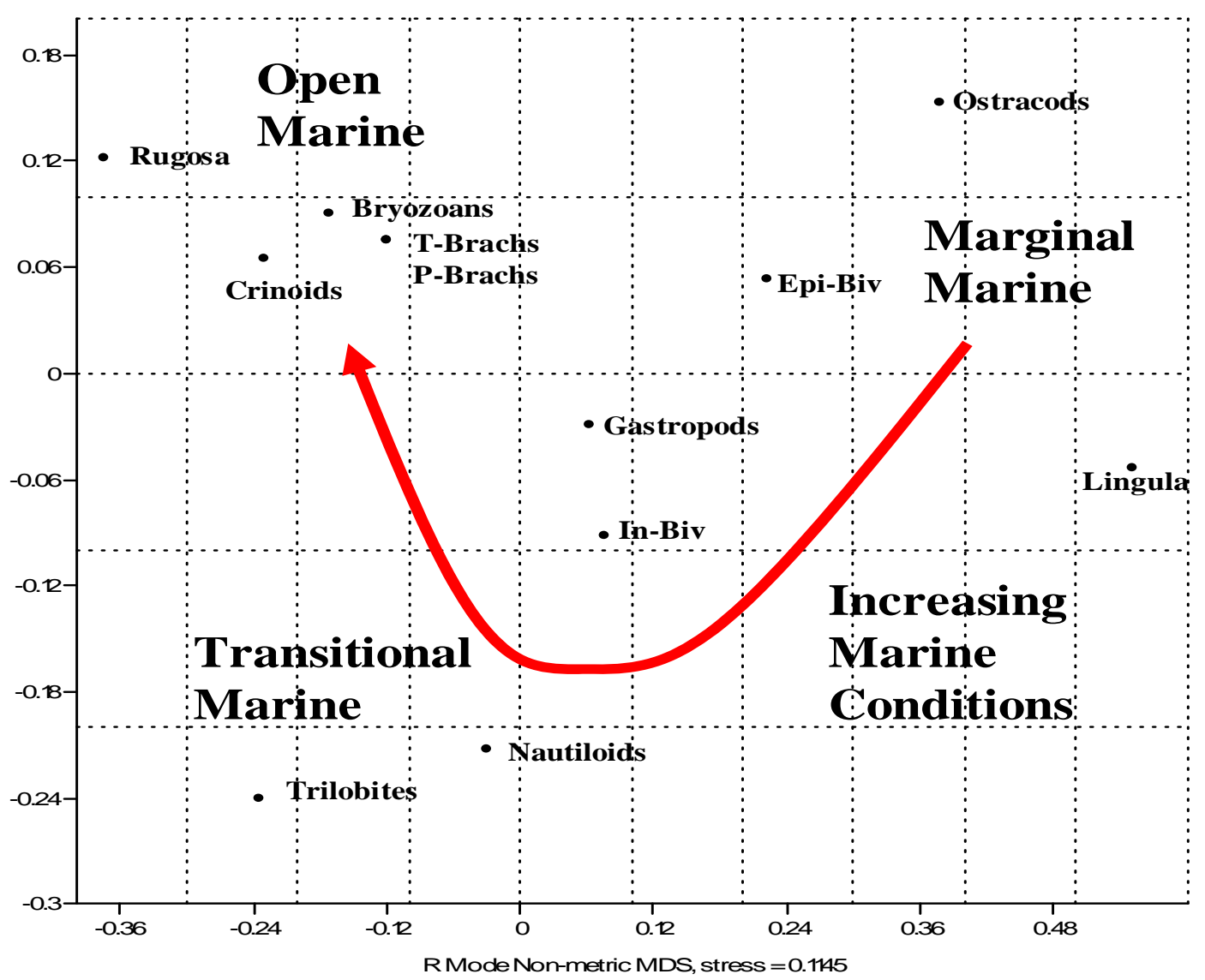

Figure 29. Non-metric MDS chart combining the Fivemile and Eads Mill Members' R-mode data (Table 5). Brackish marine guilds identified in Figure 27 plot together, with a distinct trend showing increasing marine conditions through the transitional marine guilds towards the open marine grouping. 


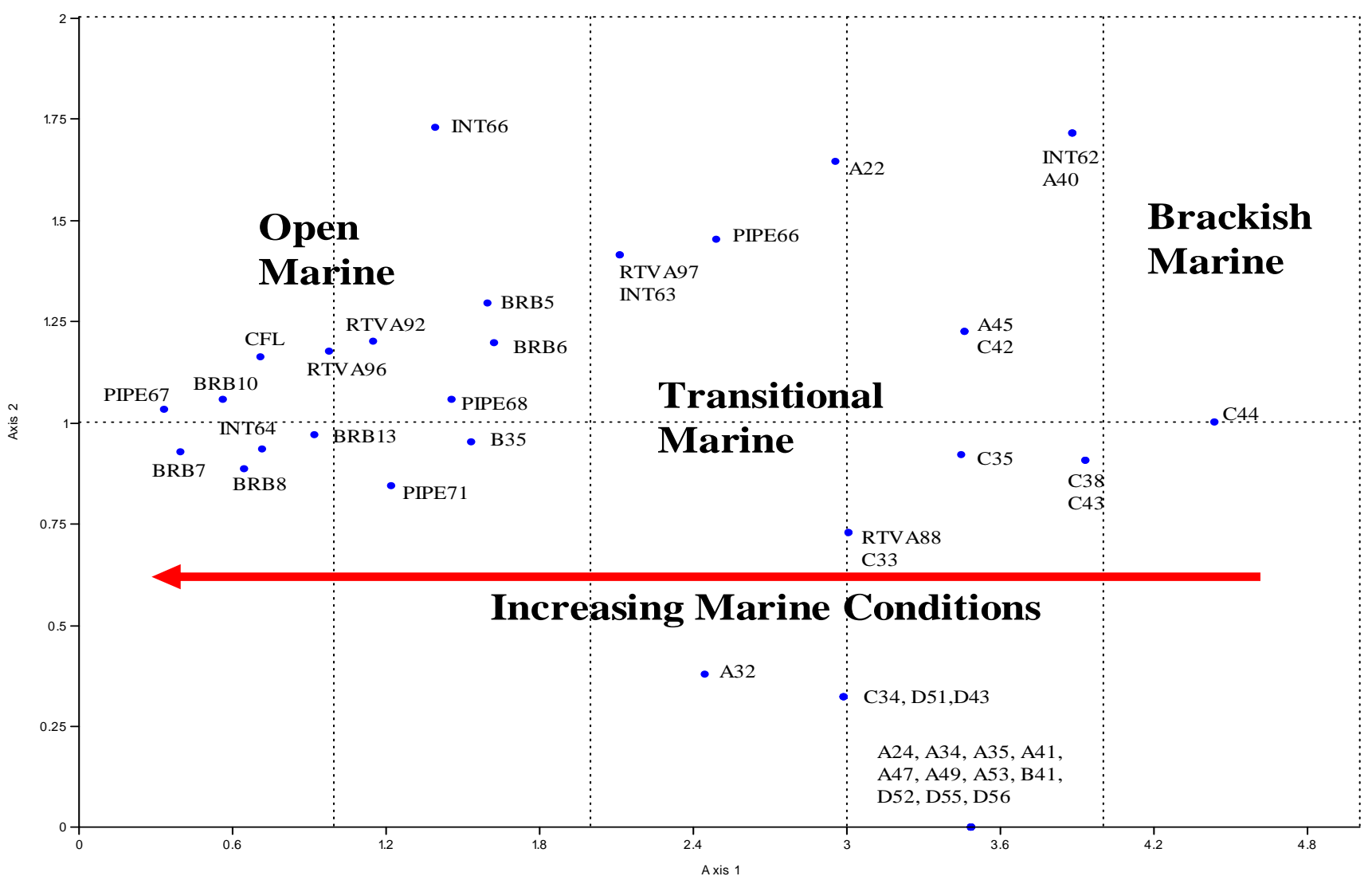

Figure 30. Detrended correspondence analysis (DCA1) of the Fivemile and Eads Mill Members' Q-mode data (Table 5). A distinct trend going from a brackish to an open marine environment along Axis 1 is delineated upon increasing marine conditions. Brackish marine conditions are dominated by Fivemile Member samples. Transitional marine conditions contain both Fivemile and Eads Mill Member samples. The open marine environment is completely represented by Eads Mill Member samples. All carbonate samples contained within both members are located between 0 and 2 on Axis 1 , indicating that carbonate rocks were only able to form in an open marine environment. The BRB12 sample from Table 6 is the most stenohaline unit within the two members, having only brachiopods, crinoids, bryozoans, and rugose corals. Thus is has a highly negative Axis 1 value that does not plot on this graph. 


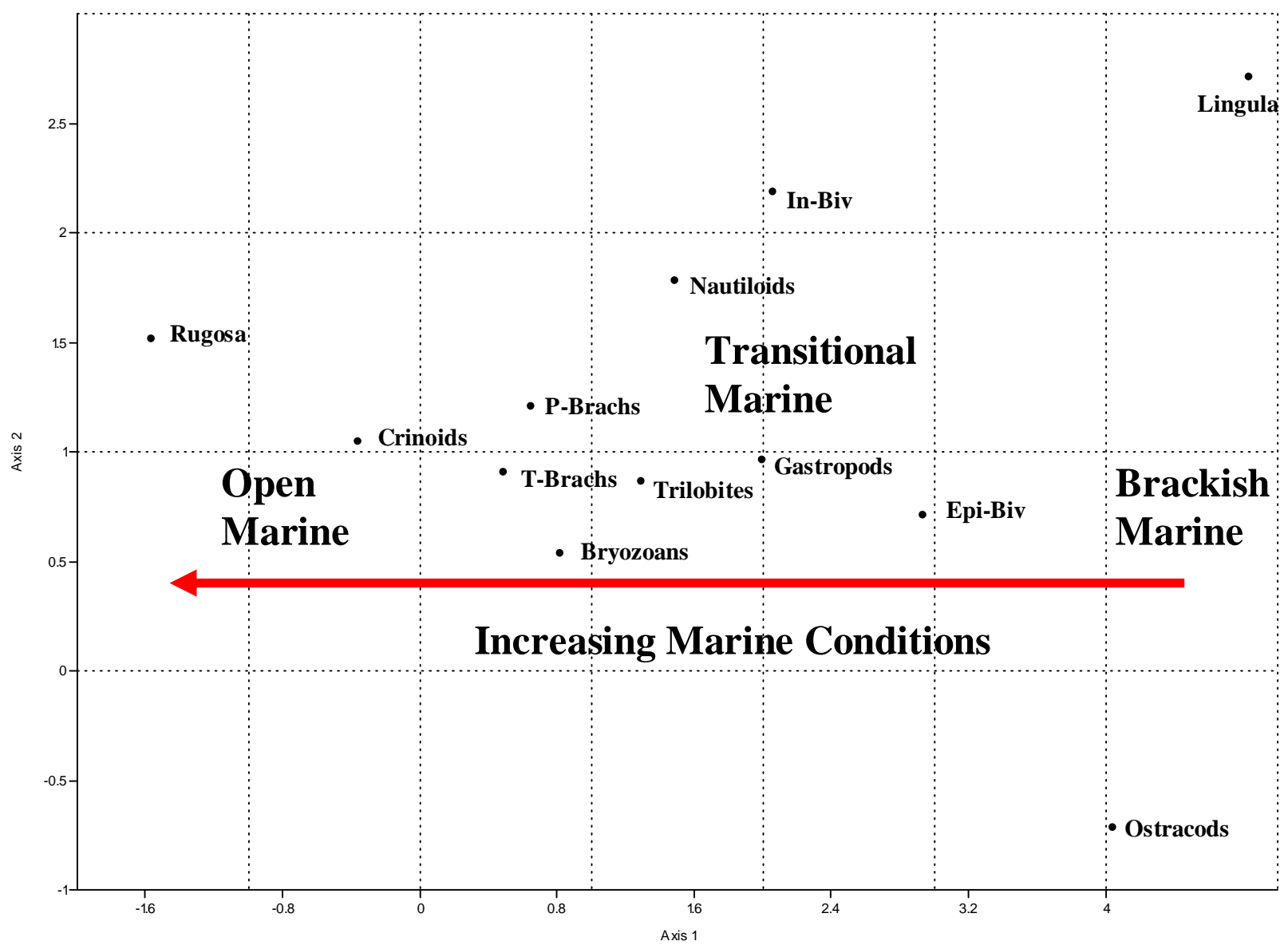

Figure 31. Detrended correspondence analysis (DCA1) of the Fivemile and Eads Mill Members' R-mode data (Table 5). Guilds show a pronounced trend along Axis 1 illustrating increasing marine conditions from brackish to marine environments. Guilds are grouped the same as in Figure 27, and have the same trend as shown in Figure 28. This indicates that salinity formed a strong underlying control in all multivariate techniques. 


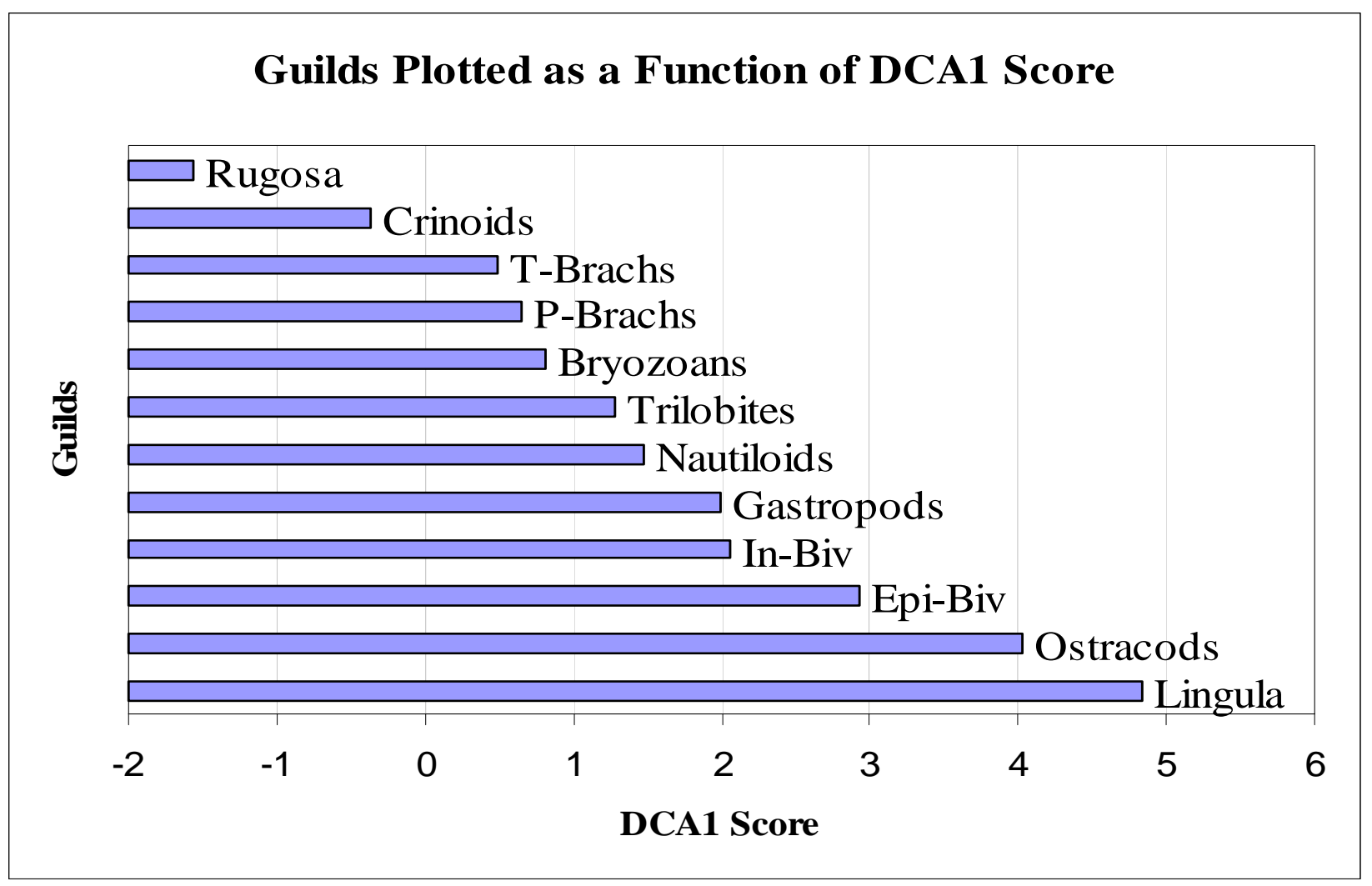

Figure 32. Bar graph illustrating the distribution of the 12 guilds in both the Fivemile and Eads Mill Members based on their Axis 1 detrended correspondence analysis (DCA1) scores. The results, which are identical to those in Figure 30, demonstrate the same grouping based on environmental conditions. All of the open marine guilds plot below 1, with the most stenohaline guilds (Rugosa and Crinoids) having negative DCA1 values. The transitional marine guilds identified in Figure 27 plot together, but are more closely associated to the open marine guilds than those in the brackish marine. This verifies the conclusion that the salinity in the transitional marine environment, at $30 \%$, is very close to that found in completely open marine conditions. The three brackish marine guilds show a distinct separation from the open and transitional marine guilds indicative of a sharp decrease in salinity present in brackish marine conditions. 


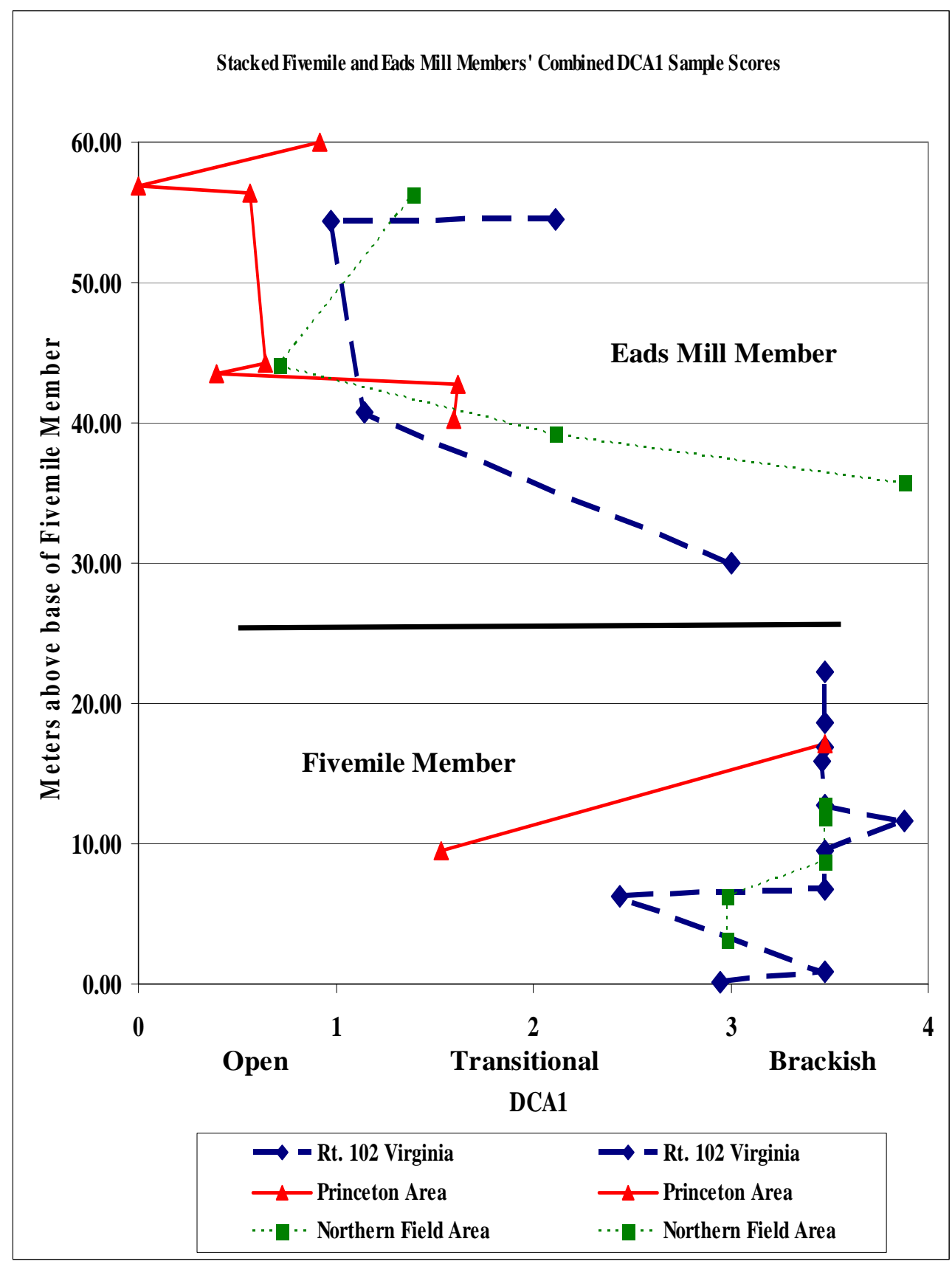

Figure 33. Chart showing stacked Fivemile and Eads Mill Member DCA1 sample scores. Rt 102 VA is a complete stratigraphic section containing both the Fivemile and Eads Mill Members. The Princeton area data is a compilation of the US Rt 460 Fivemile Member section and the Eads Mill Member Bluestone River Bridge locality. The Northern Field Area is a compilation of the Fivemile Member Elk Knob outcrop and the Eads Mill Member Interstate 64 locality. A separating interval marked as a horizontal line between the Fivemile and Eads Mill Members was applied to each graph to represent the terrestrial deposits between the two members. Each section demonstrates that the Fivemile Member was deposited in brackish to transitional marine conditions, and that a transgression near the base of the Eads Mill Member initiated a change from the brackish to transitional marine into an open marine environment. 
The Fivemile Member, which occurs below the Eads Mill Member and is separated from it by non-marine facies, is dominated by brackish marine taxa who lived in a nearshore marine environment with widely fluctuating salinities caused by freshwater mixing (Hudson et al., 1995). It is typified by the presence of ostracods, Lingula, and the epifaunal bivalve Modiolus (Table 6, Part 2). It also contains fewer numbers of transitional marine taxa such as gastropods and the straight shelled nautiloid Reticycloceras, which could tolerate a wide range of salinities and allow them to inhabit both marginal and open marine conditions. However, the Fivemile Member contains only one sample (B35, Figures 27, 30) that represents an open marine environment, much unlike the overlying Eads Mill Member that was predominantly deposited in open marine conditions (Figure 33).

Overall, a small rise in sea level initiated the deposition of the Fivemile Member atop the underlying terrestrial deposits. Predominantly brackish marine conditions persisted throughout deposition of the Fivemile Member as sea level fluctuated slightly, but retained highly positive DCA1 values (Figure 33). The top of the Fivemile Member is marked by a regression and a transition back to terrestrial facies. A transgression marks the beginning of the Eads Mill Member from the underlying terrestrial deposits separating the Fivemile and Eads Mill Members. The Eads Mill Member transgression was more extensive than that of the Fivemile Member. The lower portion of the Eads Mill Member marks a transition from brackish marine into fully open marine conditions, signified by the change from brackish marine taxa such as cephalopods and bivalves, to brachiopod and other stenohaline taxa present in the open marine environment. The lower 
limestone marks the maximum transgressive surface of the initial sea level rise. Above it, a regression brought mud into the basin, resulting in the formation of a thick shale. The upper limestone unit signifies the second maximum transgressive surface that was formed due to a small sea level rise after shale deposition. A regression at the top of the Eads Mill Member shifted the facies back through the transitional marine environment and finally formed terrestrial deposits at the top of the member. The transgressive/ regressive cycle that formed the Eads Mill Member was much more laterally extensive than that of the Fivemile Member, as indicated by the dominance of stenohaline taxa.

\subsection{Synthesis}

Paleoecology of the Fivemile and Eads Mill members was controlled by the proximity of the shoreline (Beuthin and Blake, 2004), which directly influenced water depth, the resulting salinity, and perhaps water turbidity (Carney and Smosna, 1989; Fursich, 1993). Taxa contained within each member thus directly represent the paleosalinity within the depositional environment. Whereas the Fivemile and Eads Mill members share 20 of the 36 genera identified within this study, each member has a distinct generic assemblage that defines the overall environmental conditions present during deposition. The Fivemile Member is dominated by brackish marine taxa, with fewer samples indicating a transitional environment. In contrast, the Eads Mill Member is dominated by open marine taxa, with transitional and brackish conditions present at the beginning of the transgression and the end of the regression. Thus these two marine members, while sharing many of the same taxa, represent two distinct depositional 
environments with taxonomic compositions that represent differences in their paleosalinity.

\section{1 Conclusions}

Salinity and proximity to shoreline were the principal environmental factors controlling the taxonomic composition of each sampled unit within the Eads Mill Member. Brackish and transitional marine taxa at the base and top of the Eads Mill Member mark the initial transgression and the end of regression, during which time salinity was lower due to the mixing of freshwater supplied by local fluvial sources. Turbidity and amount of clastic material would also have been higher in the marginal marine than in the open marine environment, though their affects on taxonomic composition were less than that of salinity. The two limestones near the middle of the Eads Mill Member contain brachiopods and other stenohaline taxa that signify that the transgression continued until open marine conditions with normal ocean salinities were reached (Figure 26). The formation of the two correlative limestones (Figures 14), mark the maximum transgressive surfaces and signify that open marine conditions with a cessation of clastic influx were experienced in the middle sections of all Eads Mill Member outrops. Thus the salinity tolerance of each guild identified within the Eads Mill Member controlled its occurrence within the stratigraphic sequence.

Taxa within Eads Mill Member of the upper Hinton Formation compare most closely to the Reynolds Limestone of the Bluefield Formation (Kammer and Lake, 2001), 
the Avis Limestone of the Hinton Formation (Henry and Gordon, 1992), and the Greenbrier Limestone Group (Carney and Smosna, 1989; Wynn, 2005) of the Upper Mississippian in the Appalachian Basin. All four units contain a diverse assemblage of open marine taxa dominated by brachiopods, crinoids, fenestrate bryozoans and some rugose corals. Conversely, the taxonomic composition of the Fivemile Member of the upper Hinton Formation is similar to the Bickett Shale of the Bluefield Formation (Kammer and Lake, 2001). Both were deposited in brackish marine conditions and contain representative euryhaline taxa such as bivalves and gastropods. Salinity tolerance is interpreted to be the control on distribution of invertebrate fauna within Upper Mississippian strata in the Appalachian Basin. 


\section{References}

Bailey, A.M., Roberts, H.H. and Blackson, J.H. 1998, Early diagenetic minerals and variables influencing their distributions in two long cores (> $40 \mathrm{~m}$ ), Mississippi River delta plain, Journal of Sedimentary Research, vol. 68, no. 1, p. 185-197.

Bambach, R.K., 1983, Ecospace utilization and guilds in marine communities through the Phanerozoic, in Tevesz, M.J.S. and McCall, P.L., eds, Biotic Interactions in recent and Fossil Benthic Communities: Plenum Press, New York, p. 719-746.

Beuthin, J.D. and Blake, B.M.,Jr., 2002, Scrutiny of a global climate model for Upper Mississippian depositional sequences in the Central Appalachian foreland basin, U.S.A, Journal of Geology, vol. 110, no. 6, p. 739-747.

Beuthin, J. and Blake, M.B.Jr., 2004, Revised stratigraphy and nomenclature from the upper Hinton Formation (Upper Mississippian) based on recognition of regional marine zones, southern West Virginia, Southeastern Geology, vol. 42, no. 3, p. 165167.

Brezinski, D.K. 1989, Upper Mississippian depositional patterns in the north-central Appalachian Basin, and their implications to Chesterian hierarchal stratigraphy, Southeastern Geology, vol. 30, no. 1, p. 1-23.

Carney, C. \& Smosna, R. 1989, Carbonate deposition in a shallow marine gulf, the Mississippian Greenbrier Limestone of the Central Appalachian Basin, Southeastern Geology, vol. 30, no. 1, pp. 25-48.

Cecil, C.B., 1990, Paleoclimate controls on stratigraphic repetition of chemical and siliciclastic rocks, Geology, vol. 18, p. 533-536.

Chang, Y.-M., 1967, Accuracy of fossil percentage estimation, Journal of Paleontology, v. 41, p. $500-502$

Englund, K.J., 1968, Geologic map of the Bramwell quadrangle, West Virginia-Virginia: U.S. Geological Survey Map GQ-745, scale 1:24000.

Englund, K.J., Gillespie, W.H., Johnson, P.L., Pfefferkorn, H.W., Rodgers, J., Bambach, R.K. and Gray, D.R. 1986, Depositional model for Upper Mississippian and Lower Pennsylvanian rocks of southwestern Virginia; The Lowry Volume; Studies in Appalachian geology, Memoir - Department of Geological Sciences, Virginia Polytechnic Institute and State University, vol. 3, p. 37-45. 
Ettensohn, F.R., Greb, S.F. and Chesnut, D. R.,Jr. (leader), 1998, Stop 8; the Little Stone Gap Limestone, Pride Shale interval; Geology of the Pound Gap roadcut, Letcher County, Kentucky, Annual Field Conference of the Kentucky Society of Professional Geologists, vol. 1998, p. 51-54.

Ettensohn, F.R., Greb, S.F., Chesnut, D.R.,Jr, Harris, D.C., Mason, C.E., Eble, C.F., Howell, P.D., Watson, A.E. and Johnson, W.K., 2002, Mississippian stratigraphy, depositional environments, and tectonic framework of the central Appalachian Basin, eastern Kentucky, U.S.A; Carboniferous and Permian of the world; XIV ICCP proceedings, Memoir - Canadian Society of Petroleum Geologists, vol. 19, p. 22-40.

Fursich, F.T., 1993, Paleoecology and evolution of Mesozoic salinity-controlled benthic macroinvertebrate associations, Lethaia, v. 26, p. 327-346

Gillespie, W.H., Clendening, J.A., and Pfefferkorn, H.W., 1978, Plant Fossils of West Virginia, West Virginia Geological and Economic Survey, Morgantown, WV, 172 p.

Greb, S.F. and Chesnut, D. R.,Jr, (leader) 1998, Stop 9; pedogenic features in the lower part of the Pennington Formation; Geology of the Pound Gap roadcut, Letcher County, Kentucky, Annual Field Conference of the Kentucky Society of Professional Geologists, vol. 1998, p. 55-56.

Gordon, M., Jr., 1964, Carboniferous Cephalopods of Arkansas, Geological Survey Professional Paper 460, p. 116-119.

Hammer, O., Harper, D.A.T., Ryan, P.D., 2007, PAST: PAleontological STatistics Software, Retrieved February 1, 2007, from http://folk.uio.no/ohammer/past/index.html

Henry, T.W., and Gordon, M. Jr., 1979, Late Devonian through Early Permian(?) invertebrate faunas in the proposed Pennsylvanian system stratotype area., AGI Selected Guidebook Series, no. 1, p. 97-103.

Henry, T.W., and Gordon, M. Jr., 1992, Middle and Upper Chesterian brachiopod biostratigraphy, Eastern Appalachians, Virginia and West Virginia. In: Sutherland, P.K. and Manger, W.L., eds., Recent advances in Middle Carboniferous stratigraphy- a symposium, Oklahoma Geological Survey Circular 94, p. 1-21.

Hoare, R.D., 1993, Mississippian (Chesterian) bivalves from the Pennsylvanian stratotype area in West Virginia and Virginia, Journal of Paleontology, vol. 67, p. 374-396. 
Hudson, J.D., Clements, R.G., Riding, J.B., Wakefield, M.I., and Walton, W., 1995, Jurassic paleosalinities and brackish-water communities- a case study, Palaios, v. 10 , p. 392-407

Kammer, T.W., and Lake, A.M., 2001, Salinity ranges of Late Mississippian invertebrates of the central Appalachian Basin, Southeastern Geology, vol. 40, no. 1, p. 99-116.

Klein, G.D. and Kupperman, J.B., 1992, Pennsylvanian cyclothems; methods of distinguishing tectonically induced changes in sea level from climatically induced changes, Geological Society of America Bulletin, vol. 104, no. 2, p. 166-175.

Lebold, J.G. and Kammer, T.W., 2006, Gradient analysis of faunal distributions associated with rapid transgression and low accommodation space in a Late Pennsylvanian marine embayment: Biofacies of the Ames Member (Glenshaw Formation, Conemaugh Group) in the northern Appalachian Basin, USA, Palaeogeography, Palaeoclimatology, Palaeoecology, vol. 231, p. 291-314

Maynard, J.P., Eriksson, K.A., and Law, R.D., 2006, The upper Mississippian Bluefield Formation in the Central Appalachian basin: A hierarchical sequence-stratigraphic record of a greenhouse to icehouse transition, Sedimentary Geology, vol.192, p. 99122

McDowell, R.C. and Schultz, A.P., 1990, Structural and stratigraphic framework of the Giles County area, a part of the Appalachian basin of Virginia and West Virginia, U.S. Geological Survey Bulletin, 1839E, 24 p.

McKinney, 1972, Nonfenestrate Ectoprocta (Bryozoa) of the Bangor Limestone (Chester) of Alabama, Geological Survey of Alabama Bulletin, vol. 98, 144 p.

Miller, D.J. and Eriksson, K.A., 1999, Linked sequence development and global climate change; the Upper Mississippian record in the Appalachian Basin, Geology (Boulder), vol. 27, no. 1, p. 35-38.

Miller, D.J. and Eriksson, K.A., 2000, Sequence stratigraphy of Upper Mississippian strata in the central Appalachians; a record of glacioeustasy and tectonoeustasy in a foreland basin setting, AAPG Bulletin, vol. 84, no. 2, p. 210-233.

Miller, R.L. 1964, The Little Stone Gap Member of the Hinton Formation (Mississippian) in Southwest Virginia, USGS professional paper 501-B, p. B39-B42

Moore, R.C. (ed.), 1959, Treatise on Invertebrate Paleontology; Part O: Arthorpoda 1, The University of Kansas Press, 560 p. 
Moore, R.C., and Pitrat, C. W. (eds.), 1960, Treatise on Invertebrate Paleontology; Part I: Mollusca 1, The University of Kansas Press, 351 p.

Moore, R.C. (ed.), 1964, Treatise on Invertebrate Paleontology; Part K: Mollusca 3, The University of Kansas Press, 519 p.

Moore, R.C. (ed.), 1965, Treatise on Invertebrate Paleontology; Part H: Brachiopoda, The University of Kansas Press, vol. 1\&2, 927 p.

Moore, R.C., and Teichert, C. (eds.), 1969, Treatise on Invertebrate Paleontology; Part N: Mollusca 6, The University of Kansas Press, vol. 1\&2, 952 p.

Muir-Wood, H., and Cooper, G.A., 1960, Morphology, classification and life habits of the Productoidea (Brachiopoda), The Geological Society of America Memoir, vol. 81, 447 p.

Postma, D. 1982, Pyrite and siderite formation in brackish and freshwater swamp sediments, American Journal of Science, vol. 282, no. 8, p. 1151-1183.

Reger, D.B., 1926, Mercer, Monroe, and Summers Counties: West Virginia Geological Survey County Reports, 963 p.

Rohlf, J.F., 1998, Numerical taxonomy and multivariate analysis system user guide, Applied Biostatistics, Exeter Software, Setauket, NY, 31 p.

Scarponi, D., and Kowalewski, M., 2004, Statigraphic paleoecology: Bathymetric signatures ad sequence overprint of mollusk associations from upper Quaternary sequences of the Po Plain, Italy, Geology, vol. 32, no. 11, p. 989-992

Scotese, C., 1986, Atlas of Paleozoic basemaps: Paleoceanographic mapping project: Austin, University of Texas Institute for Geophysics, Technical Report 66, p. 1-23

Smith, L.B., and Read, J.F., 2000, Rapid onset of Late Paleozoic glaciation on Gondwana: evidence from Upper Mississippian strata of the Midcontinent, United States, Geology, vol. 28, p. 279-282.

Smith, L.B., Al-Tawil, A. and Read, J.F., 2001, High-resolution sequence stratigraphic setting of Mississippian eolianites, Appalachian and Illinois basins; Modern and ancient carbonate eolianites; sedimentology, sequence stratigraphy, and diagenesis, Special Publication - Society for Sedimentary Geology, vol. 71, p. 167-181.

Thein, M.L. and Nitecki, M.H., 1974, Chesterian (Upper Mississippian) Gastropoda of the Illinois Basin, Fieldiana Geology, vol. 34, p. 1-240 
Wynn, T.C. (ed), 2005, Geologic Field Guide to Sequence Stratigraphic Framework of Big Lime Reservoirs of West Virginia, AAPG Eastern Section Meeting Field Trip, September 16-18, 2005 


\section{Appendix 1}

WVGS Fieldbook Numbers for Eads Mill Member Sections

VA Rt 102: 295-001

Eads Mill Road: 295-057

Pipestem Creek: 309-061

I-64: 309-058 


\section{Appendix 2}

\section{Taxa Characteristics Used in Identification}

Brachiopods: Page numbers from Moore (1965) listed in parentheses Anthracospirifer (H 704) - Its hinge line is transverse and nearly equal to maximum width, and it has a moderate number of bifurcating lateral plications. The fold and sulcus is distinct.

Cleiothyridina (H 662) - It has a transversely sub-oval shell that is nearly biconvex. Distinct fold and sulcus are developed anteriorly.

Composita (H 662) - Has a characteristically smooth, biconvex shell with well developed fold and sulcus. Growth lines are nearly perpendicular to the hinge.

Diaphragmus (H 484) - Is medium sized with medium to thick costellae extending the length of the pedicle valve. A few scattered spine bases noted on some specimens.

Eumetria (H 651) - Has slightly oval to elongated costate shells. No fold or sulcus noted.

Flexaria (H 490) - Shell is a rounded triangle in outline. Pedicle valve has irregular to elongate costae with short overlapping spine ridges.

Fluctuaria (H 501) - Is a small shell that is sub-circular in outline and is broadest anteriorly. Pedicle valve has fine costellae and is strongly rugose over the entire valve.

Inflatia (H 482) - Is a medium sized specimen with highly convex pedicle valve that contains small, rounded costae that converge at the sulcus.

Lingula (H 263) - Has an elongated oval outline with slightly convex valves. Concentric growth lines are sub-parallel to hinge and extend anteriorly.

Orthotetes (H 409) - Medium to large size with a sub-rounded outline whose hinge extends nearly its entire width. Has numerous fine costellae that radiate from its umbo.

Ovatia (H 503) - Has an elongate shell with highly convex pedicle valve. It contains numerous fine costellae extending the length of the pedicle valve.

Punctospirifer (H 714) - Is small to medium sized similar to Anthracospirifer. Has strong lateral plications, imbricate growth lamellae, and is punctuate, from which it derives its name. 
Torynifer (H 724) - A small, sub-rounded shell with a prominent umbo. No distinct fold and sulcus noted, and both valves lack ornamentation.

Bivalves: Page numbers from Moore \& Teichert (1969) listed in parentheses Aviculopecten (N 336) - Has fine radial ornamentation propagating from its beak. Its hinge extends nearly the width of the shell, below which is a deep byssal notch.

Cardiomorpha (N 818) - Similar in shape to Edmondia, but with a much more prominent beak and umbo. It has a smooth exterior with very fine growth lines.

Edmondia (N 818) - Ovoid to elliptically elongate shell, with a small beak located one-third behind its anterior margin. Its exterior has irregular concentric growth lines.

Ectogrammysia (N 819) - Has an ovoid shell with thick radial ribs.

Modiolus (N 278) - An oval, elongated shell with the beak behind the anterior end. The exterior is smooth with fine concentric growth lines.

Nuculopsis (N 231) - It is a very inequilateral shell with fine concentric growth lines and a curved beak.

Paleyoldia (N 237) - Has a compressed, trigonally rounded shell with numerous fine concentric growth lines.

Phestia (N 238) - It has a compressed anteriorly oblique shell with numerous fine concentric growth lines. Inside, the hinge contains chevron shaped tooth and socket holes.

Schizodus (N 475) - Has an inequilateral, trigonally ovate shell with a pronounced beak and fine concentric growth lines.

Septimyalina (N 291) - It has a slender elongated shell with and extended beak and a smooth exterior. A distinct linear ridge extends along one edge of the shell and disappears near its anterior end.

Gastropods: Page numbers from Moore \& Pitrat (1960) listed in parentheses Bellerophon (I 182) - A tightly whorled specimen in youth whose profile flattens with maturity. A convexly elevated selenizone comprises about 10 percent of the width. Growth lines, which become more prominent towards the aperture are closely spaced and curved sharply towards the selenizone. 
Euphemites (I 178) - Whorl profile is evenly rounded in young specimens.

Selenizone comprises 25 percent of the width. Evenly spaced lirae are continuous along the length of the whorl to the shell aperture.

Ianthinopsis (I 320) - It has a wide, globular form with a small pointed apex. Some faint spiral ridges may be noted on an otherwise plain exterior.

Knightites (I 184) - Whorl profile is sub-triangular at maturity and grades backward into a more evenly rounded shape. Has a prominent selenizone that is 25 percent of the shell width and is convexly elevated, resembling a keel near the aperture of mature specimens. Closely spaced growth lines that curve in towards the selenizone are crossed nearly perpendicular by fine lirae.

Naticopsis (I 276) - Has an extremely wide body whorl with a slightly elevated spire. Its body whorl is relatively well rounded.

Cephalopods: Page numbers from Moore (1964) listed in parentheses

Reticycloceras (K 250) - A straight shelled nautiloid with coarse, evenly spaced transverse ribbing extending the length of the shell. The siphuncle is centrally located.

\section{Trilobites: Page numbers from Moore (1959) listed in parentheses}

Paladin (O 401) - Its glabella is nearly parallel sided, and its eyes are large in size and are posteriorly located. The pygidium has a well defined border.

\section{Bryzoans}

Archimedes - A fenestrate with fans the spread outward from a central screwshaped spiral. The fans have a fine cross-crossed mesh pattern in which the individual organisms lived.

Encrusting - A homogenous pattern of very fine $(<1 \mathrm{~mm})$ pits or borings on the exterior of shell material.

\section{Paraconularid}

Paraconularia - A cnidarian with coarse, wavy ribs that extend transversely across its body. It is narrow where it attaches to the substrate, and forms a widening taper upwards. 


\section{Crinoids}

Crinoid Columnals - Individual columnals appear as small discs, having radial symmetry and a centrally located hole for its water vascular system.

\section{Corals}

Solitary Rugose Corals - Medium (1-2 inch) specimens have a tapered horn shape, a slightly rugose exterior, and have radial symmetry.

\section{Ostracods}

Ostracods - Very small (1 mm) flat, rounded specimens preserved in high abundance. 